\title{
Freedom of Expression and Hate Speech in Ethiopia: Observations
}

\section{Abstract}

Aron Degol * \& Bebizuh Mulugeta**

Freedom of expression is one of the human rights enshrined under International human right instruments. However, hate speech in the course of exercising this right has the potential to pose threats on the peace and security of nations and wellbeing of individuals. This has brought about arguments in favor of limitations to expression and against the limitations owing to unintended adverse impact of such limitations in the exercise of freedom of expression. In the Ethiopian case, 'Hate Speech and Disinformation Prevention and Suppression Proclamation No. 1185/2020' has been enacted. The Proclamation indicates prohibited acts of hate speech and its exceptions. In particular, the generic terms contained in the definition given to 'hate speech' need to be carefully examined. However, the implications of provisions that set exceptions to 'hate speech' in the new law have not yet been subject to adequate academic discourse. This article examines these issues. By consulting different international human rights instruments, experience of other countries and scholarly literature, the article examines the appropriateness, constitutionality and implications of the Proclamation on the right to freedom of expression. Moreover, it indicates potential challenges that the exceptions will pose on the process of implementing the Proclamation in real court cases.

\section{Key terms:}

Freedom of expression · Hate speech · FDRE Constitution · Ethiopia

\section{DOI http://dx.doi.org/10.4314/mlr.v15i1.7}

This article is licensed under a Creative Commons Attribution-

NonCommercial-NoDerivs (CC BY-NC-ND)

Received: 31 March 2021

Accepted: 3 July 2021

\section{Suggested citation:}

Aron Degol \& Bebizuh Mulugeta (2021), 'Freedom of Expression and Hate Speech in Ethiopia: Observations' (in Amharic), 15 Mizan Law Review 1: 195-226

\footnotetext{
- Aron Degol Habtu (LLB, LLM, MBA), Lecturer of Law and Management at St. Mary University

ORCID: https://orcid.org/0000-0002-6035-2222

** Bebizuh Mulugeta Menkir (LLB, LLM), Lecturer of Law, University of Gondar, School of Law, Former Public Prosecutor at Federal Attorney General's Office ORCID:https://orcid.org/0000-0002-5026-2282
} 


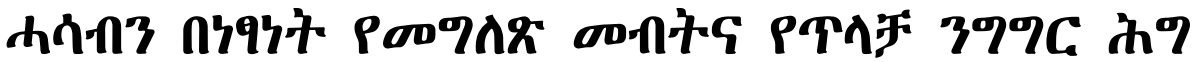

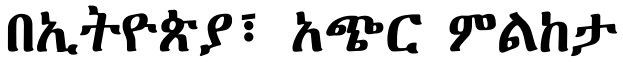

\section{hURC+ \&H市 (Abstract)}

\author{
久C.3
}

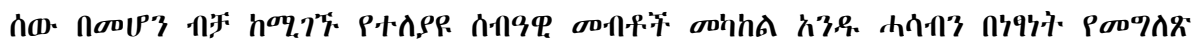

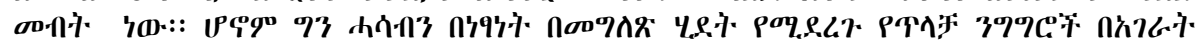

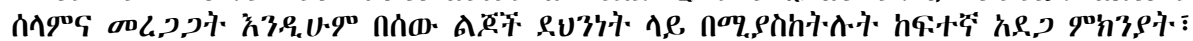

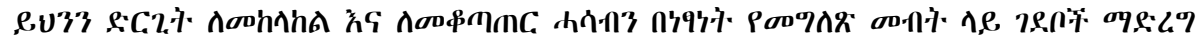

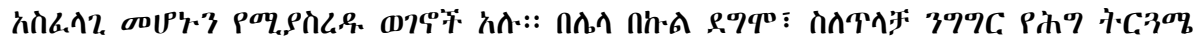

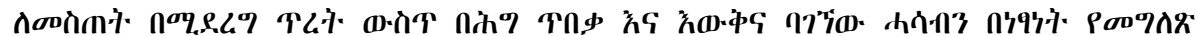

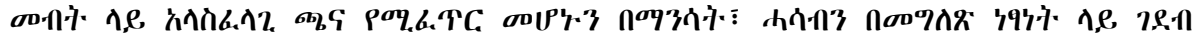

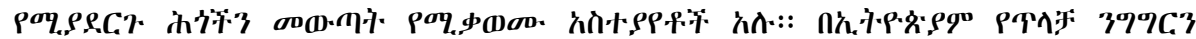

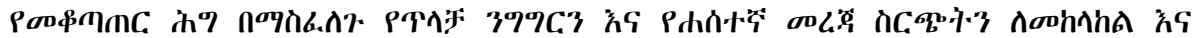

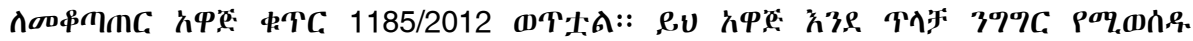
+996.

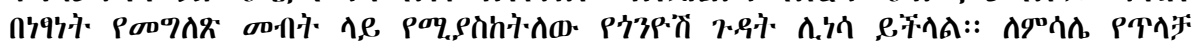

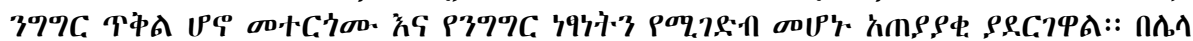

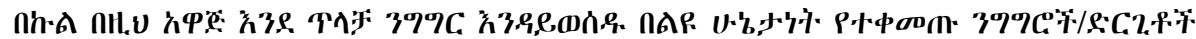

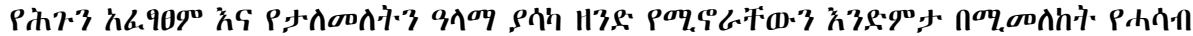

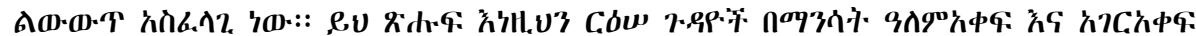

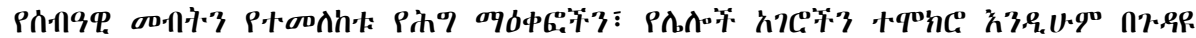

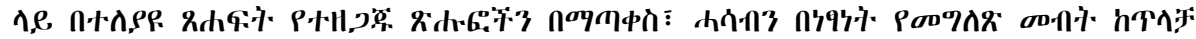

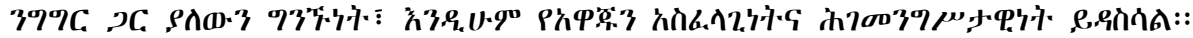

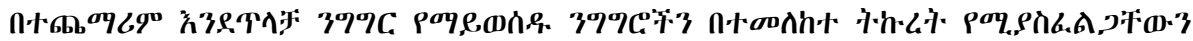

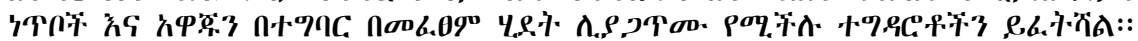

中ดร 虫方:-

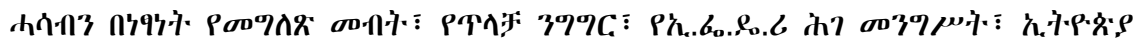

\section{1. $00 \% \mathrm{n} \rho$}

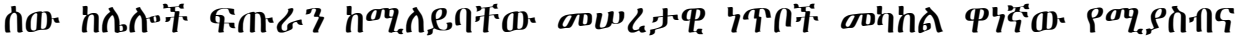

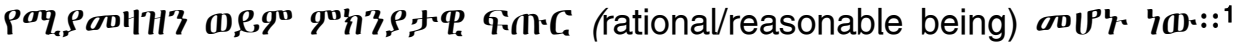

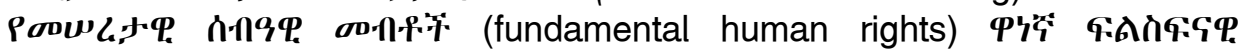

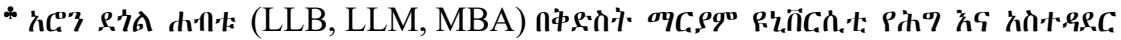

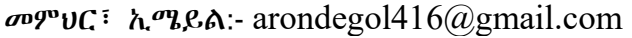
ORCID: https://orcid.org/0000-0002-6035-2222

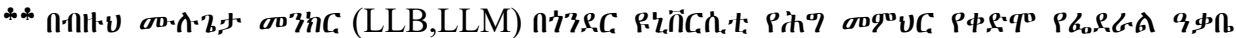
h\%: 久.

ORCID:https://orcid.org/0000-0002-5026-2282

${ }^{1}$ Korsgaard, Chrstine M., (2001), Rationality, a research paper presented to the national conference of philosophy and psychology, Delhi University, India, (Unpublished) p.1.

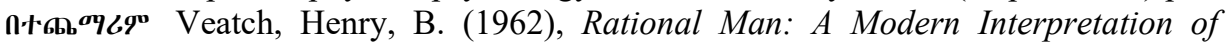
Aristotilian Ethics, Indiana University Press, USA, p. 17.
} 


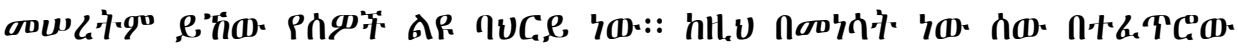

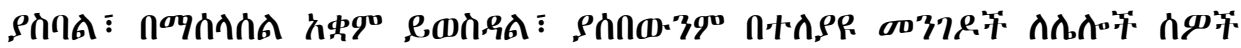

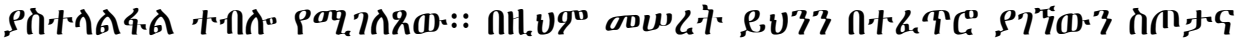

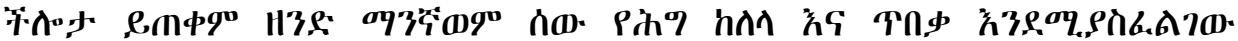

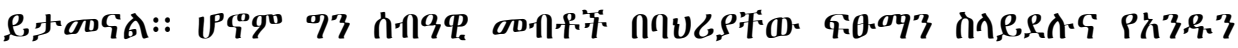

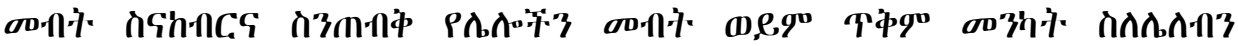

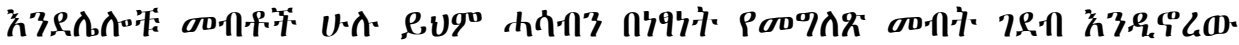
T.P.C.3A::

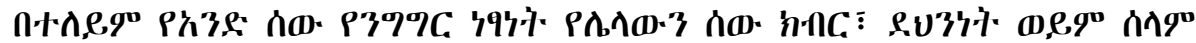

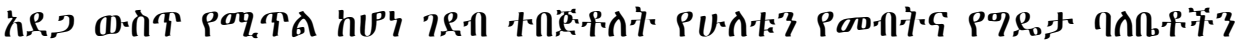

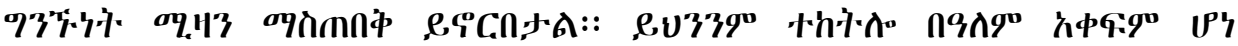
ПלาL.

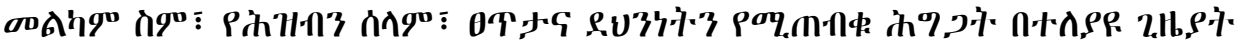

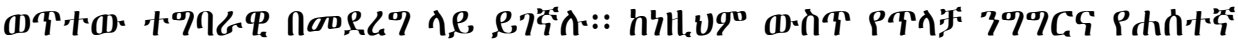

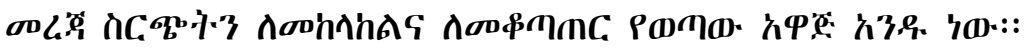

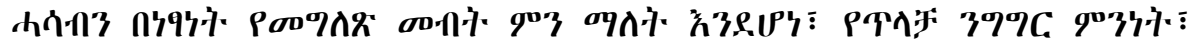

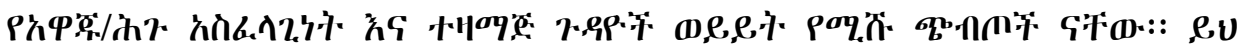

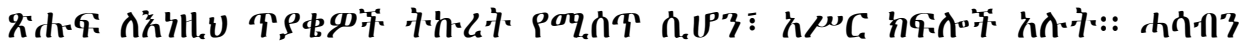

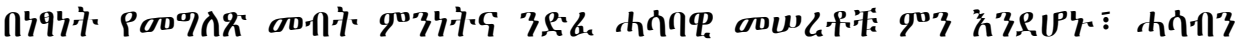

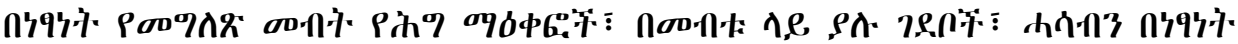

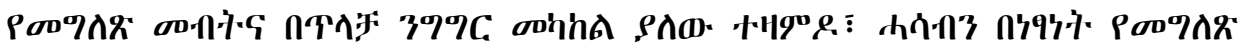

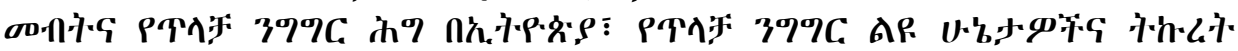

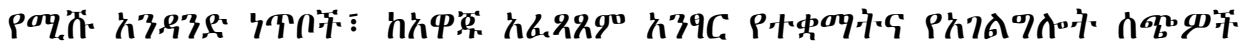
"3nbit

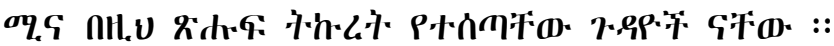

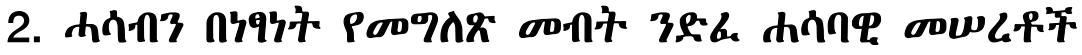

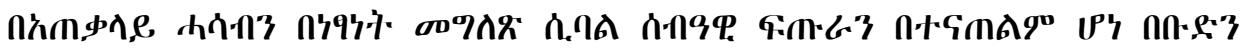

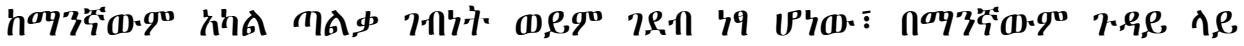

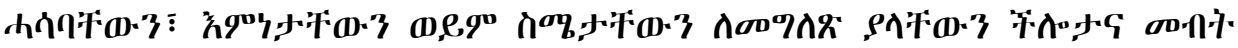
o9n'

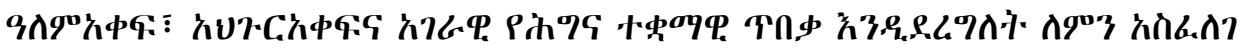

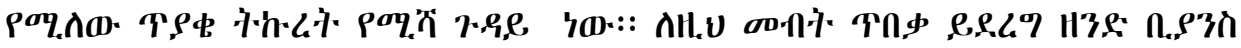

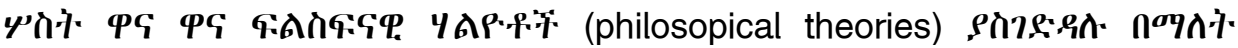

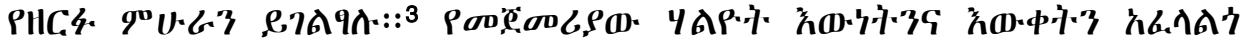

\footnotetext{
2 Baker, Edwin, C. (1989), Human Liberty and Freedom of speech, Oxford University Press, New York, p. 6 ! Liberties under the law, ABC-CLIO, Inc., St. Barbara, California, USA, p. 13 emant::: ${ }^{3}$ Gedion Timotheos (2010), 'Freedom of Expression in Ethiopia: The Jurisprudential

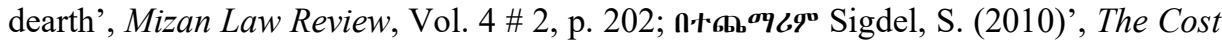
of Reputation: Freedom of Speech and Defmation, Unpublished (LLM Thesis), Central
} 


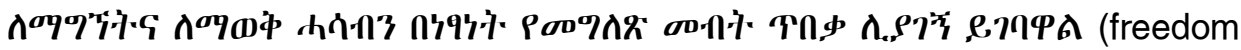
of expression as a prerequisite for the search for truth) $\boldsymbol{\Phi}, \mathbf{G O}$ (the truth

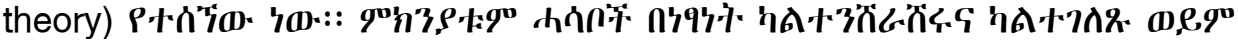

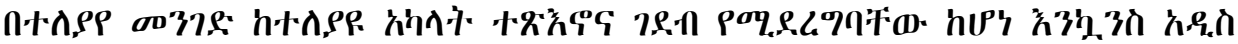

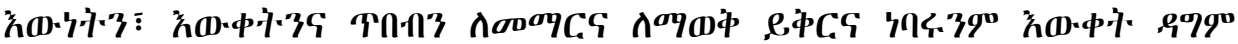

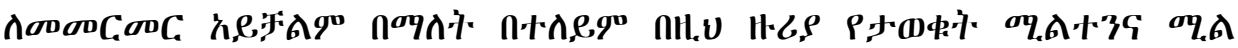

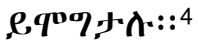

U. त卜 of expression as a prerequisite for self-governance $\boldsymbol{\omega}, \boldsymbol{e q}$ citizens'

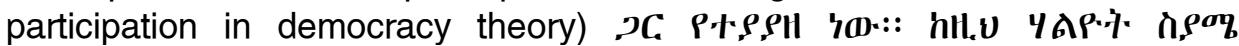

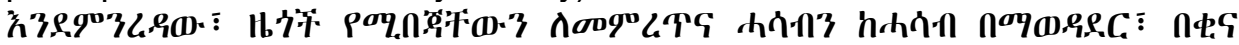

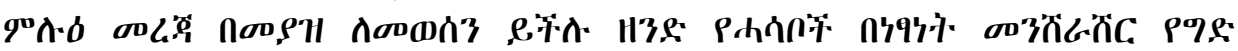

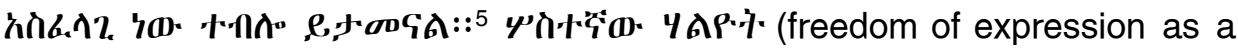
prerequisite for personal development $\boldsymbol{\omega}, \mathbf{Q q}$ self-fulfilment theory) Pl-in?

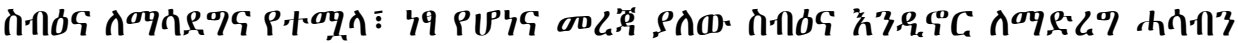

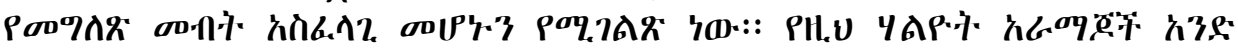

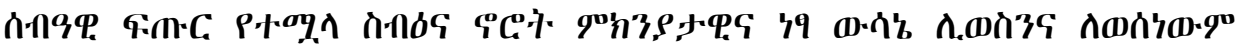

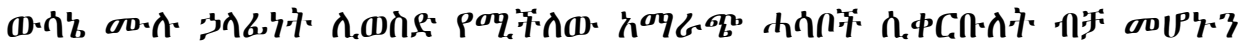
$\rho \Lambda \angle \cdot 9 \Lambda:: 6$

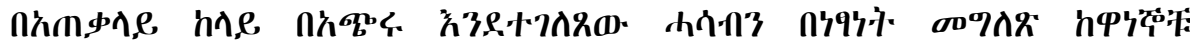

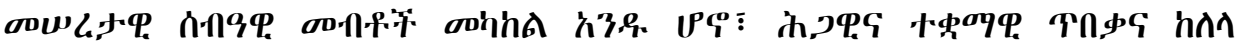

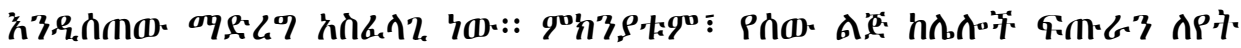

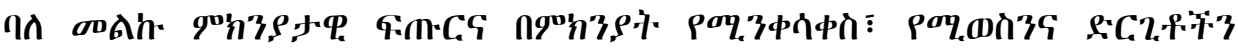

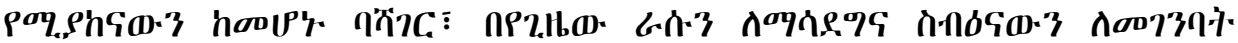

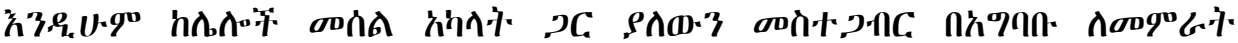

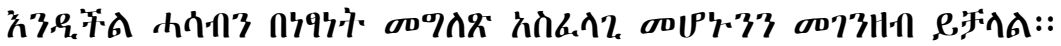

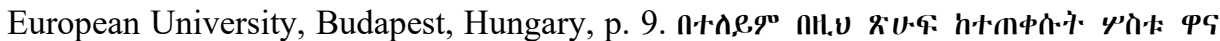

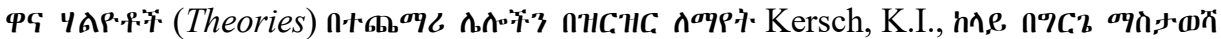

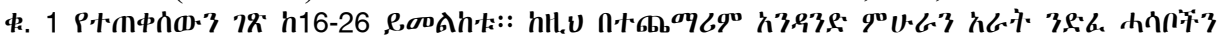

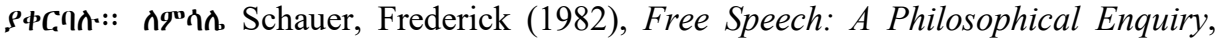

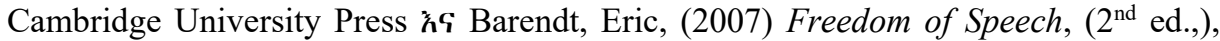
Oxford University Press, p. $21, \boldsymbol{l} \sigma \mathrm{on} h \mathrm{~h}$ ::

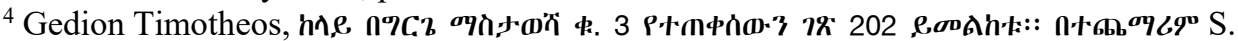
Sigdel, (2010), 7\% 11 : \$F Macleod, Christopher (Summer 2020 Edition), "John Stuart Mill", The Stanford Encyclopedia of Philosophy, Edward N. Zalta (ed.), URL =

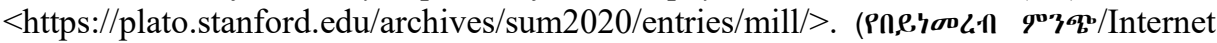

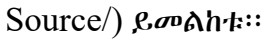

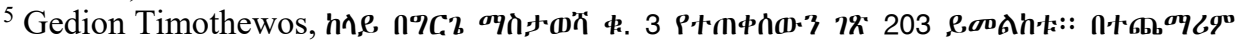

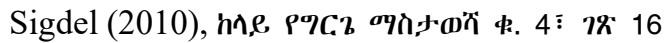

6 Thomas Scanlon (1972), A Theory of Freedom of Expression, Philosophy and Public

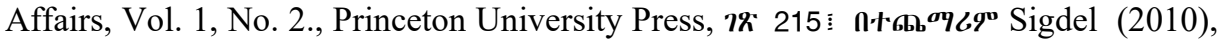

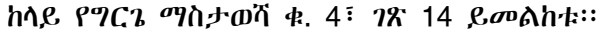




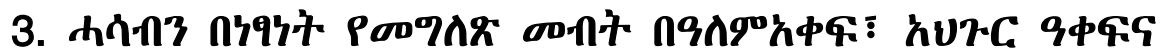

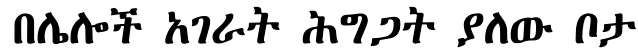

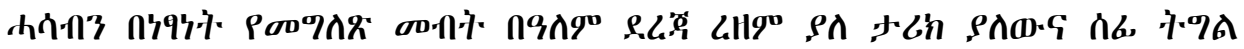

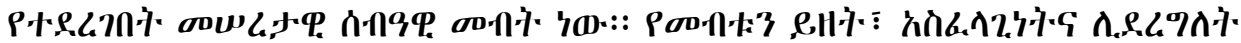

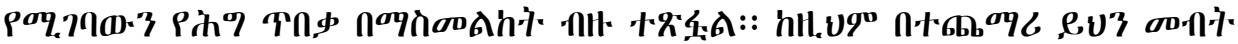

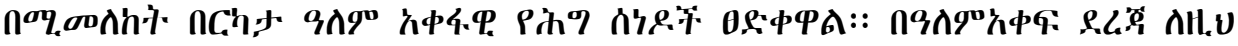

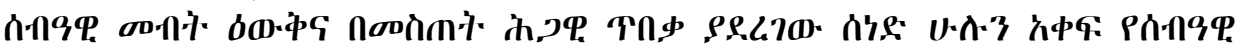

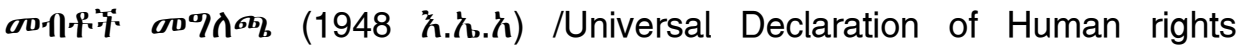

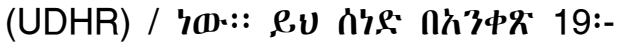

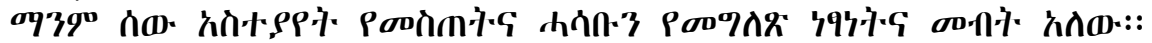

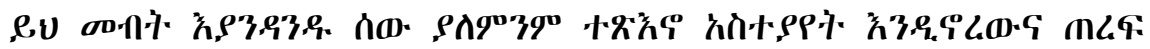

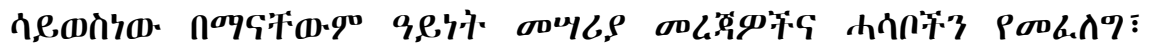

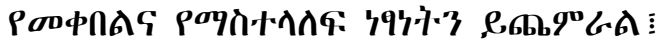

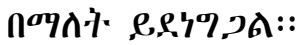

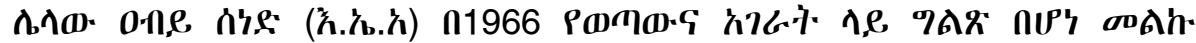

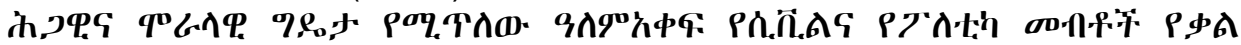

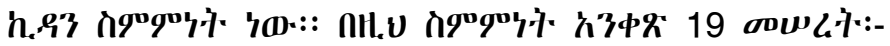

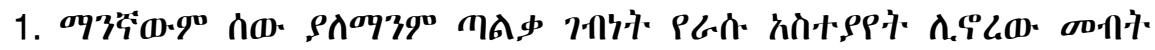
$\lambda \Lambda \sigma \cdot \vdots$

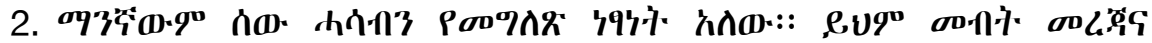

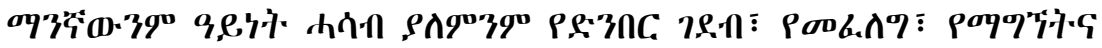

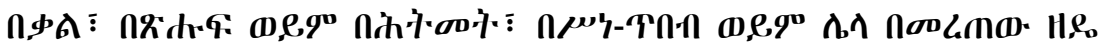

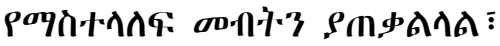

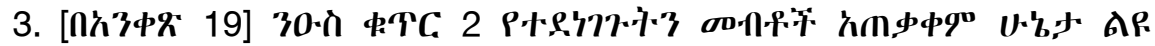
9

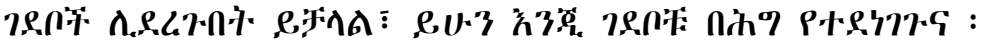

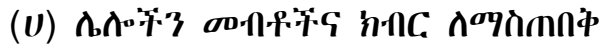

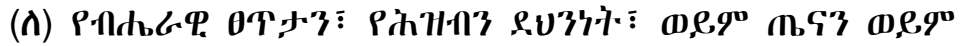

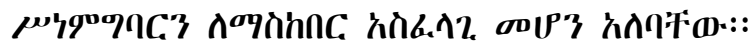

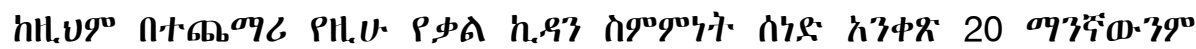

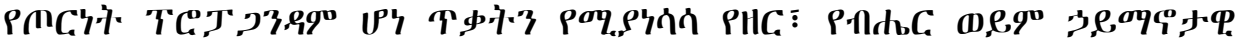

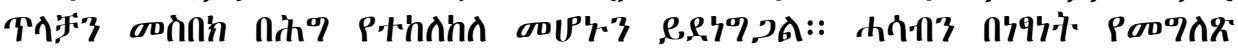

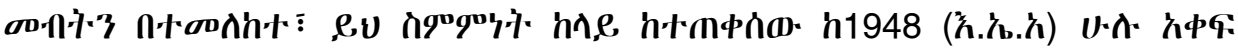

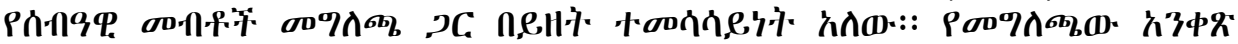
29(2) n,

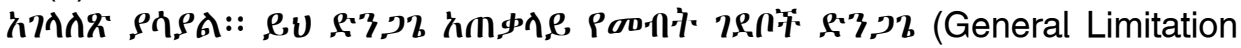

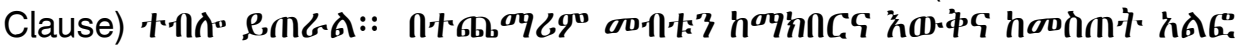

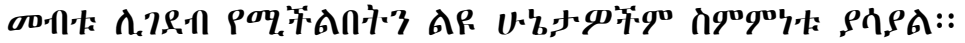

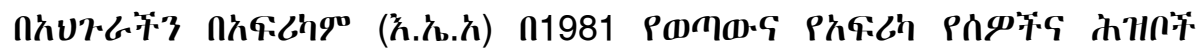
on-n年 FCAC: (African Charter on Human and People's Rights/ACHPR/)

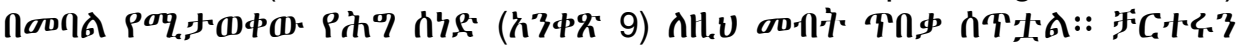
P小中nd h16. 


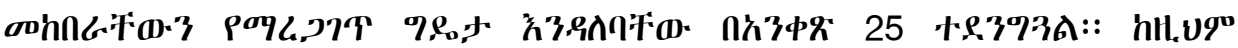

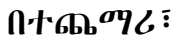

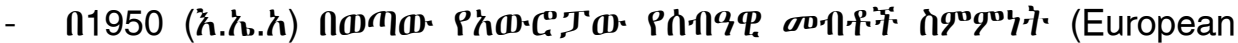
Convention for the Protection of Human Rights and Fundamental Freedoms/ECHR/

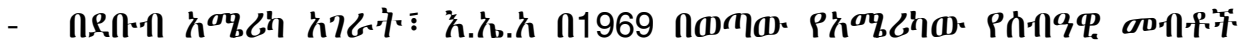

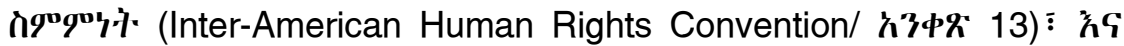

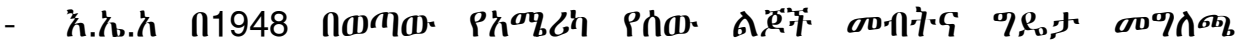
(American Declaration on the Rights of Man)

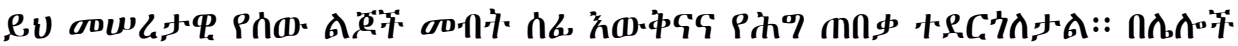

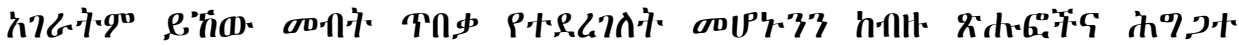
о039

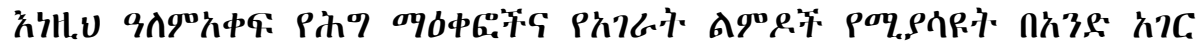
P.gnc oq'hl.

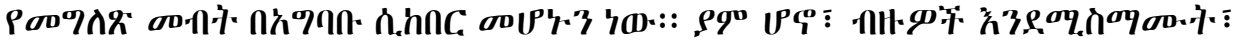

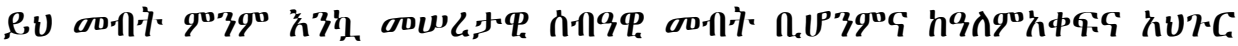

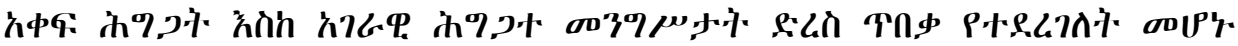

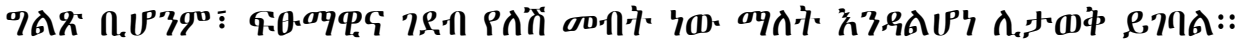

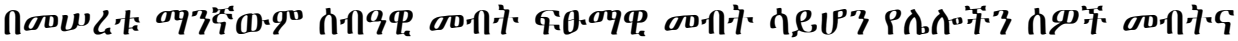

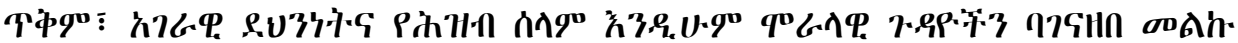

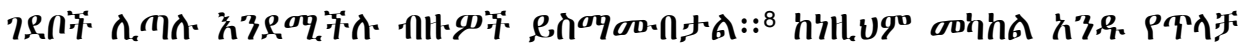

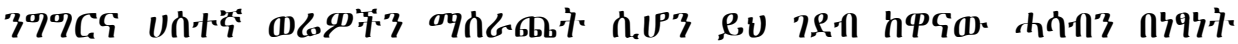

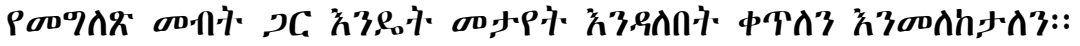

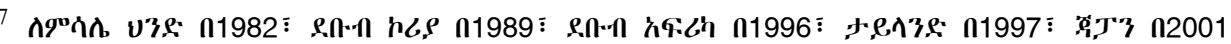

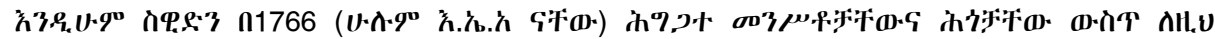

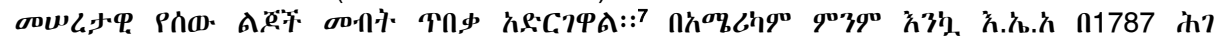

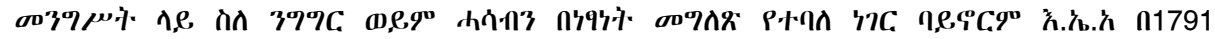

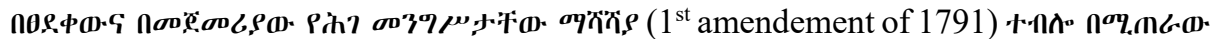

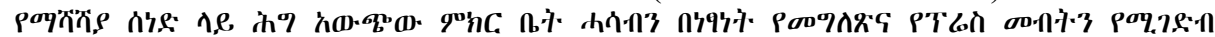

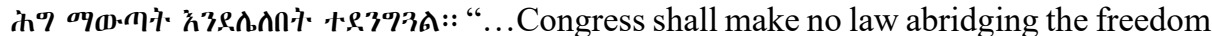

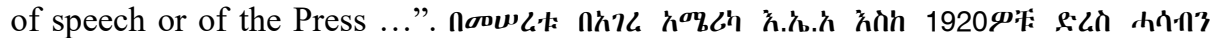

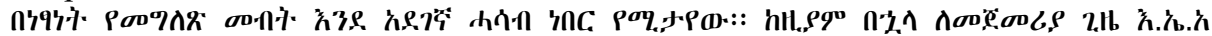

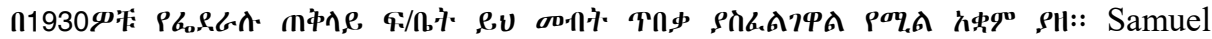
Walker, 'Hate Speech: The History of American Controversy', cited in Bell, Jeannine, (2009), 'Restraining the Heartless: Racsist speech and Minority Rights', Indiana Law

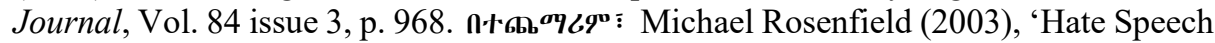
in Constitutional Jurisprudence: A Comparative Analysis', Cardozo Law Review, Vol.

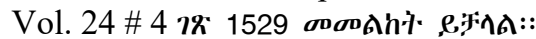

8 Wojciech Sadurski (1999), Freedom of Speech and its Limits, Kulwer Academic

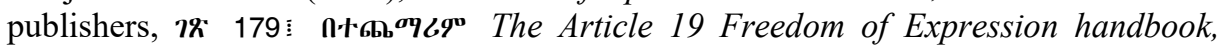
International and Comparative law, standards and procedures, (1993), $7 \% 114 \quad \mathbf{n G}$ Cram, Ian, (2006), Contested words: Legal Restrictions on freedom of speech in Liberal

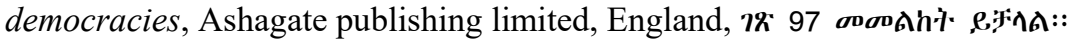




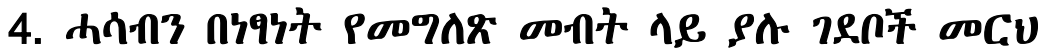

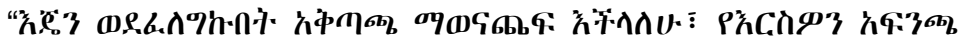

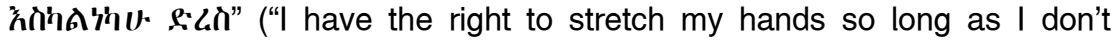
touch your nose.")

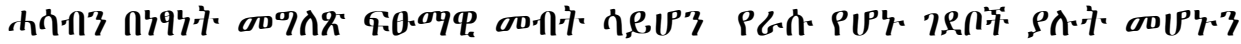

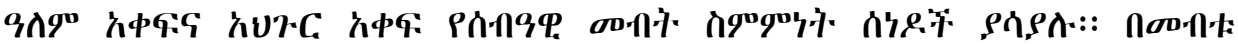

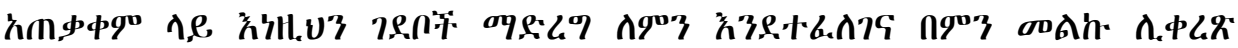

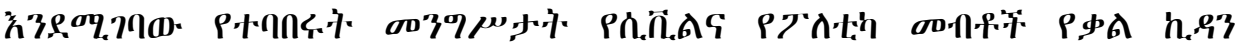

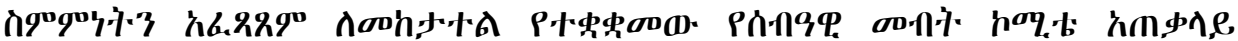

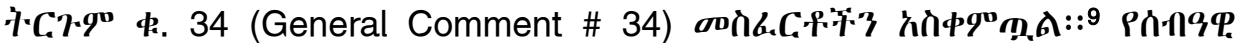

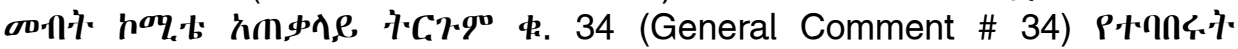

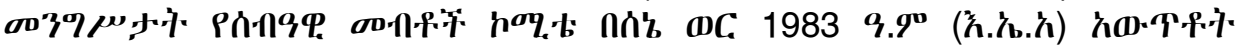

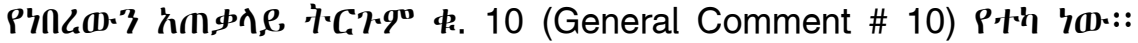

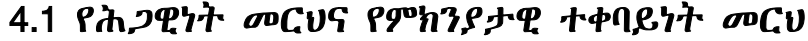

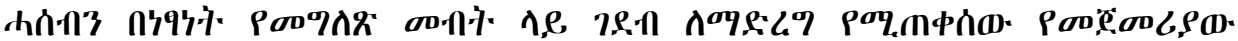

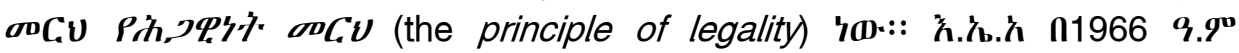

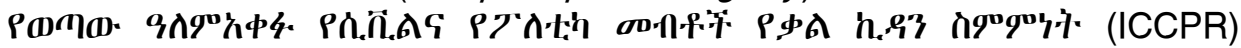

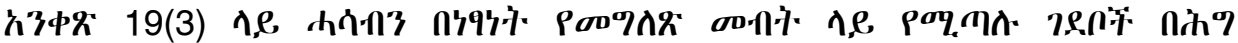

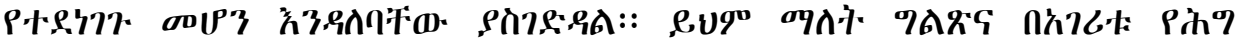

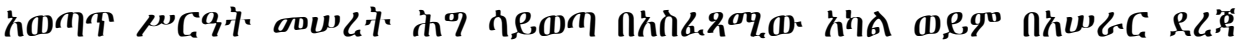

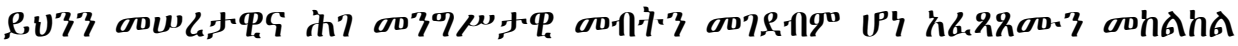

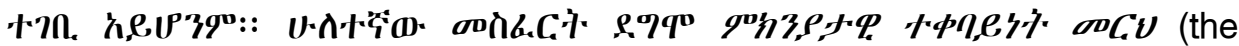

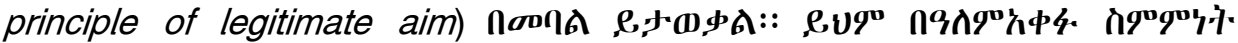

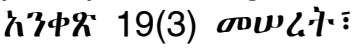

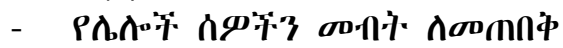

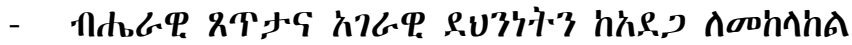

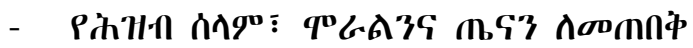

7.

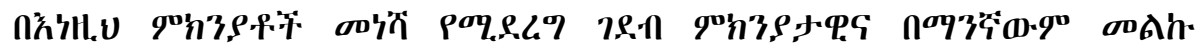

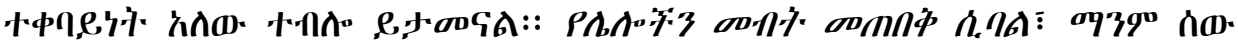

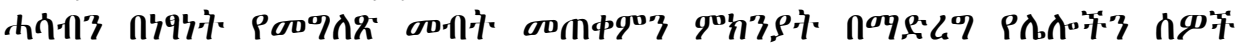

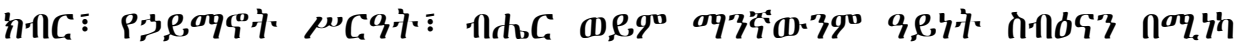

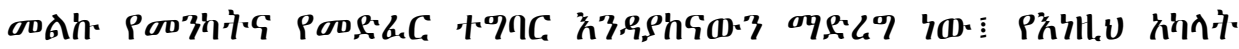

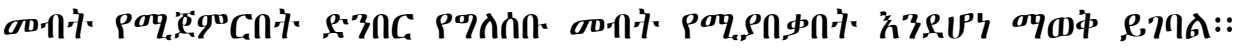

\footnotetext{
${ }^{9}$ Human Rights Committee, General Comment \# 34: Freedom of Expression (Art. 19) 29/06/83, Para. 4. ก+ณ\% Yonas Birmeta, (2008), 'Freedom of Expression and Crimes Against Honor Under Ethiopian Law: An Assessement of their compatability' in Girmachew A. and Sisay A. (Eds), 'The Constituional Protection of Human rights in Ethiopia Chalenges and Prospects', Ethiopian Human Rights Law Series, Vol. 2, AAU, Faculty of Law $7 \% 106$
} 


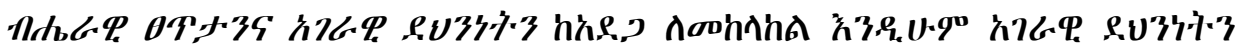

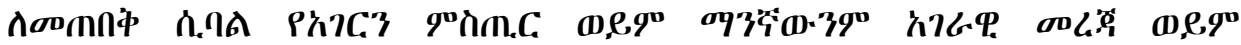

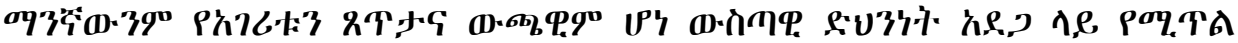

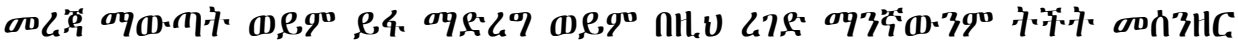

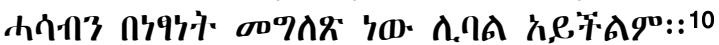

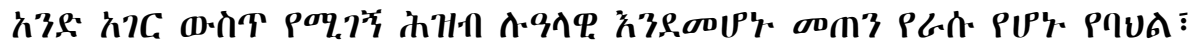

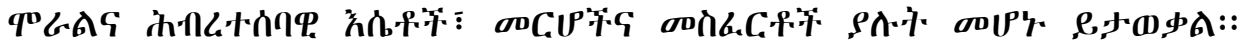

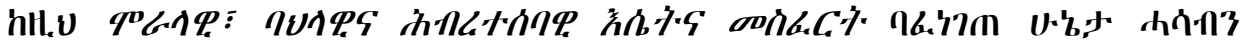

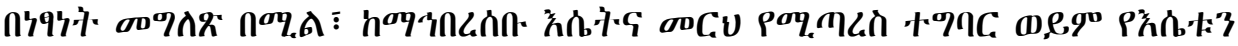

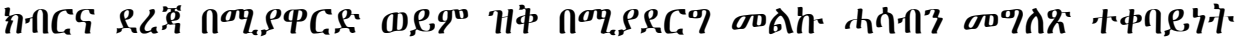
h,eqLad.90::

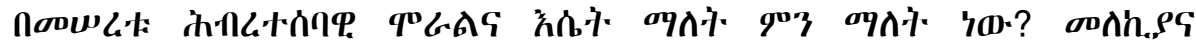

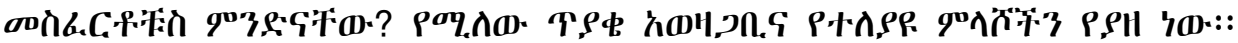

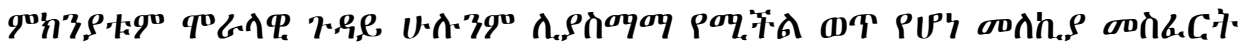

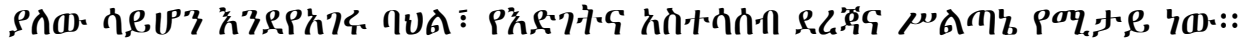

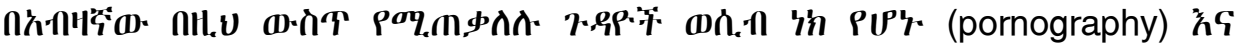

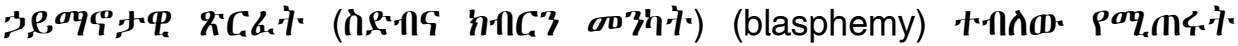

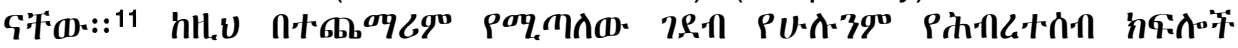

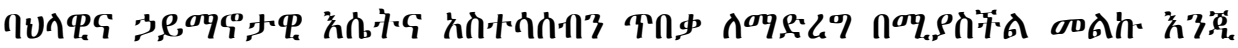

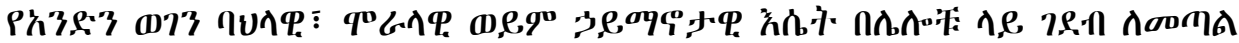

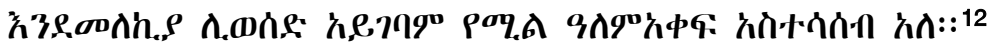

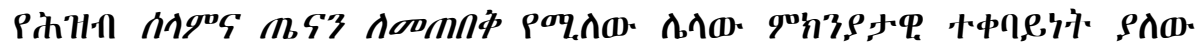

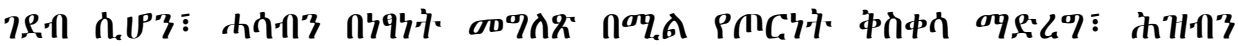

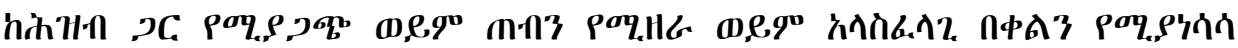

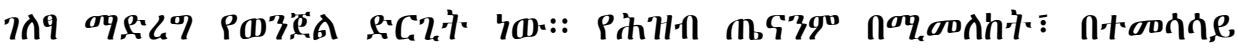

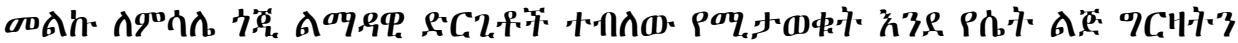

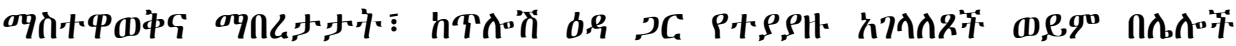

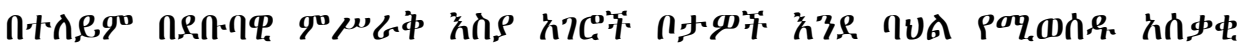

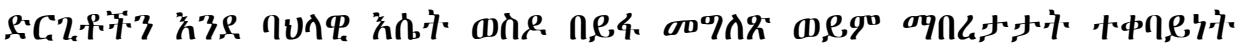

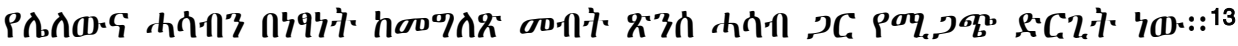

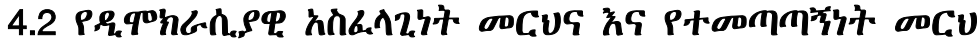

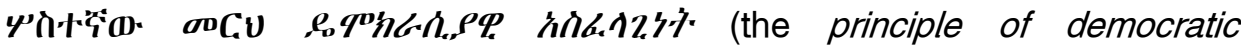

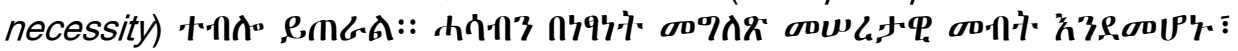

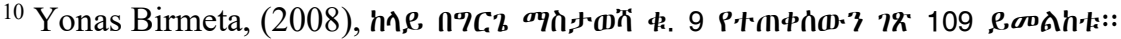

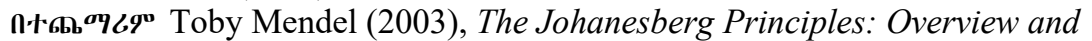
implementation, $\mathbf{7 \%} 8$, eonht::

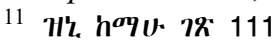

12 United Nations Human rights Committee General Comment \# 30 $0^{\text {th }}$ of July 1993, p. 3.

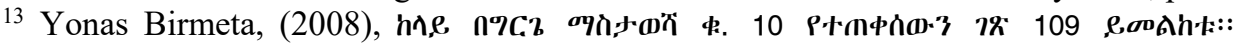
กトณ\% G9 Mendel, Toby, (2003), The Johanesberg Principles: Overview and

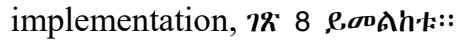




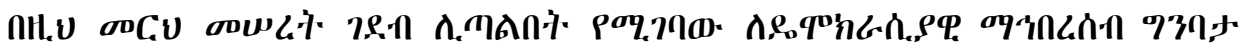

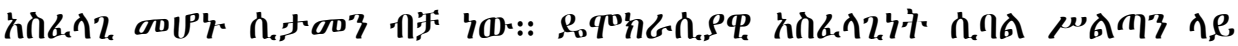

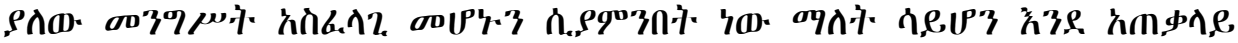

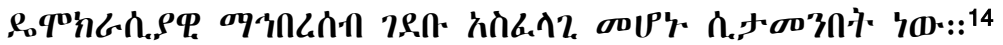

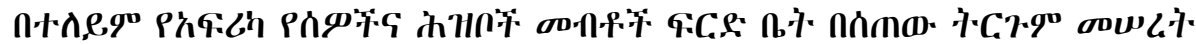

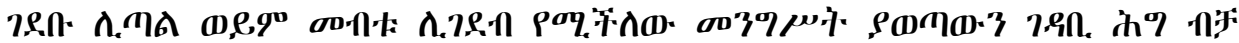

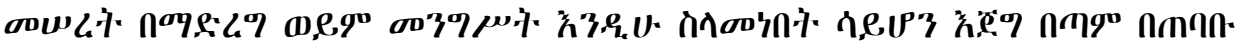

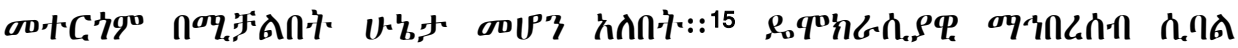

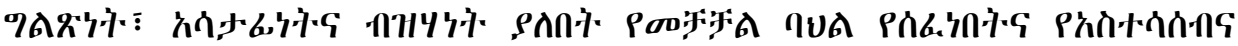

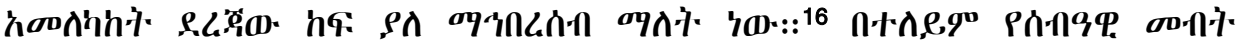

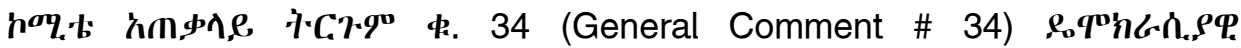

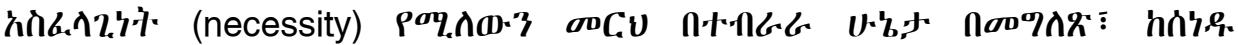

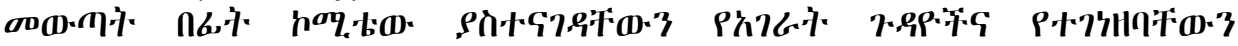

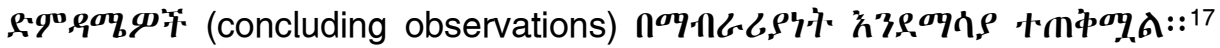

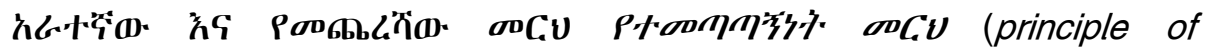

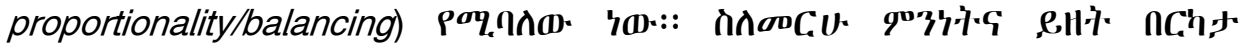

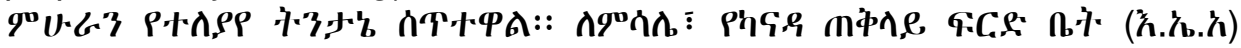

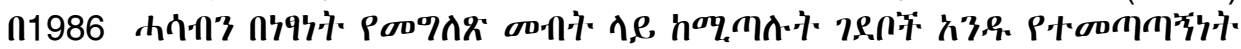

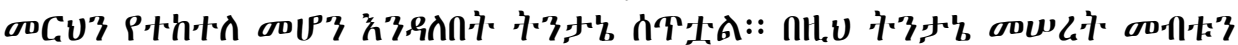

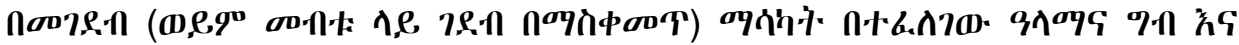

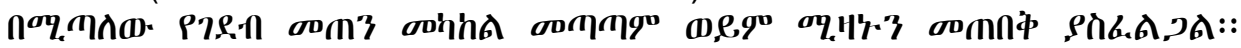

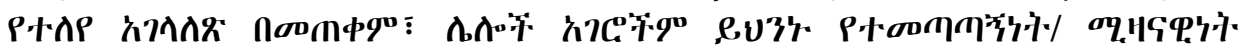

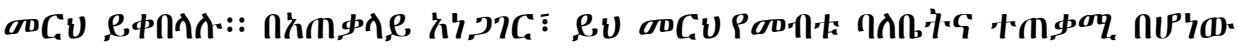

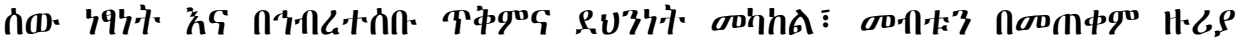

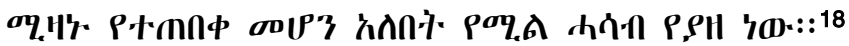

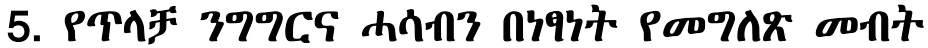

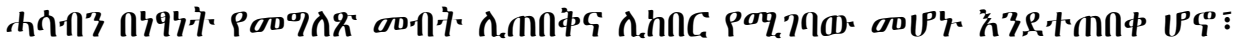

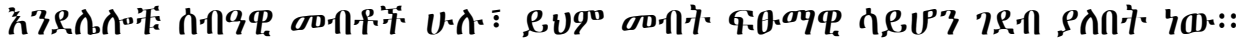

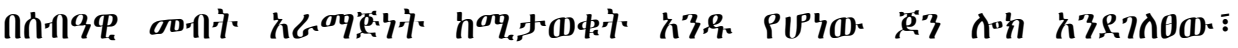

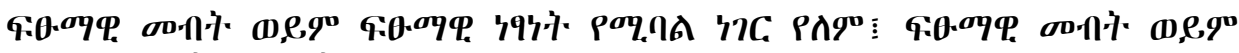

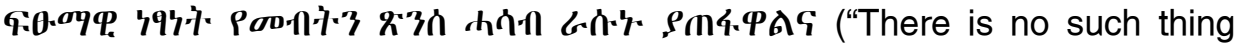

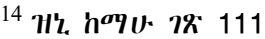

${ }^{15}$ In the matter of Lohe Issa Konate Vs. Burkina Faso, application number 004/2013, African Court on Human and Peoples Rights, pp. 19-20.

16 H's. hov.

${ }^{17}$ United Nations Human Rights Committee General Comment \# 34 of $29^{\text {th }}$ July 2011 p. 9.

18 Gregoire Webber (2019), 'Proportionality and limitations on Freedom of Speech', Queen's Law Research Paper Series, p. 13.
} 
as absolute freedom as absolute freedom destroys the concept of freedom itself")::19

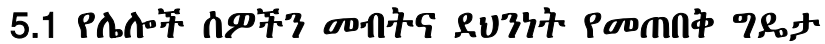

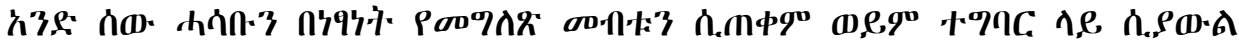

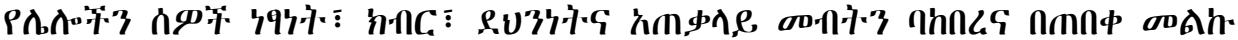

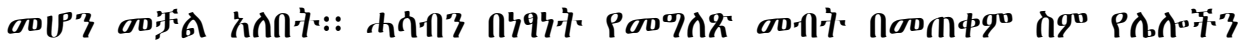

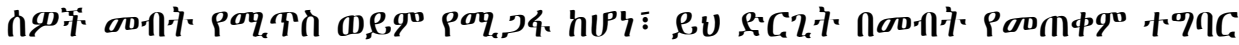
n,

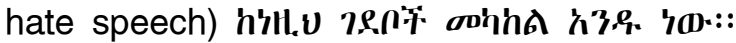

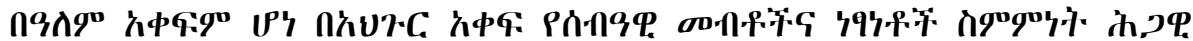

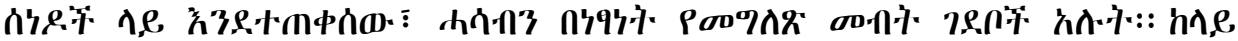

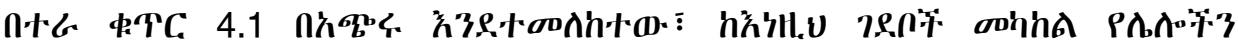

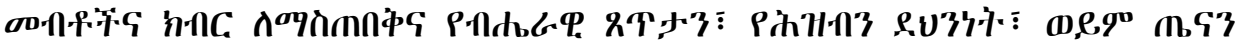

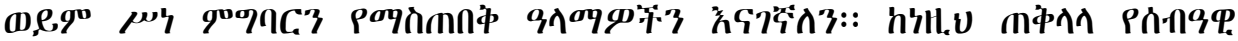

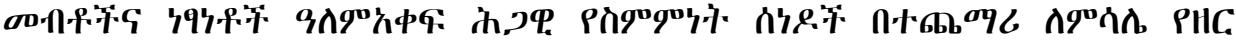

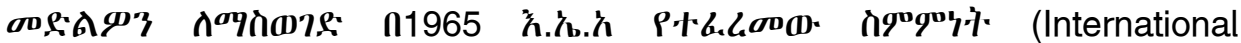
Convention on the Elimination of all Forms of Racial Discrimination

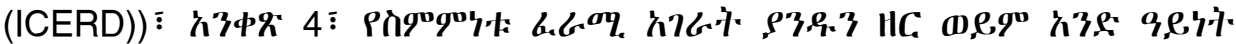

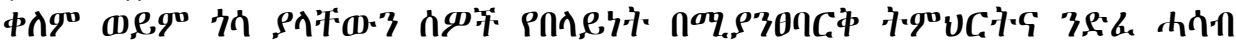

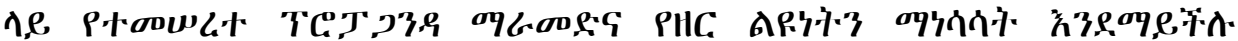

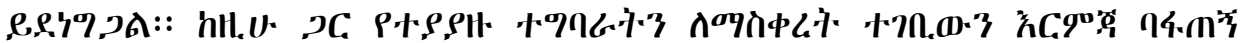
ก\%0(D)

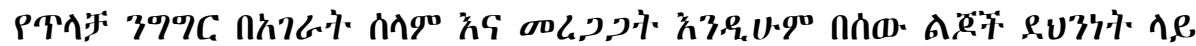

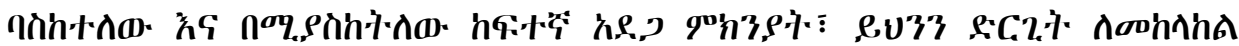

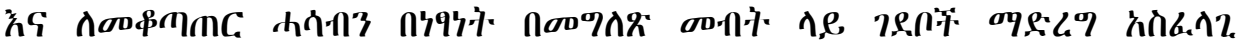

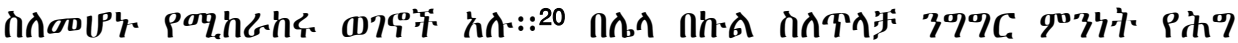

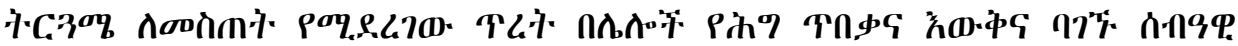

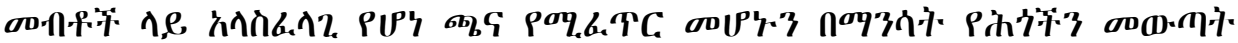

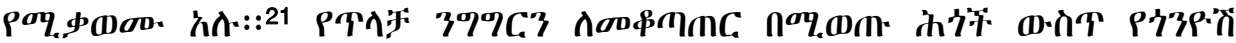

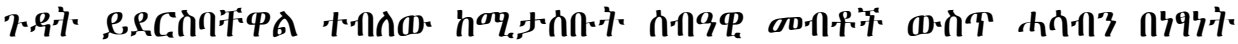

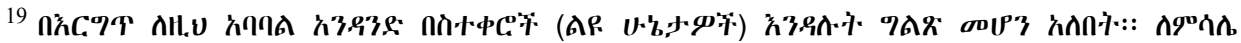

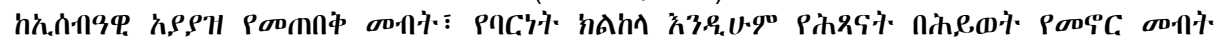

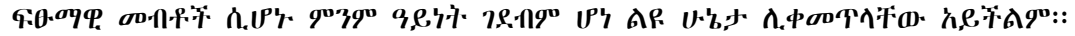

${ }^{20}$ Andrea Schefler (2015) The Inherent Dangers of Hate Speech Legislation: A case study from Rwanda and Kenya on the Failure of a Preventive measures, (fesmedia Africa, Friedrich-Ebert-Stiftung), pp. 9-10;

Available at: https:/library.fes.de/pdf-files/bueros/africa-media/12462.pdf;

Henry Maina, The Prohibition of Incitement to Hatred in Africa: Comparative Review and Proposal for a Threshold, A Study Prepared for the Regional Expert Meeting on Article 20, Organized by the Office of the High Commissioner for Human Rights, Nairobi, (April 6-7, 2011).

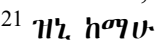


Freedom of Expression and Hate Speech in Ethiopia: Observations (in Amharic) 205

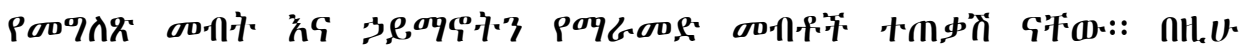

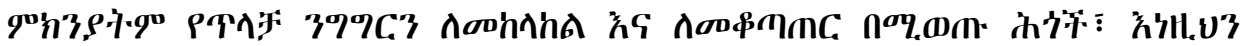

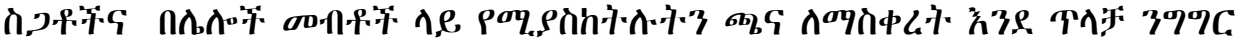

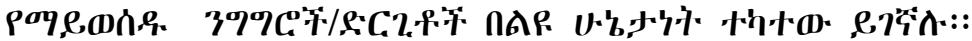

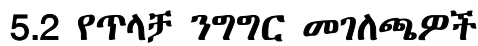

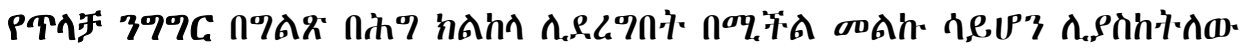

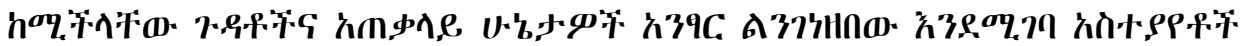

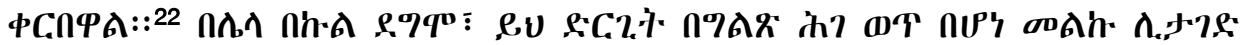
え3.

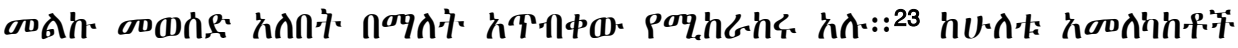

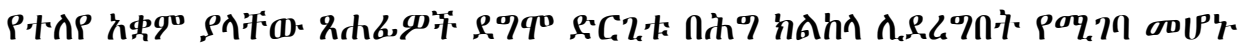
ह3.

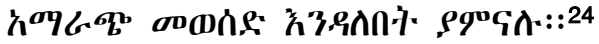

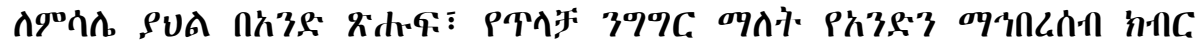

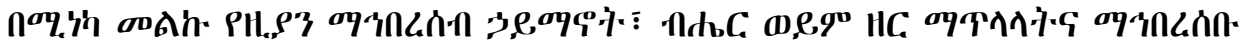

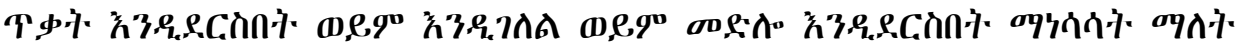

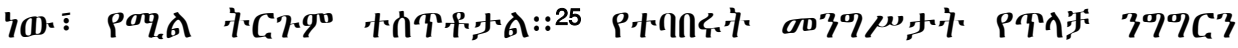

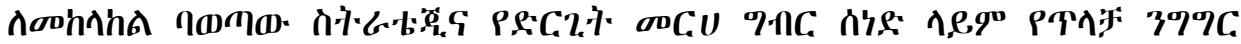

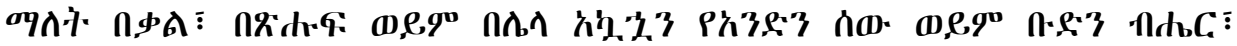

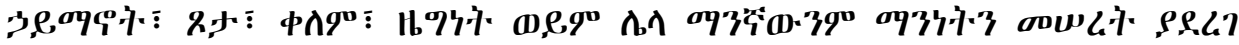

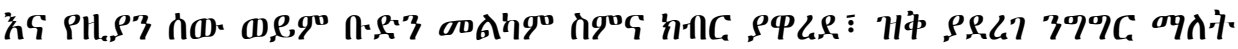

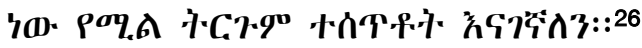

${ }^{22}$ Calvin R. Massey (1992), 'Hate Speech, Cultural Diversity, and the Foundational Paradigms of Free Expression', 40 UCLA L. Rev. 103 1\% 155

${ }^{23}$ Mari J. Matsuda (1989), 'Public Response to Racsist Speech: Considering the Victims Story', Michigan Law Review, $7 \% 2380$

${ }^{24}$ Bhikhu Parekh, 'Is There a Case for Banning Hate Speech?' Cited in Sellars, F. Andrew, (2016), Defining Hate Speech, Research Publication No. 2016-20, The Berkman Klein Center for Internet \& Society Research Publication Series: The Social Science Research Network Electronic Paper Collection, Boston University School of Law, Public Law Research paper $7 \% 1415$

25 " ... hate speech constitutes denigration of the reputation of a social group, stereotyped by some particular national, racial or religious characteristics, accompanied by incitement to hostility, violence and discrimination against that group"

Fabio Maneli, Repression of hate speech: its foundation in international and European law in Hate Crime and Hate speech in Europe: Comprehensive analysis of International law principles, Eu-wide study and national assessements, PRISM Research Project, $7 \% 11$

${ }^{26}$ United Nations Strategy and Plan of Action on Hate Speech, A Synopsis, May, 2019, p. 2 


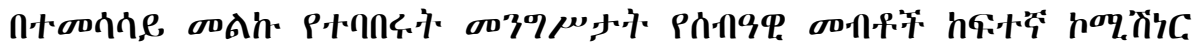

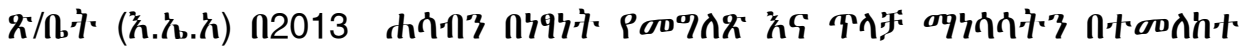

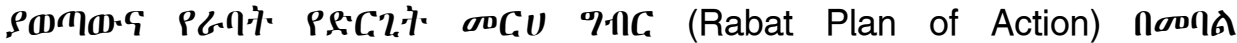

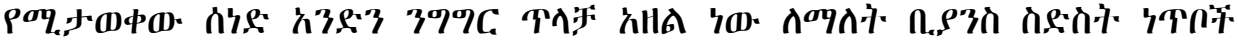

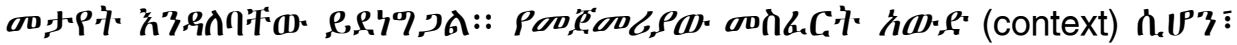

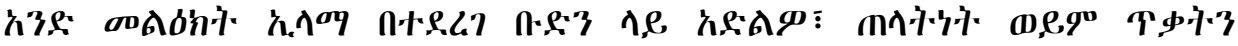

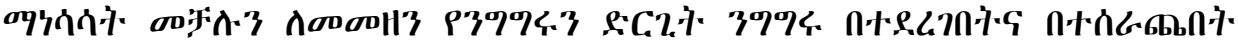

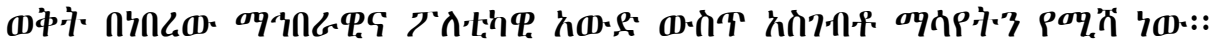

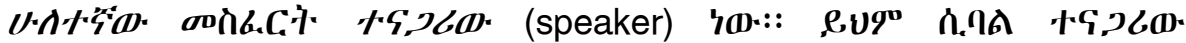

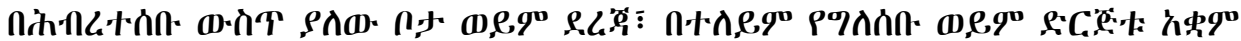

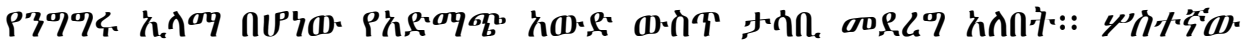

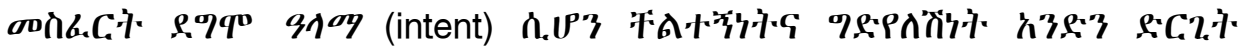

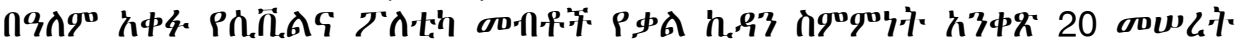

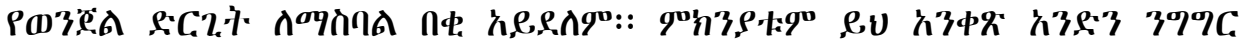

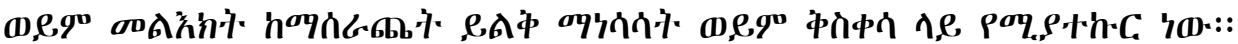

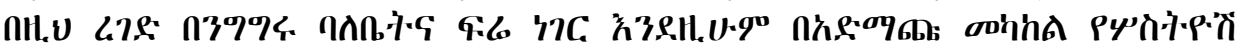

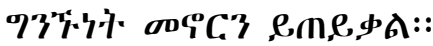

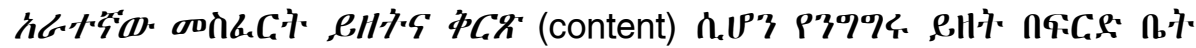

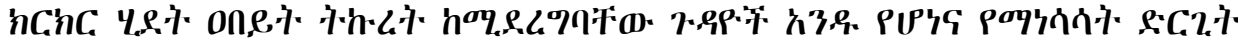

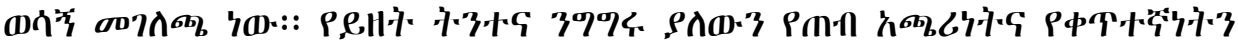

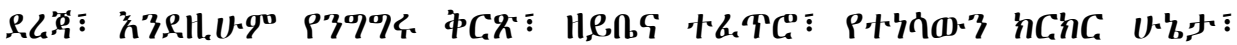

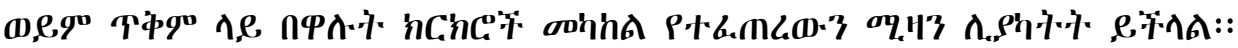

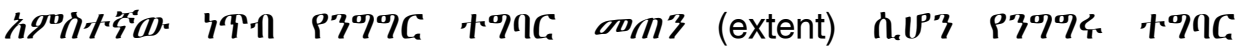

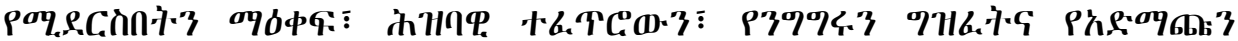

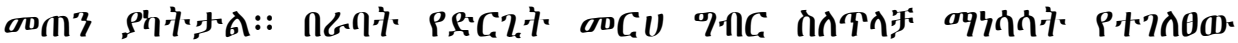

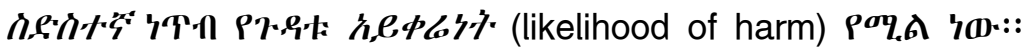

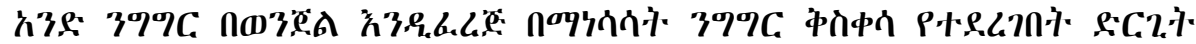

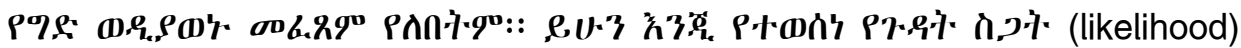

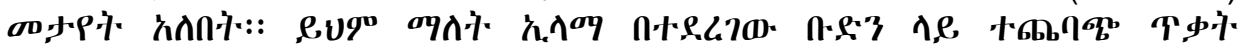

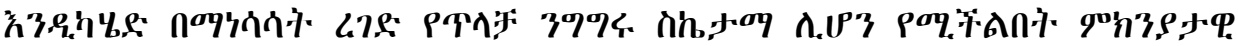

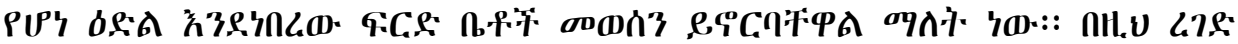

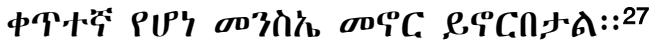

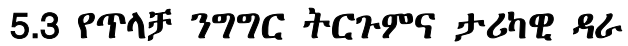

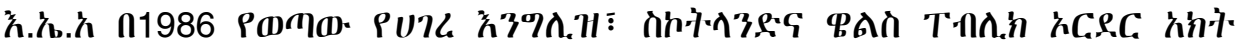

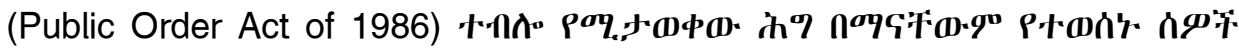

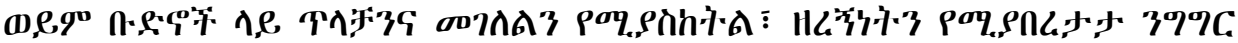

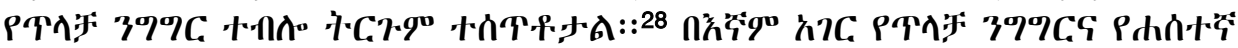

\footnotetext{
${ }^{27}$ The UN High Commisioner for Human Rights, The Rabat Plan of Action on the Freedom of Expression Vs. Incitement to hatred, 2013.

${ }^{28}$ Sec. 18 of the Public Order Act of England, Scotland and Wales.
} 


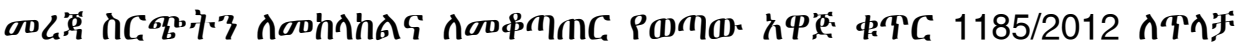

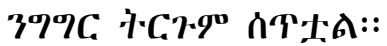

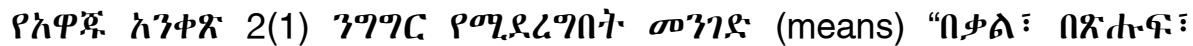

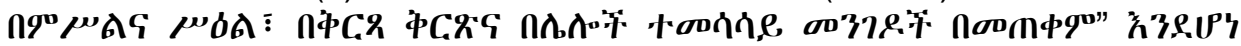
לרA : :

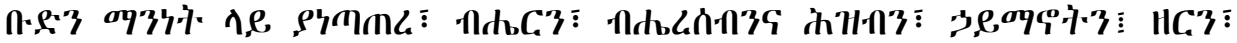

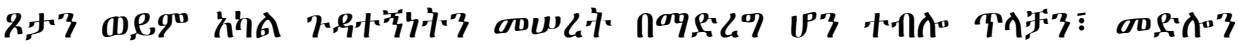

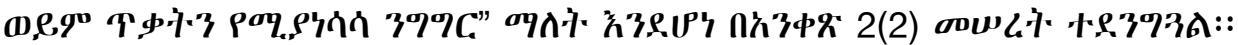

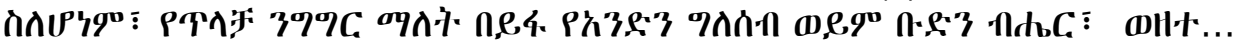

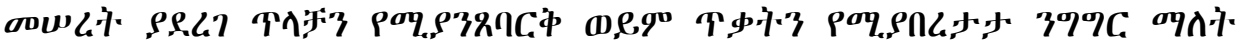

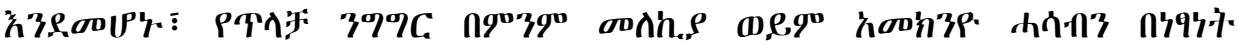

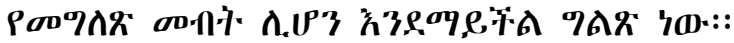

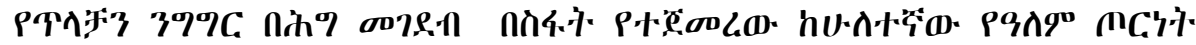

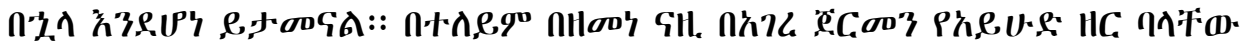

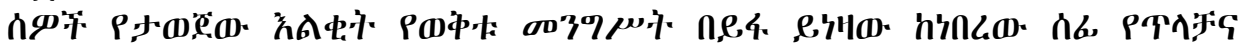

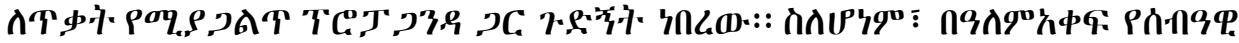

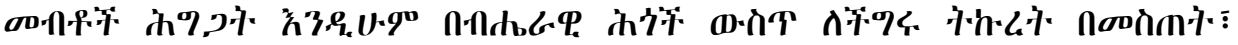

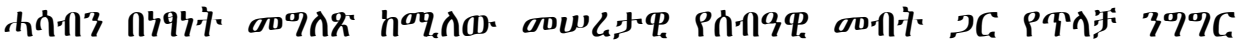

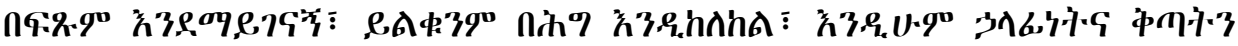

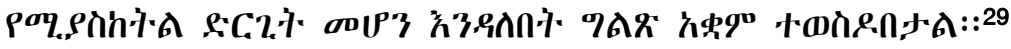

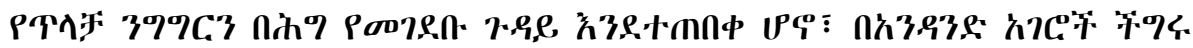

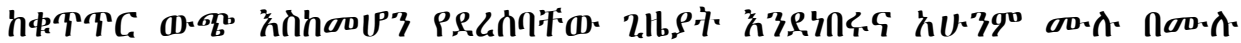

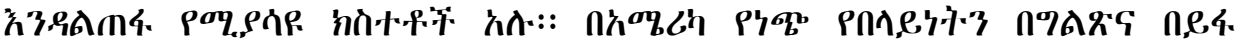

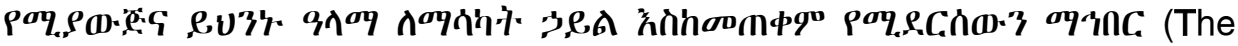

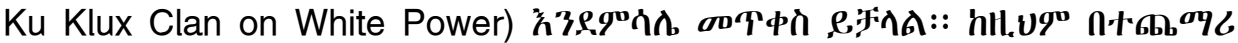

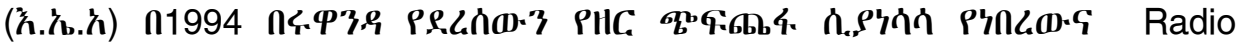

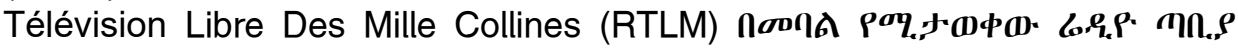

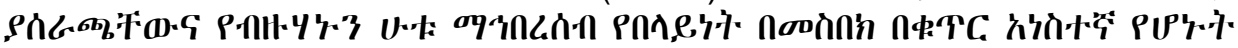

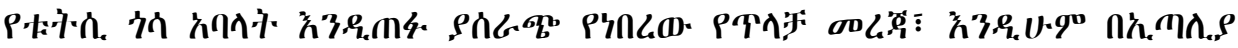

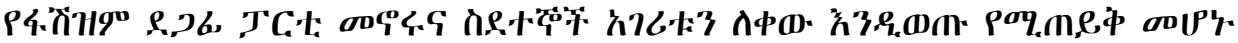

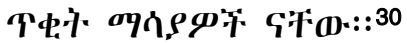

29 Stephanie Farrior (1996), 'Modeling the Matrix: The Historical and Theoretical Foundations of International Law concerning Hate Speech', Berkley Journal of International Law Vol. 14 \# 1 7\% 25. กஈณ\% 中. 7 7\% 1525 , emant:

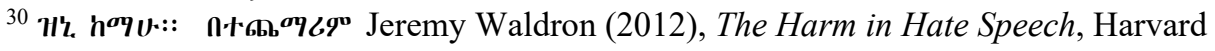
University Press, $7 \%$, 34 onAht:: 


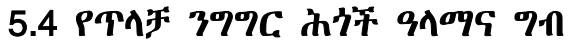

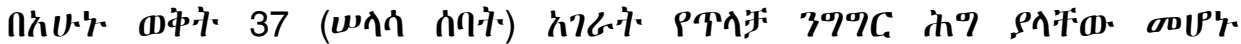

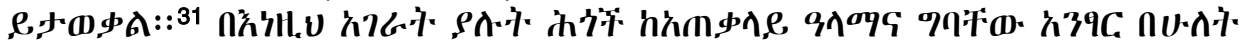

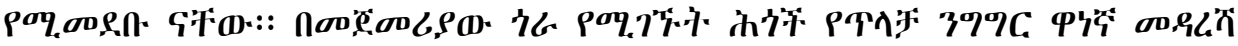

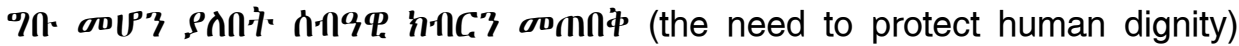

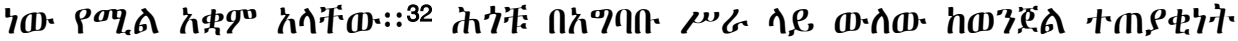

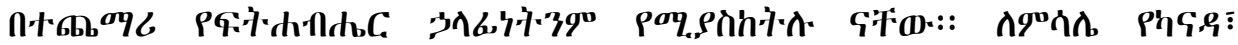

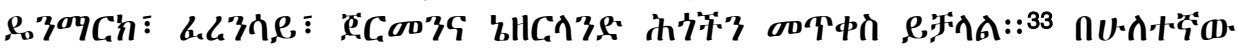

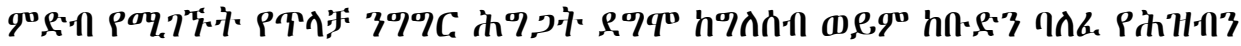

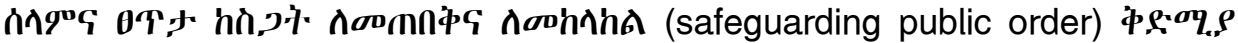

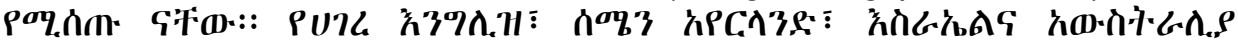

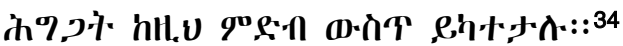

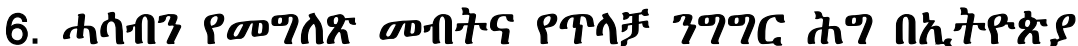

\section{1 \$20039}

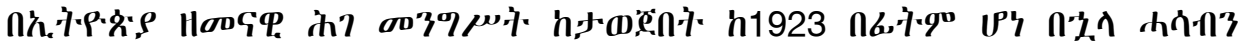

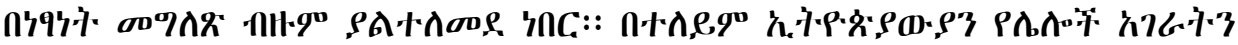

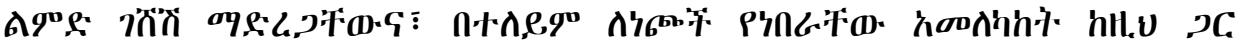

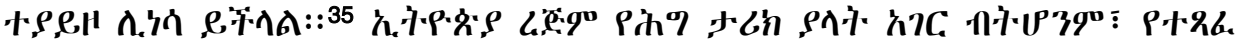

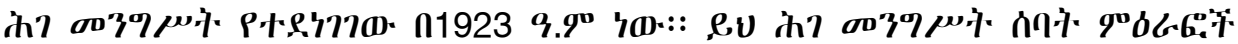

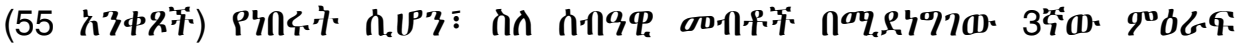

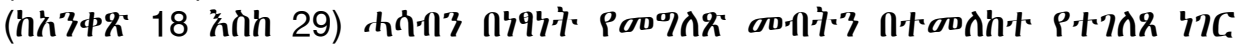

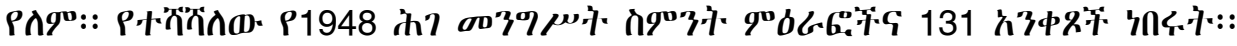

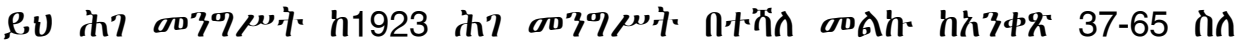

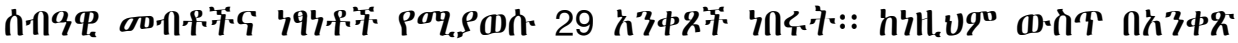

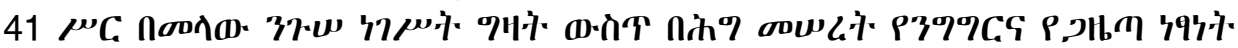

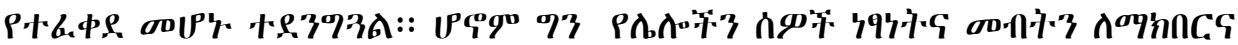

${ }^{31}$ Radio Interview hosted by Mellisa Block on Comparing Hate Speech laws in the US and Abroad with Charles Asher Small-Founder of the Yale Initiative for the interdisciplinary study of Anti-Semtism (March 3, 2011), accessed on 14 ${ }^{\text {th }}$ August 2021). e Study on Hate speech and Armenian Legislations (A Research document funded by European Union and Council of Europe of the Project Strengthening access to justice through non-judicial redress mechanisms for victims of discrimination, hate crime and hate speech in Eastern partnership countries)

32 Jeannine Bell (2009), 'Restraining the Heartless: Racsist Speech and Minority Rights', Indiana Law Journal, Vol. 84 issue 3, p. 968

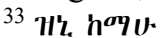

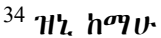

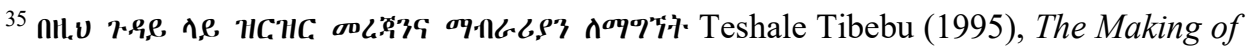
Modern Ethiopia (1896-1974), The Red Sea Press INC., Lawerenceville NJ, USA, pp. $5-7$ 


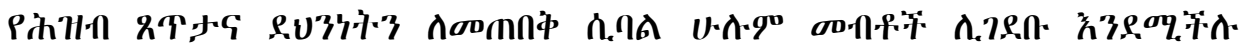

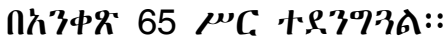

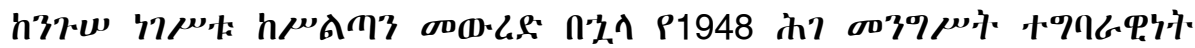

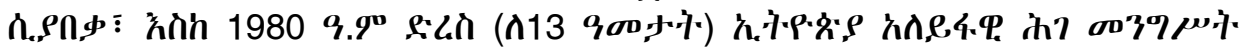

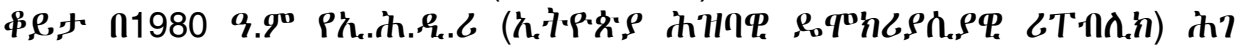

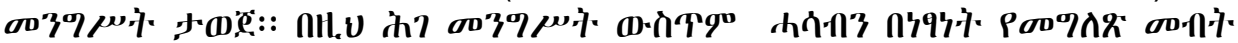

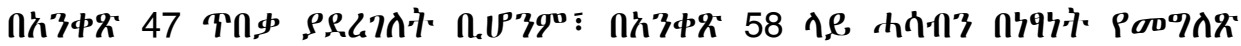

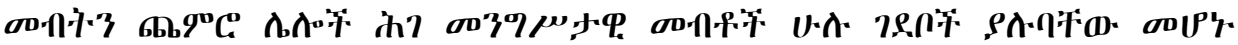

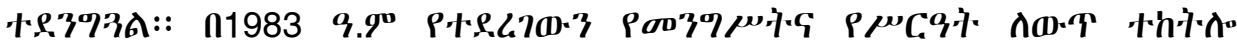

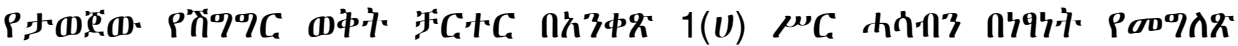

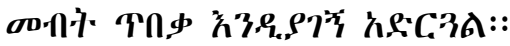

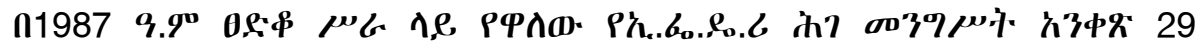

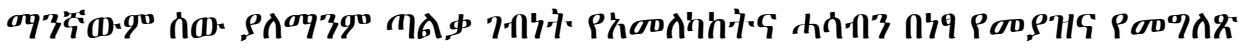

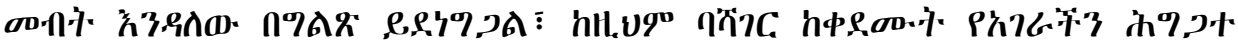

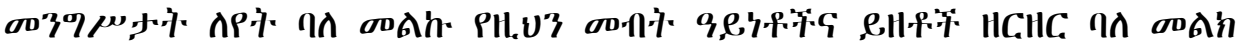

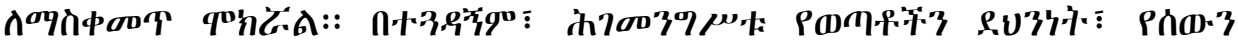

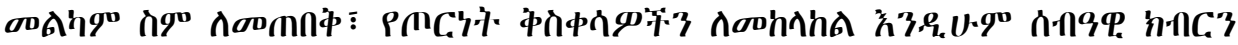

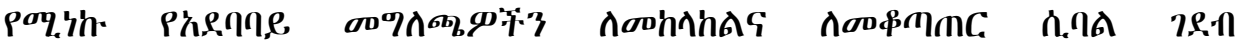

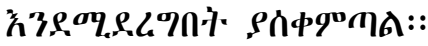

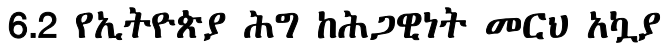

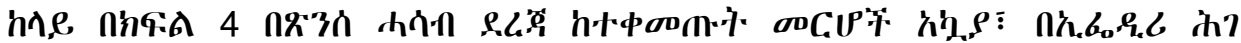

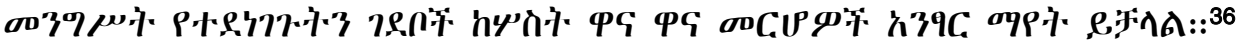

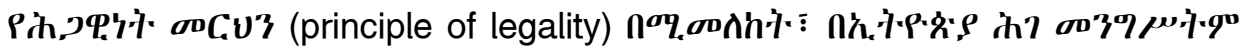

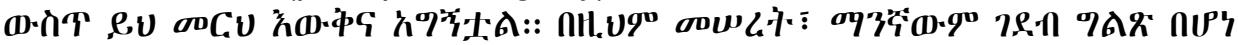

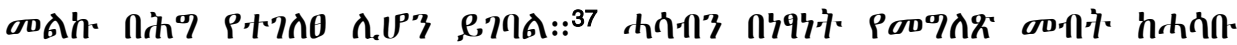

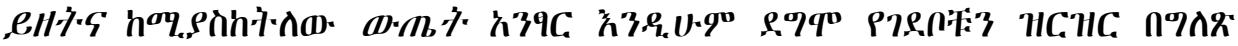

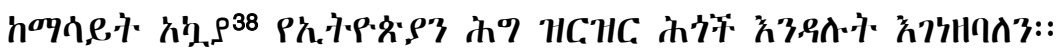

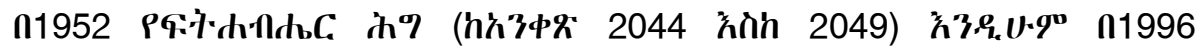

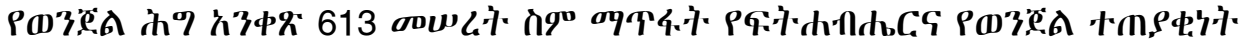

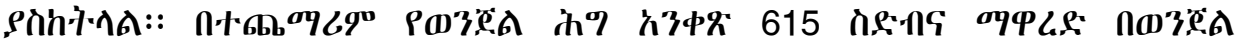

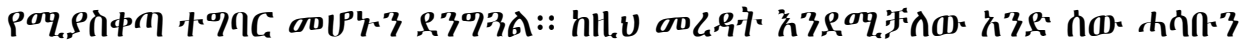

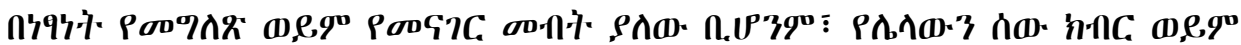

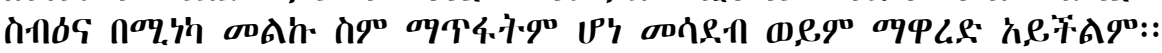

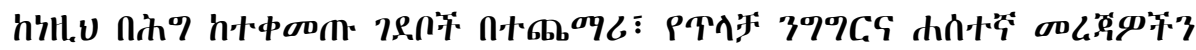

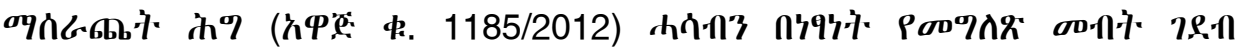

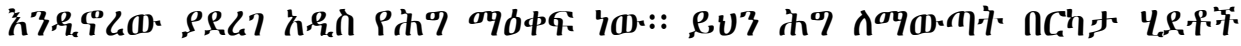

\footnotetext{
${ }^{36}$ Girmachew A., Yonas B., and Wondmagegn T. (2013), Ethiopian Human Rights HandBook, ABA/USAID Publication, Addis Ababa, Ethiopia, p. 104.

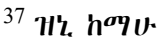

${ }^{38}$ H't $^{3}$ h $^{\text {oq }}$.
} 


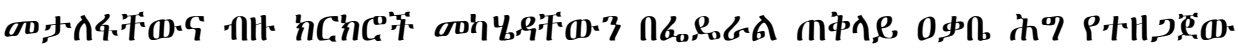

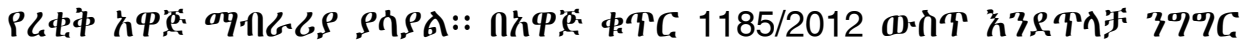

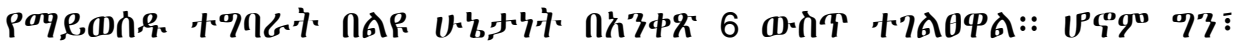

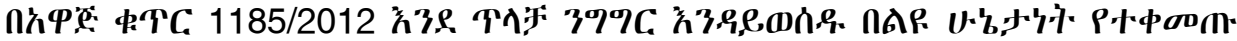

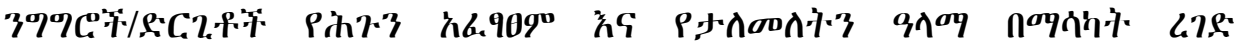

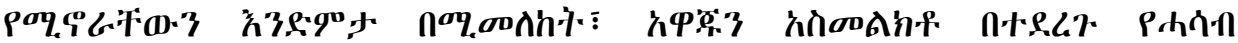

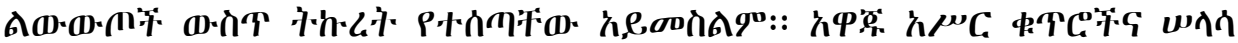

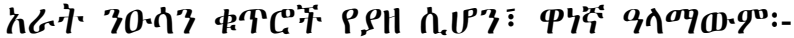

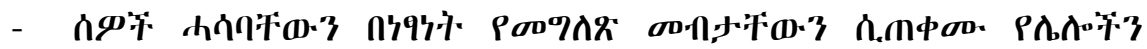

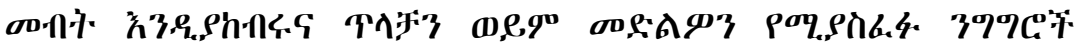

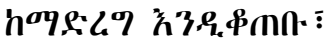

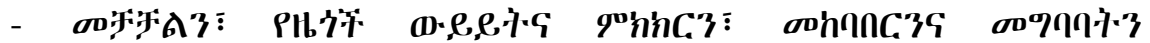

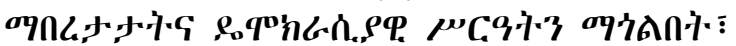

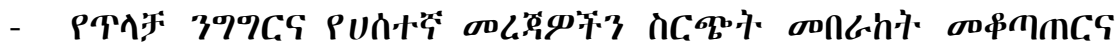
व0\%ग\%

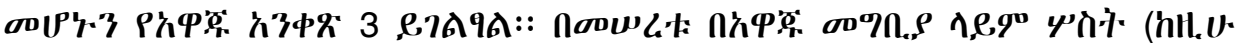

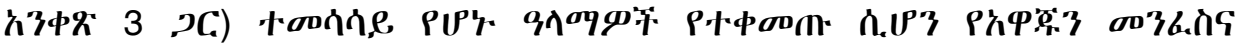

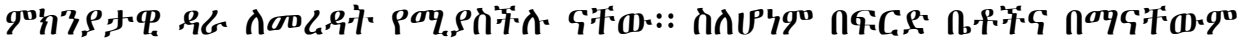

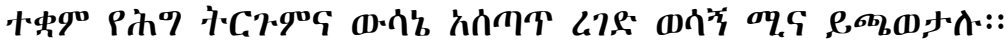

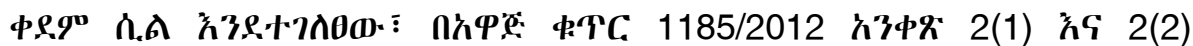

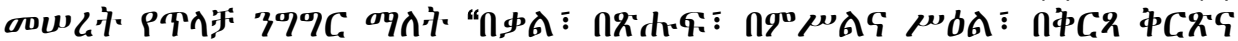

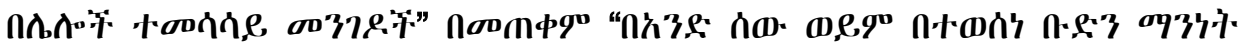

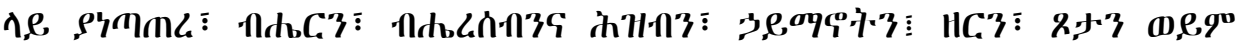

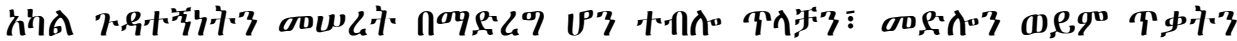

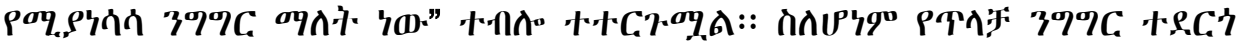

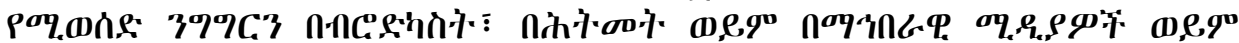

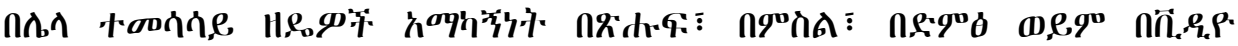

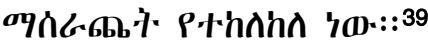

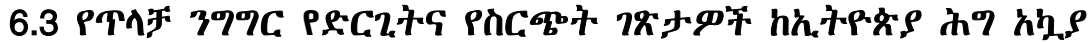

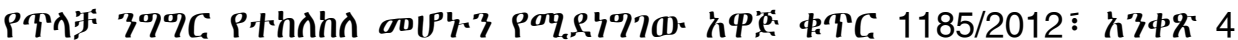

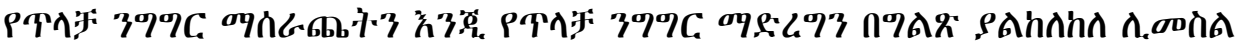

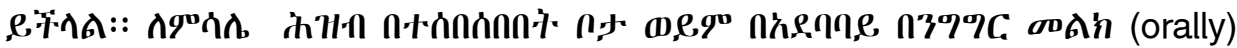

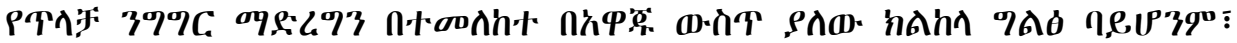

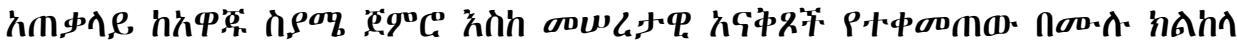

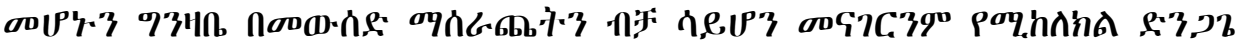

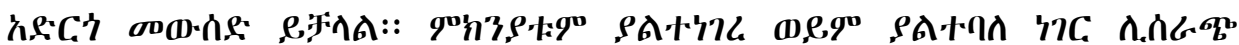

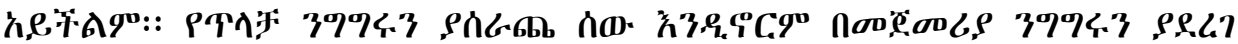

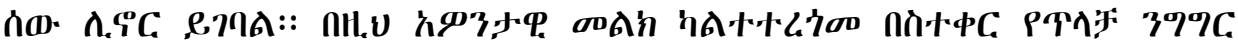

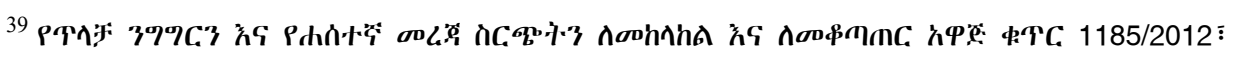
h'\$中\% 4 
Freedom of Expression and Hate Speech in Ethiopia: Observations (in Amharic) 211

h. P.

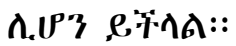

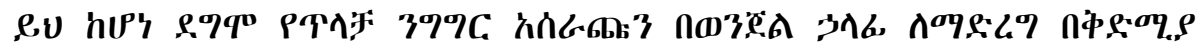

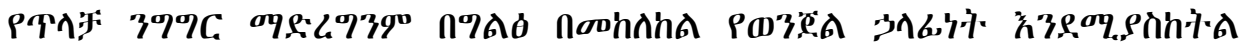

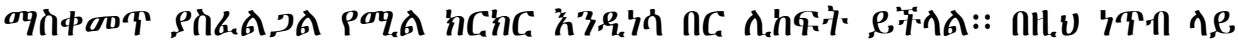

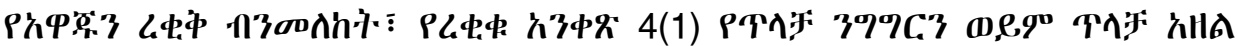

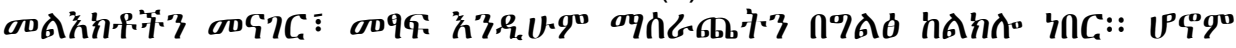

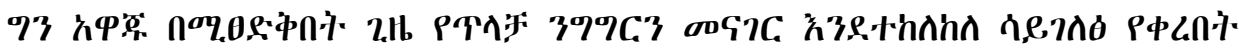

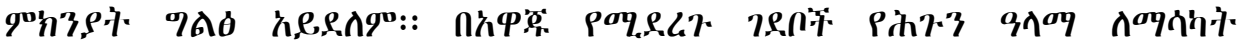

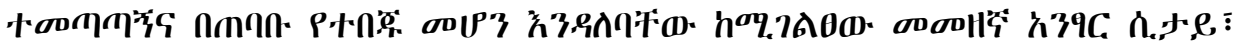

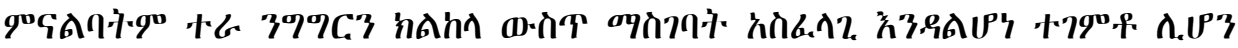

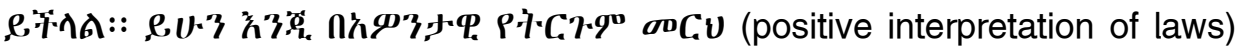

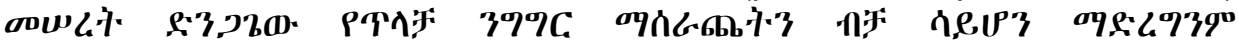

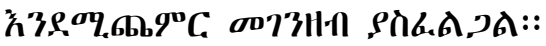

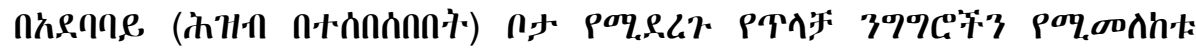

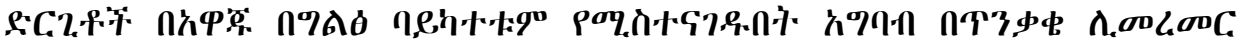

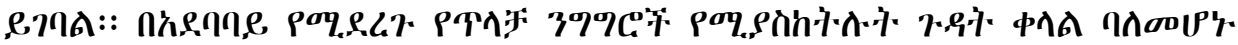

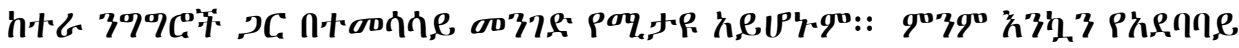

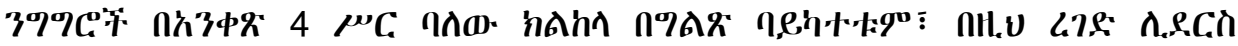

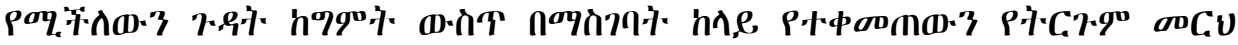

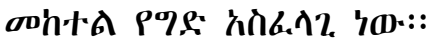

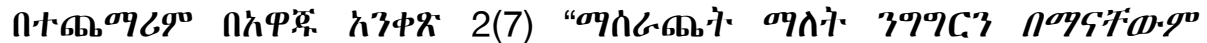

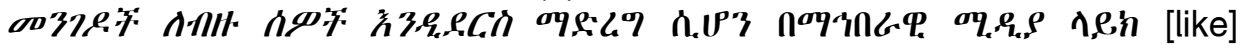

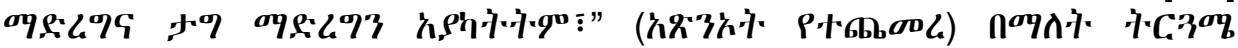

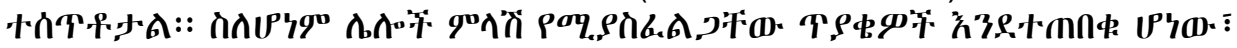

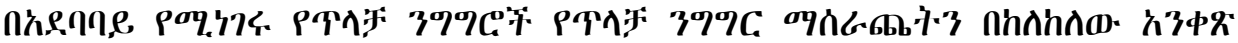

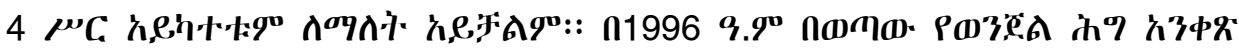

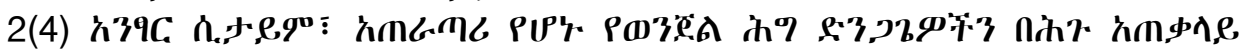

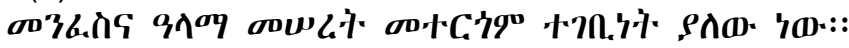

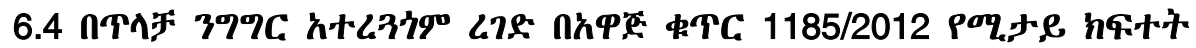

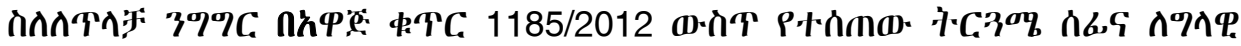

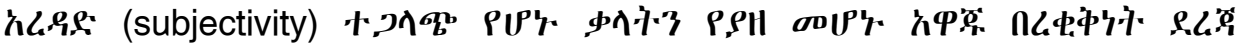

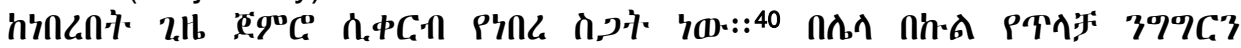

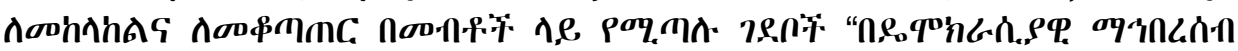

${ }^{40}$ Girmachew Alemu, Narrow Hate Speech Law Will Not Broaden Minds, (January 24, 2020), available at https://www.ethiopia-insight.com/2020/01/24/narrow-hate-speechlaw-will-not-broaden-minds/ : Yohannes Eneyew Ayalew, Muting Sectarianism or Muzzling Speech?, (2020), available at: https://www.ethiopiainsight.com/2020/01/31/muting-sectarianism-or-muzzling-speech/ 氵 Paj; $\mathbf{7 9 \% C G ~}$

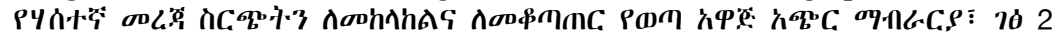




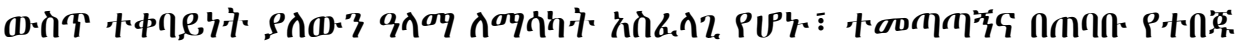

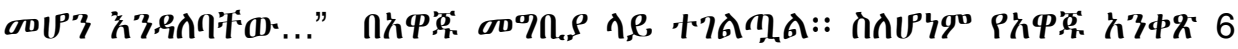

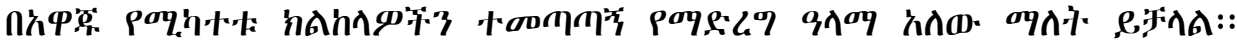

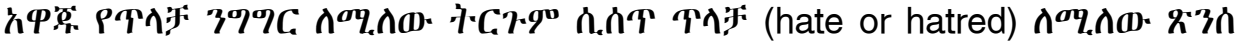

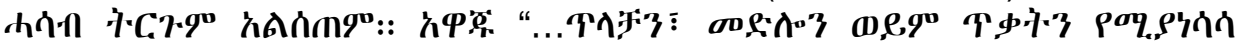

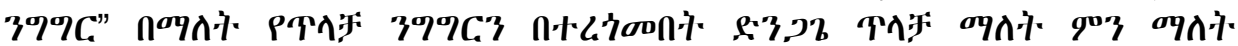

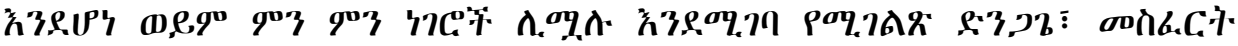

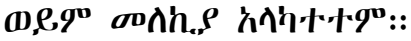

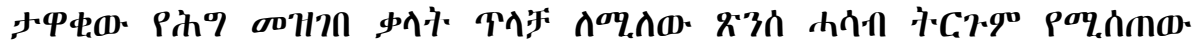

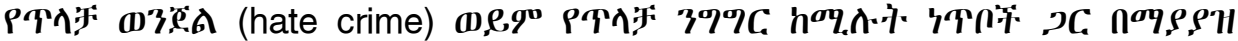

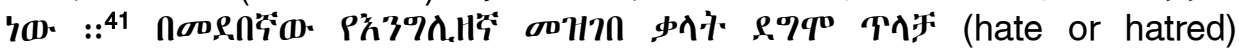

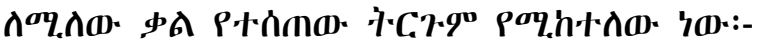

"Hate means to dislike somebody or something intensly or to find something unpleasant or the emotion of intense dislike". ${ }^{42}$ (TतF

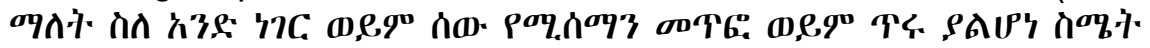

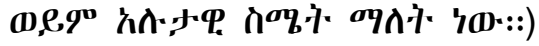

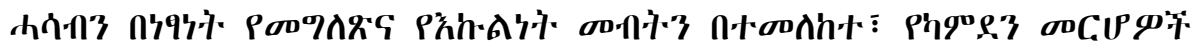
(The Camden Principles on Freedom of Expression and Equality) $\overline{\boldsymbol{m}} \boldsymbol{\alpha} \mathrm{C} v$

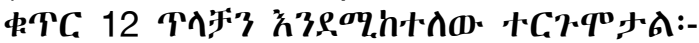

“The terms 'hatred' and 'hostility' refer to intense and irrational emotions of opprobrium, enmity and detestation towards the target

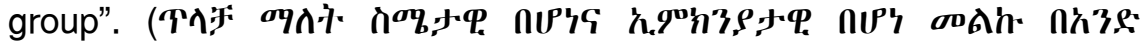

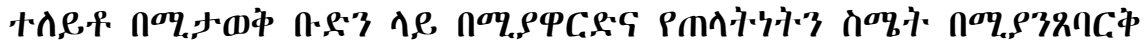

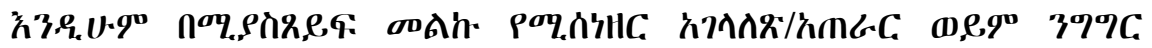
o9n'क $100::)^{43}$

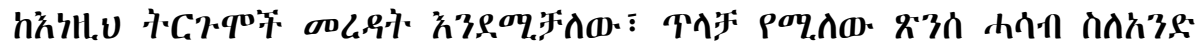

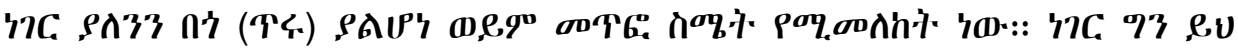

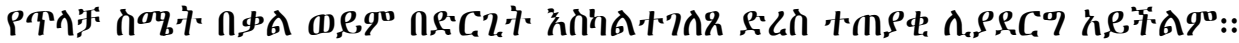

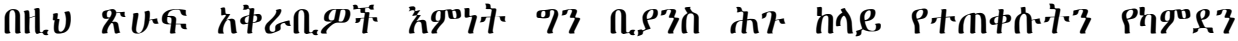

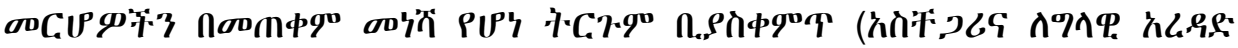

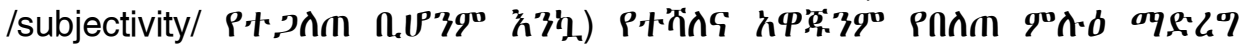

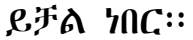

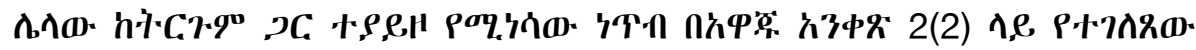

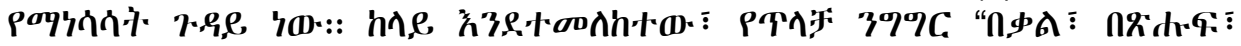

${ }^{41}$ B.A. Garner (Ed.), 2004, Black's Law Dictionary, $8^{\text {th }}$ ed., pp. 1122 and 4381

${ }^{42}$ J. Crowther (Ed.), 1995, Oxford Advanced Learner's Dictionary of Current English, $5^{\text {th }}$ Ed., Oxford University Press, p. 546.

${ }^{43}$ The Camden Principles on Freedom of Expression and Equality, Principle no. 12 (April 2009), Article XIX Global Campaign For Free Expression, p. 10. กヤณ\%69' Yohannes E. Ayalew, (2020), 'Defining Hate Speech under the Hate Speech Suppression Proclamation in Ethiopia, A Sisyphean Exercise?', Ethiopian Human Rights Law Series, Vol. 12, p. 3 , emank:: 
П90

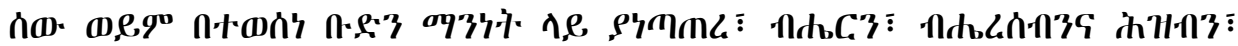

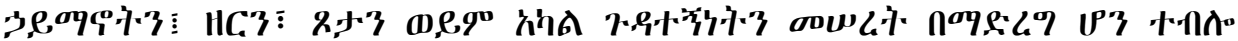

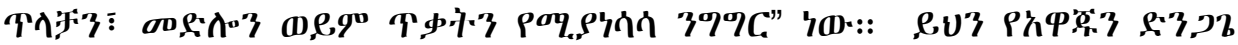

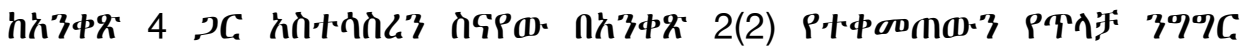

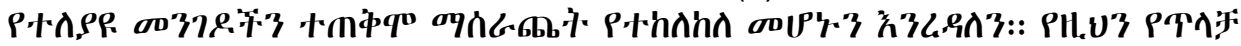

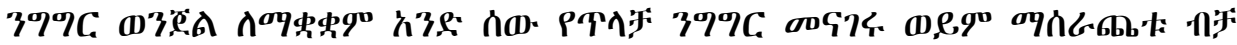

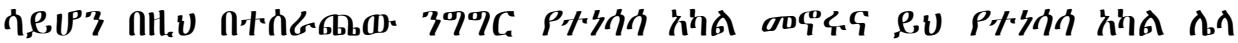

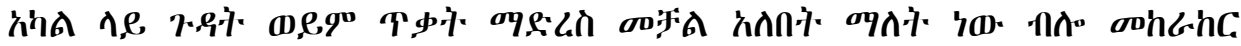
eFกล::

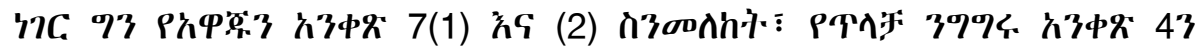

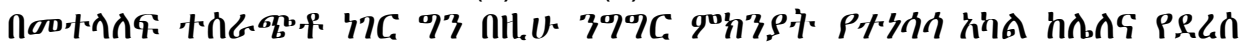

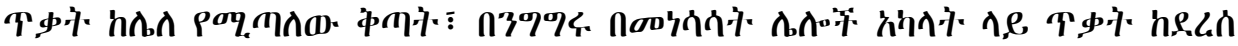

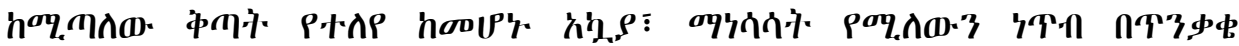

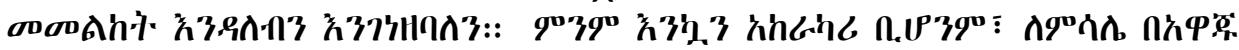

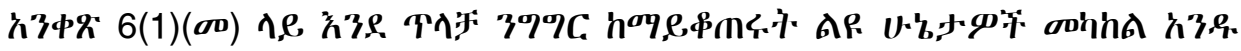

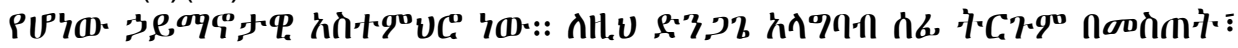

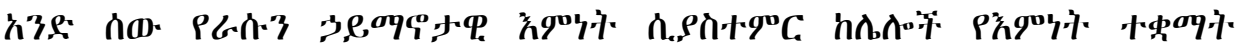

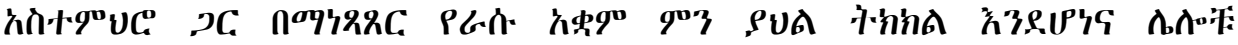

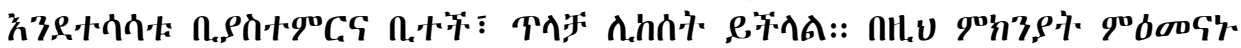

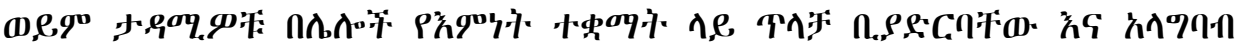

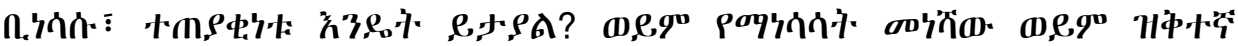

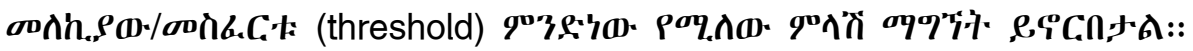

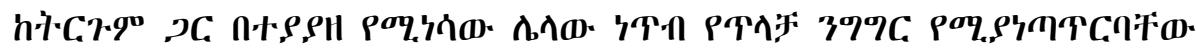

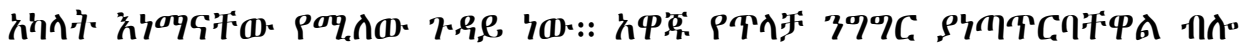

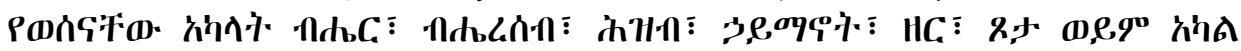

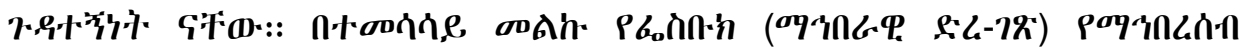

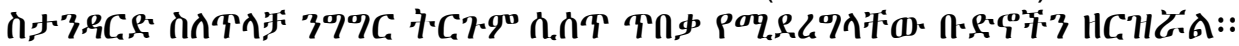

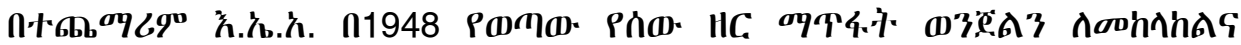

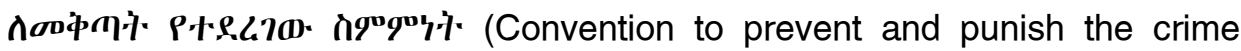

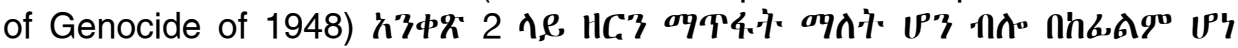

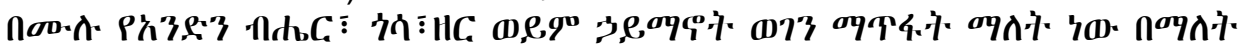
+C.7. ,

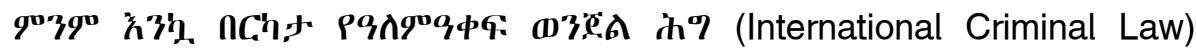

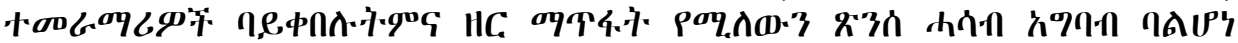

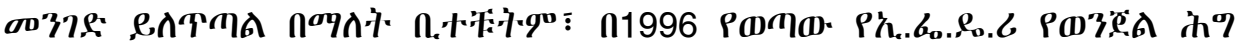

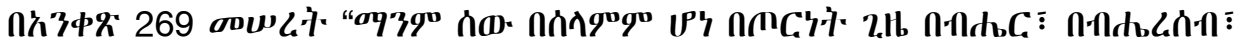

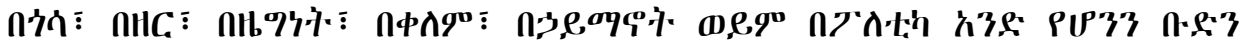

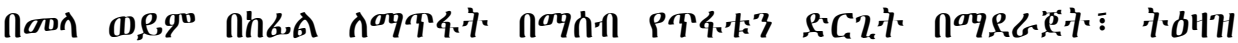

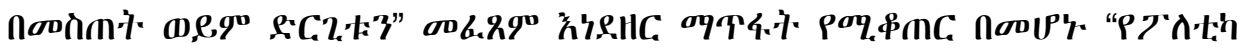

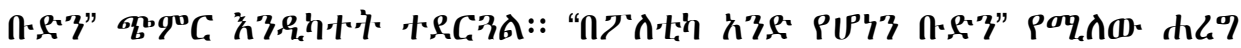

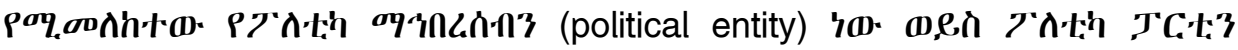

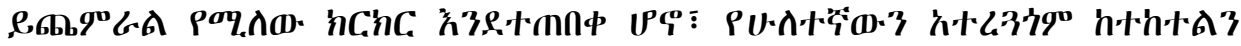




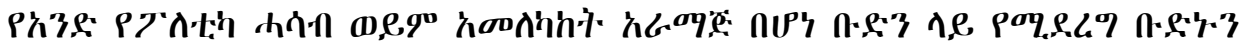

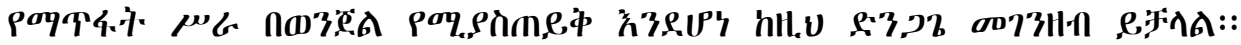

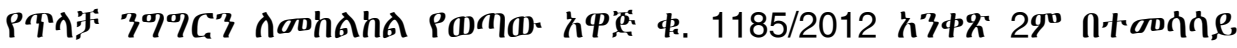

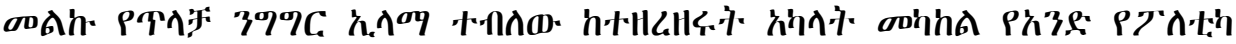

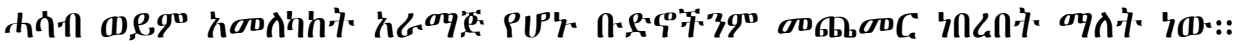

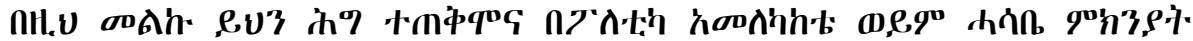

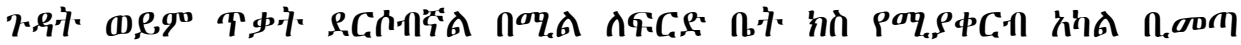

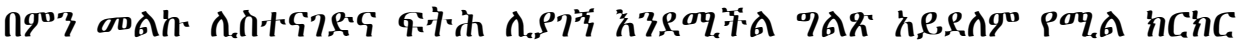

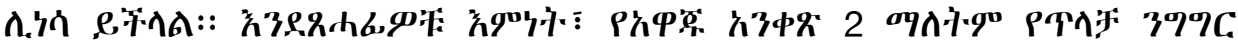

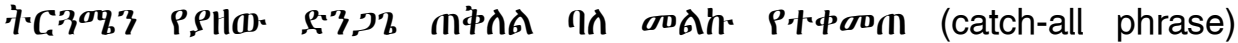

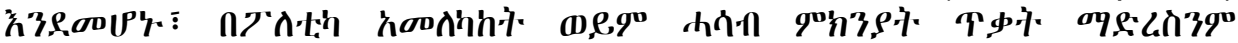

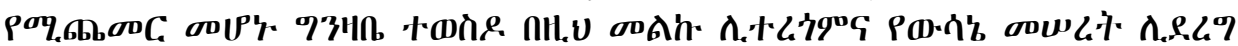

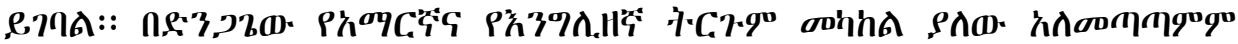

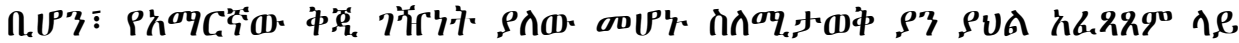

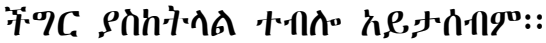

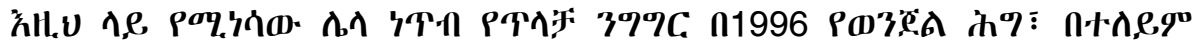

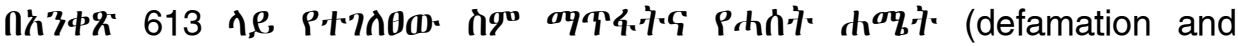

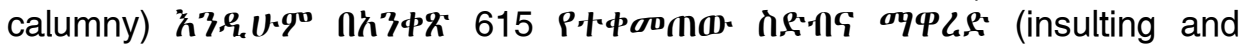
outrage behavior) W3.

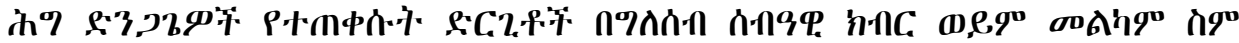

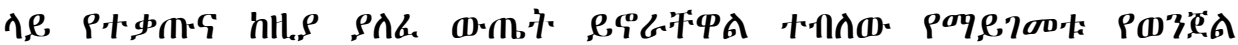

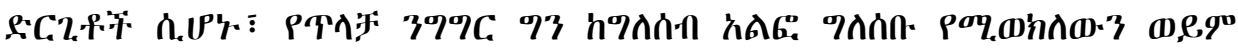

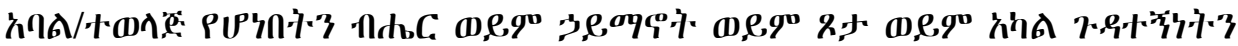

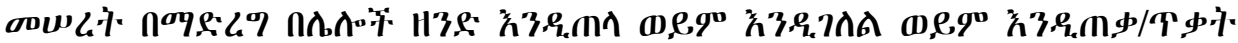

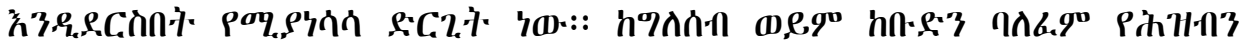

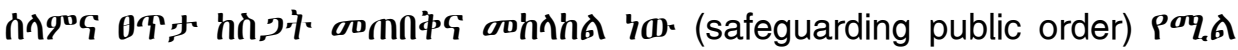

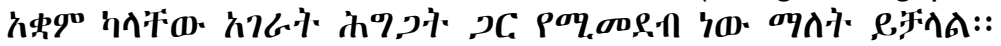

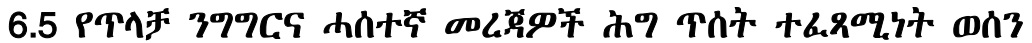

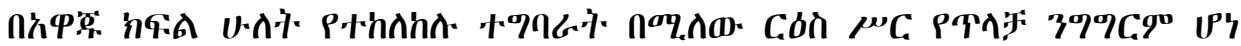

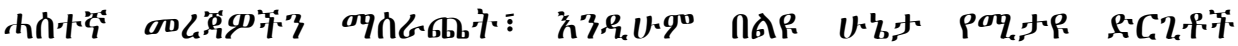

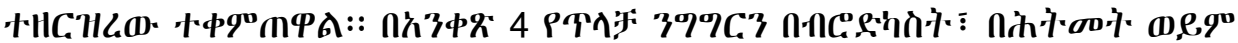

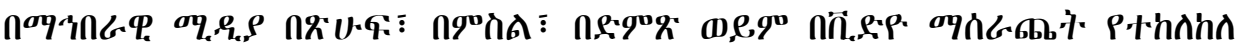

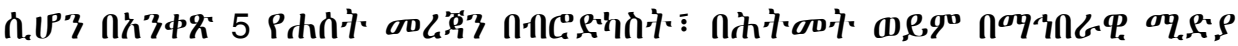

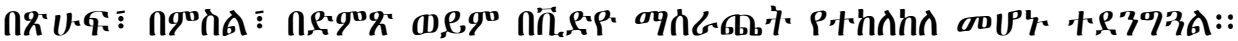

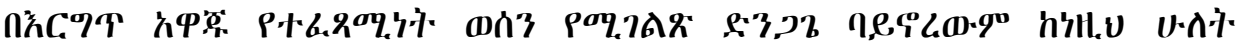

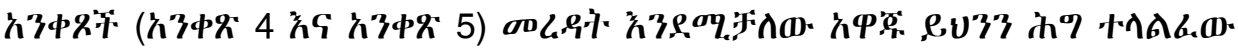

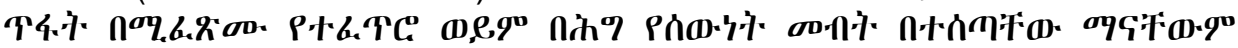

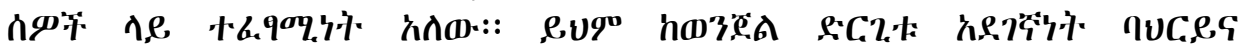

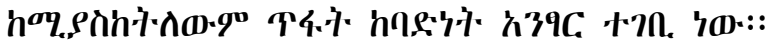

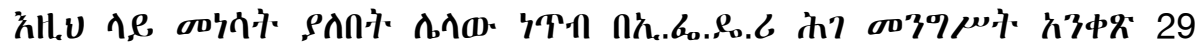

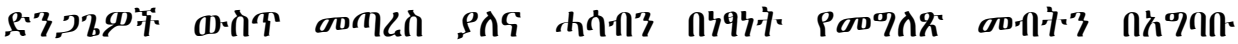

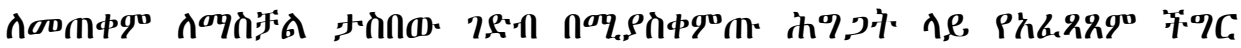

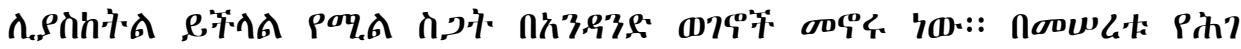




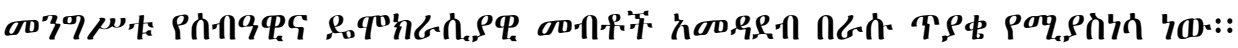

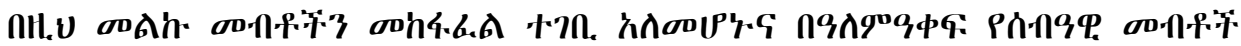

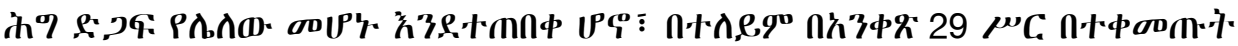

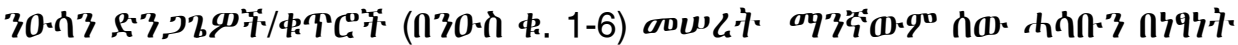

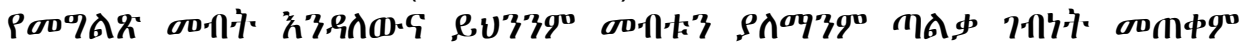

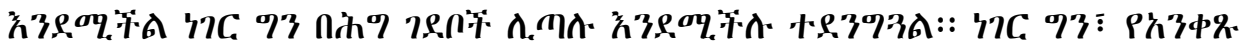

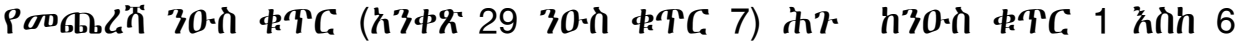

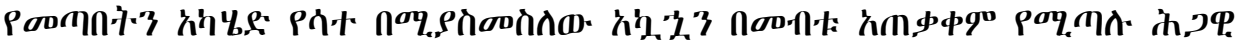

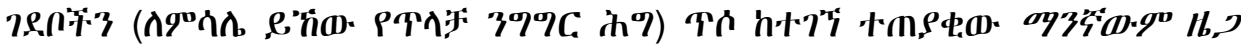

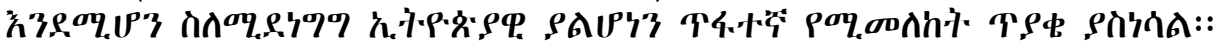

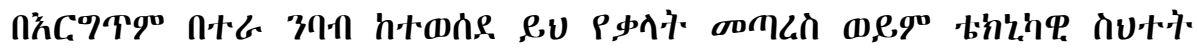
(drafting error) n. $00 \mathrm{\lambda}$,

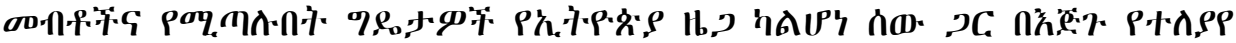

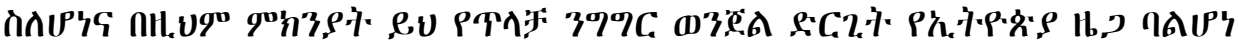

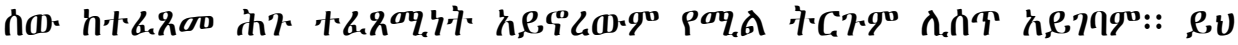

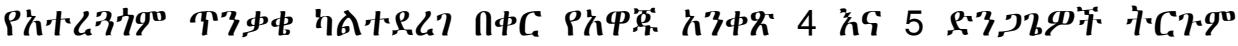

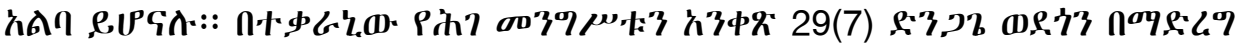

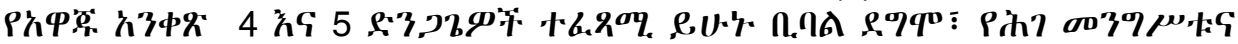

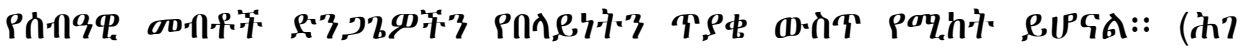

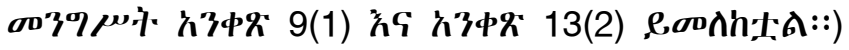

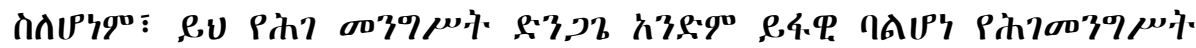

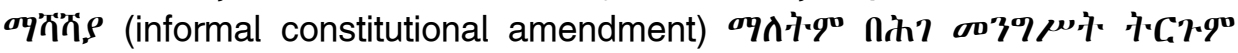

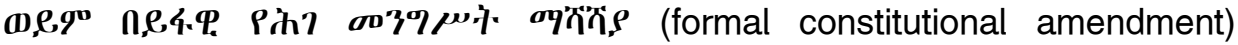

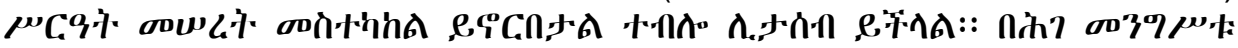

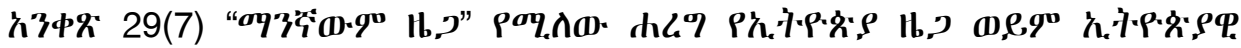

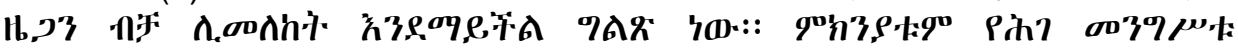

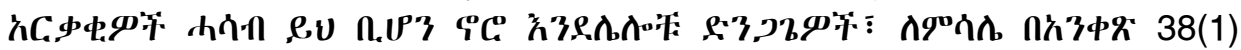

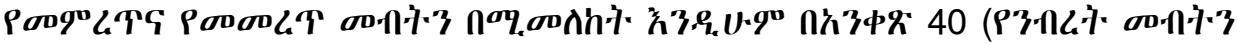

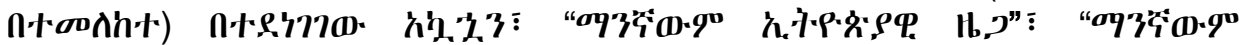

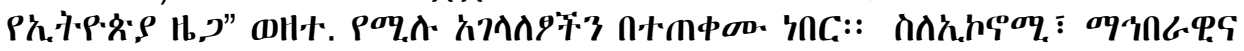

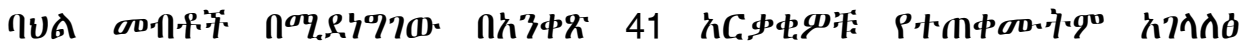

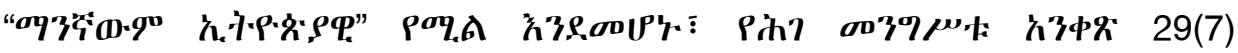

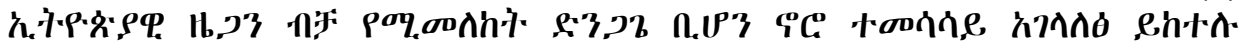
inc::

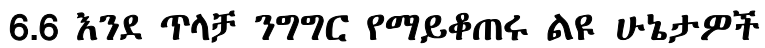

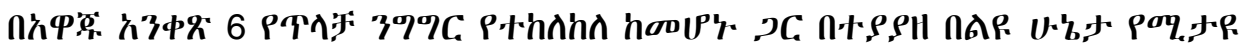

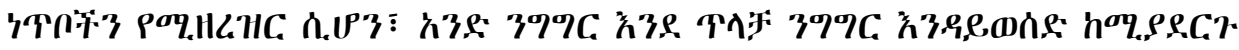

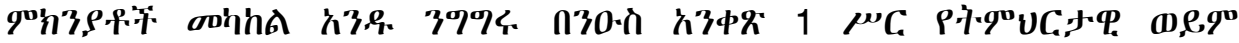

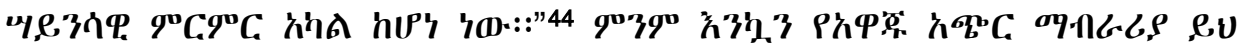

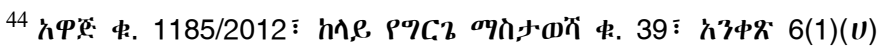




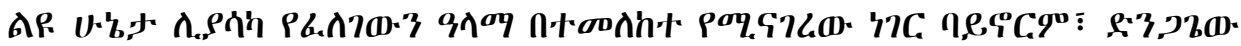

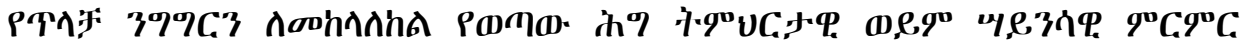

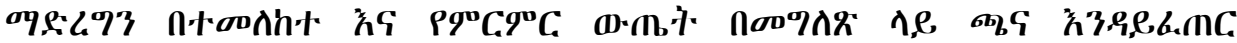

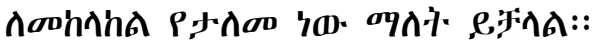

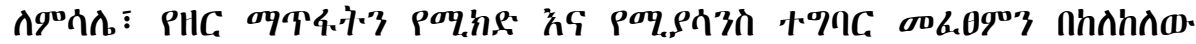

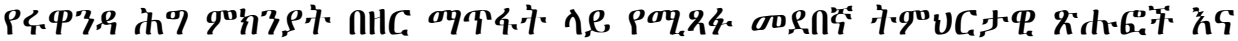

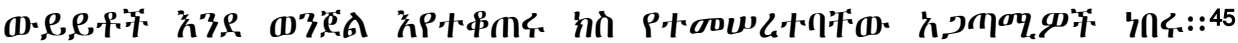

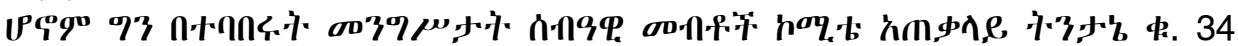

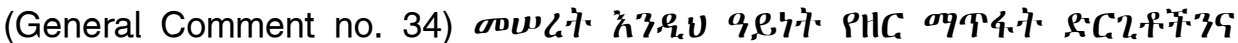

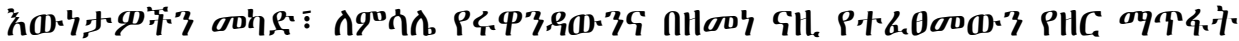

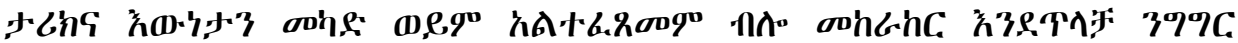

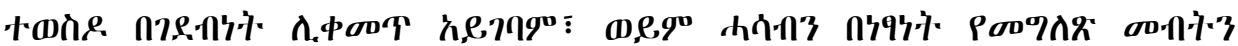

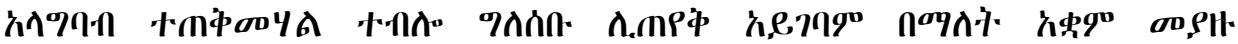

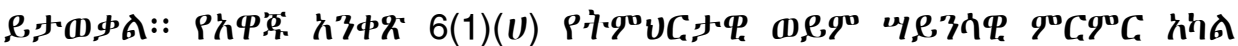

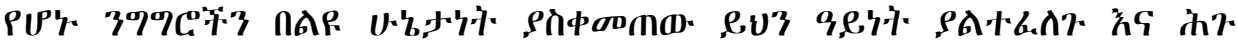

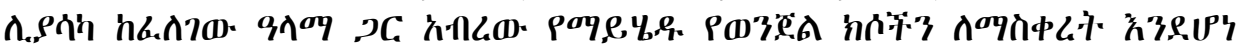
onLe't ,

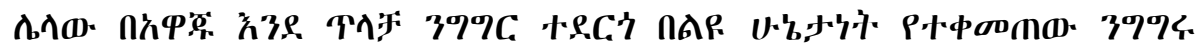

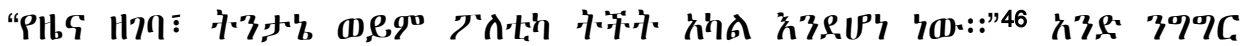

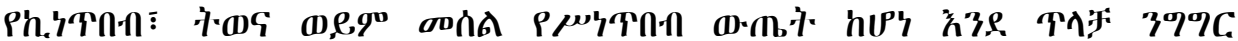
h,

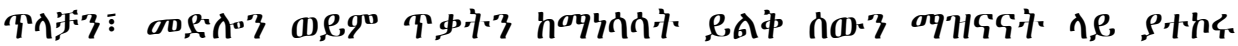

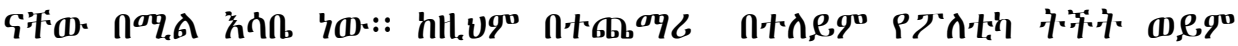

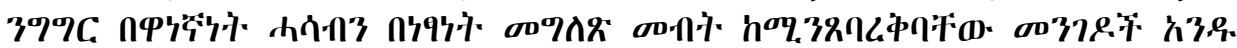

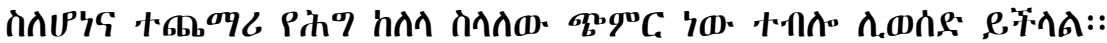

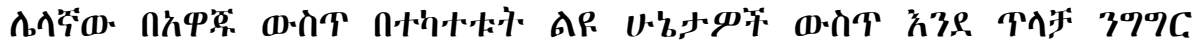
ڤ

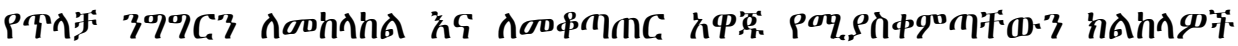

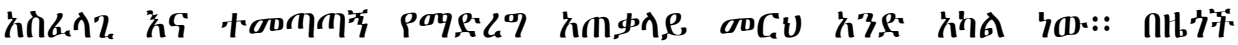
P当,

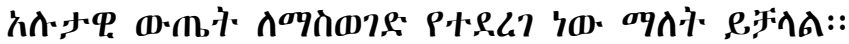

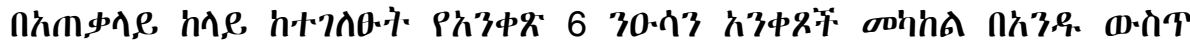

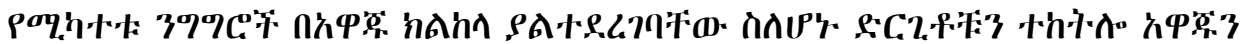

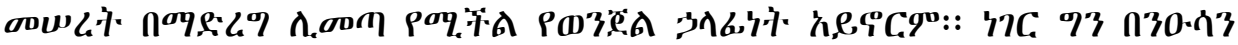

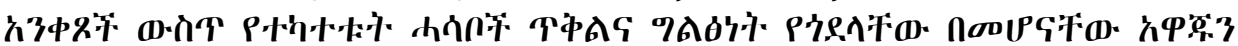

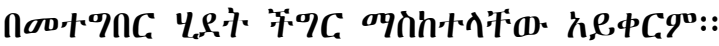

\footnotetext{
${ }^{45}$ Law no. 59/2018 of $22^{\text {nd }}$ August 2018 on the crime of Genocide ideology and related

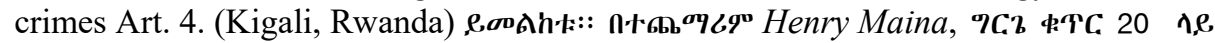
eorint::

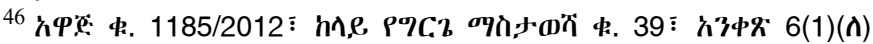

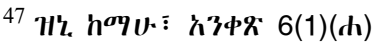

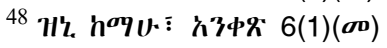


Freedom of Expression and Hate Speech in Ethiopia: Observations (in Amharic) 217

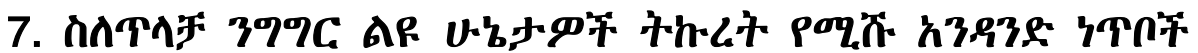

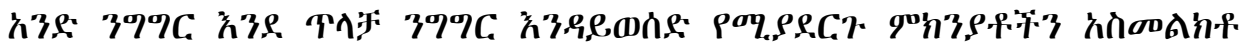

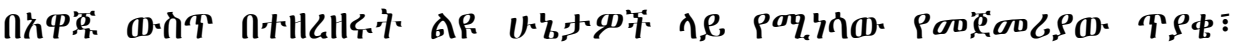

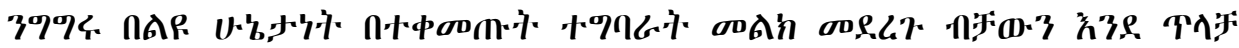
39\%С औ

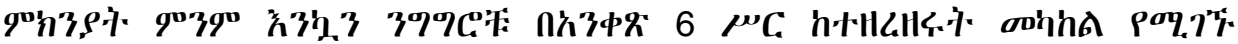

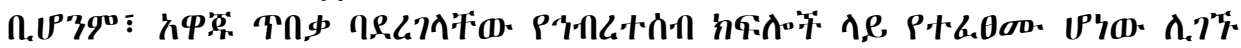
e?तn::

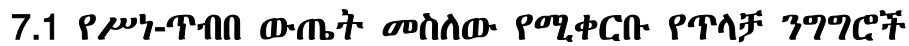

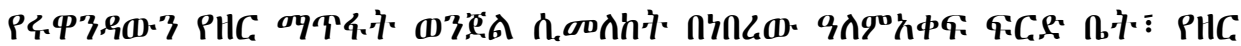

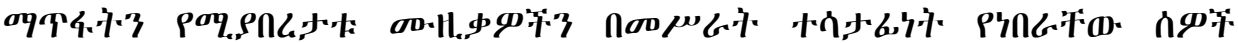

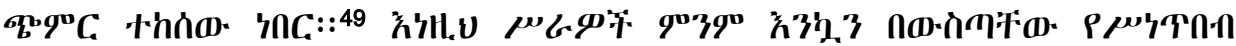

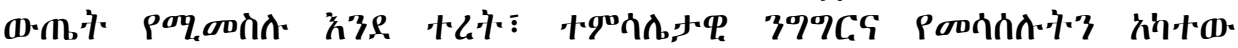

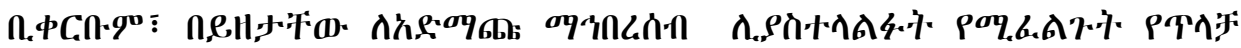

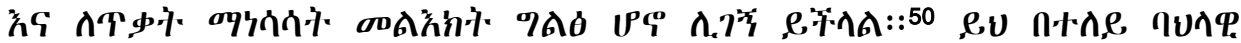

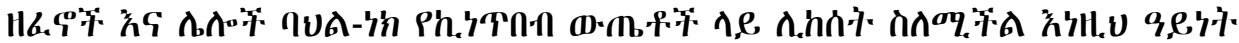
w

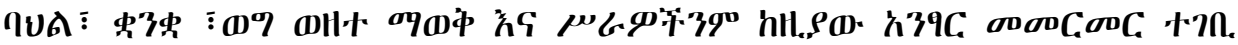

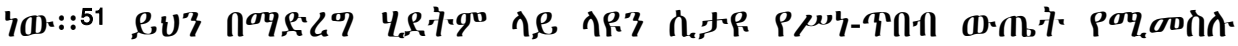
w

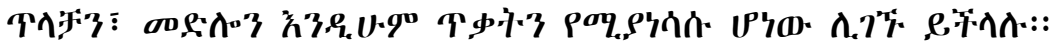

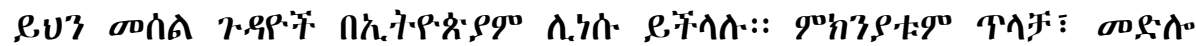

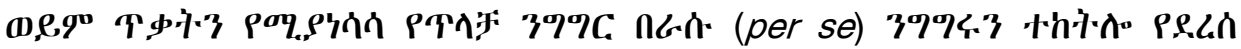

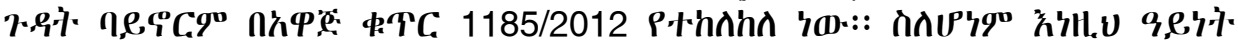

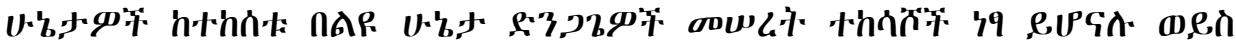

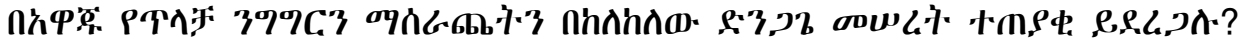

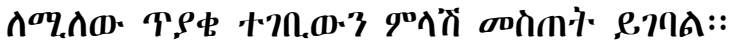

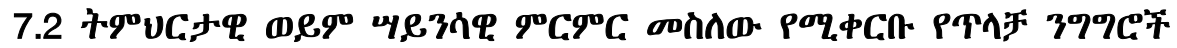

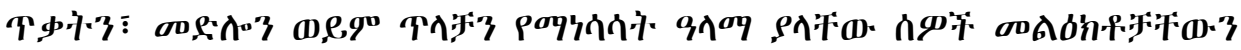

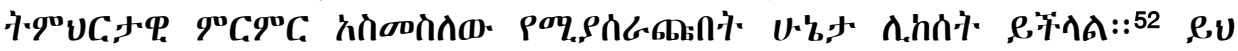

\footnotetext{
${ }^{49}$ Comparative Hate Speech Law: Annexture, Research prepared for the Legal Resources Centre, South Africa $\bar{\Sigma}$ (March 2012) $\bar{\vdots}$ Oxford Pro Bono Publico

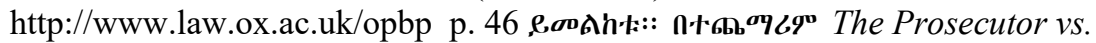
Ferdinand Nahimana, Jean-Bosco Barayagwiza and Hassan Ngeze (Appeal Judgment) ICTR-99-52-A, International Criminal Tribunal for Rwanda (ICTR), 28 november 2007 ,

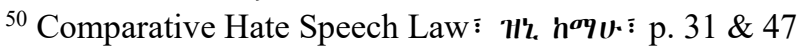

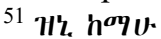

${ }^{52} \mathrm{HI}^{2} \cdot \mathrm{h}^{\boldsymbol{0}} \mathrm{YU}$.
} 


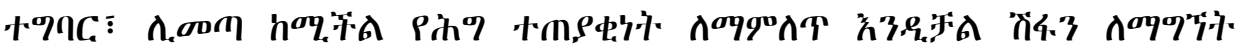

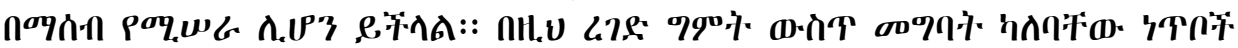

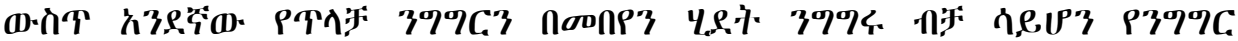

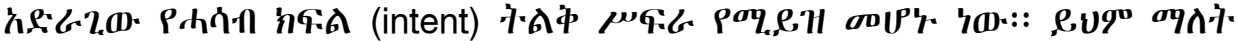

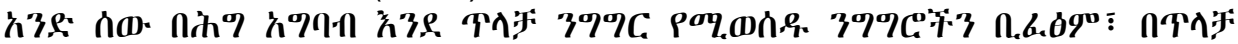

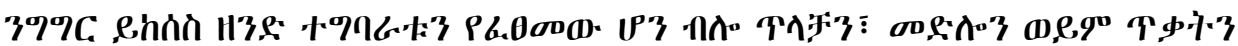
ח

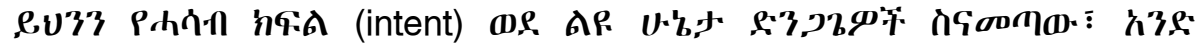

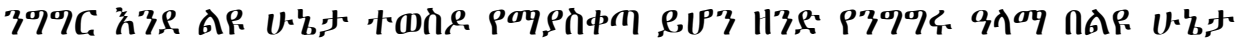

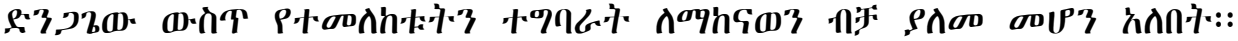

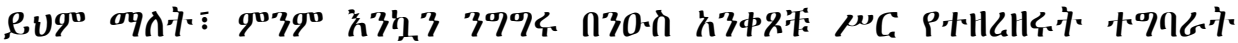

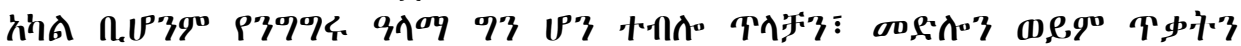

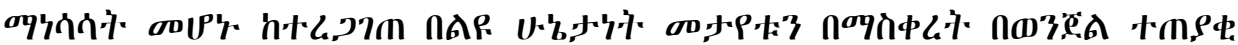

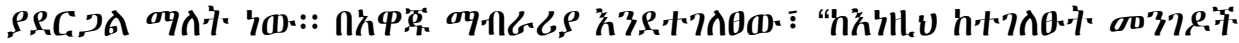

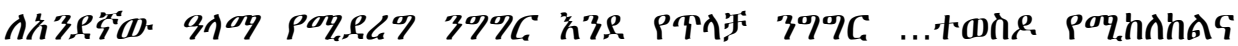

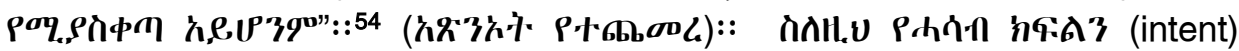

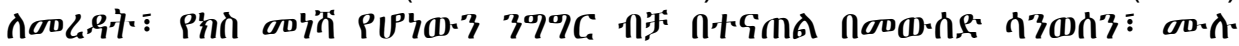

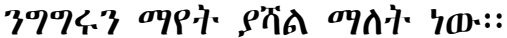

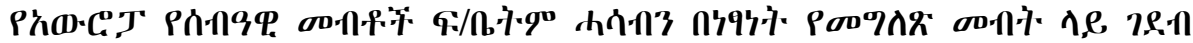

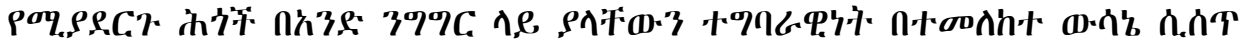

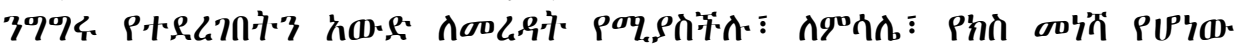

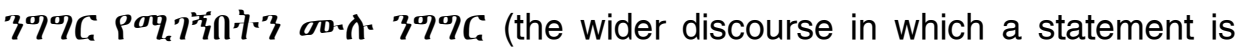

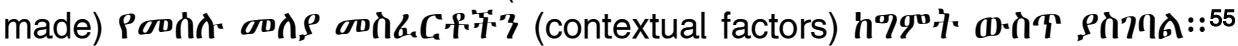

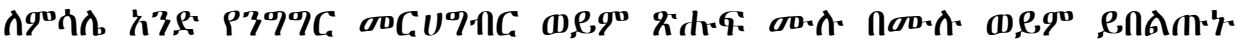

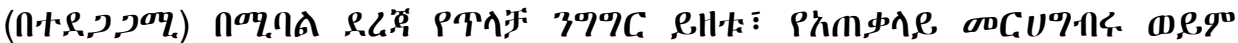

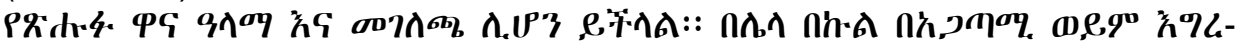

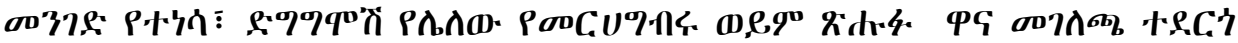

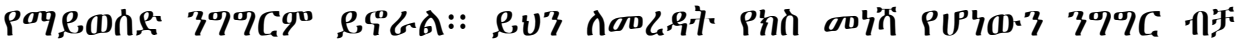

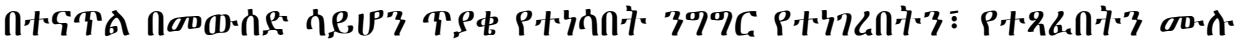

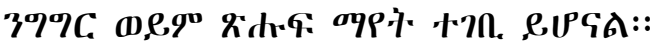

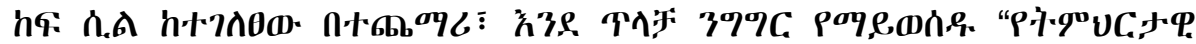

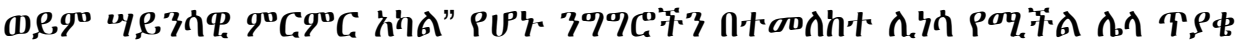

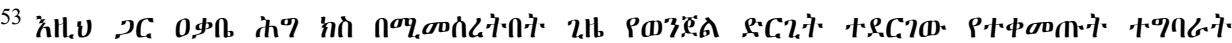

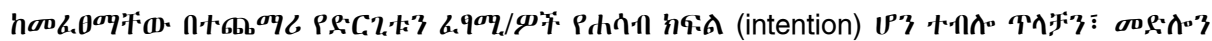

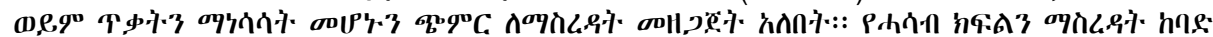

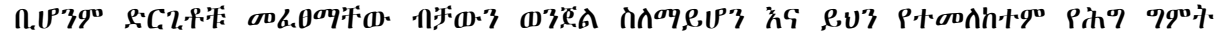

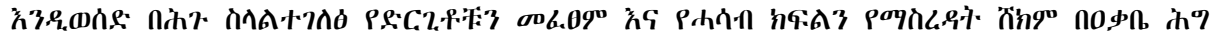

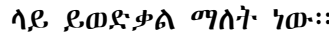

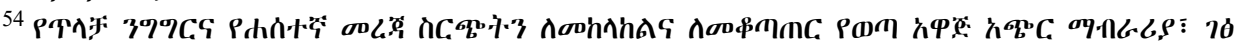
3

55 Therese E. \& Simon L., Free speech or hate speech? A legal analysis of the discourse about Roma on Twitter, Information \& Communications Technology Law, p. 2 available at https://www.tandfonline.com/doi/full/10.1080/13600834.2018.1494415
} 
h九: :

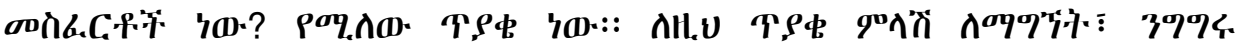
Pीत

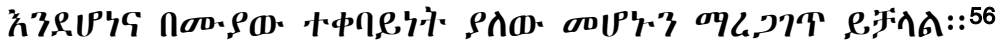

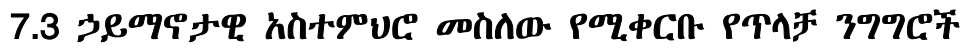

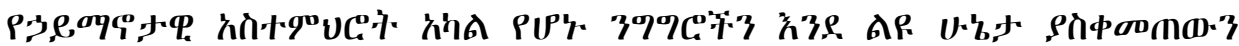

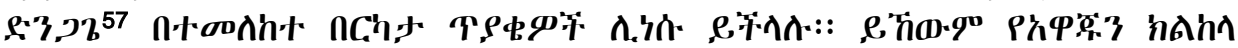

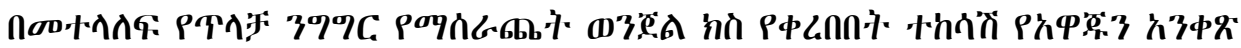

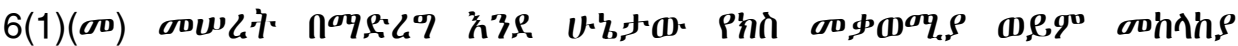

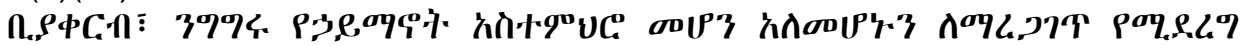

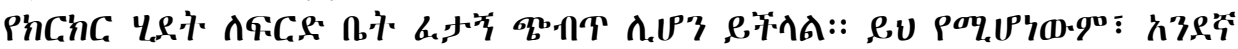

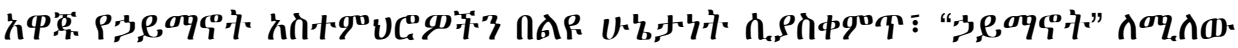

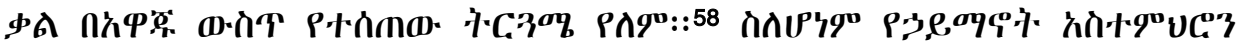

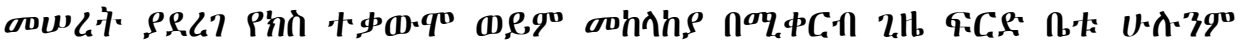

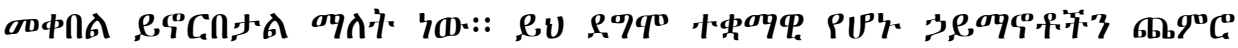
n

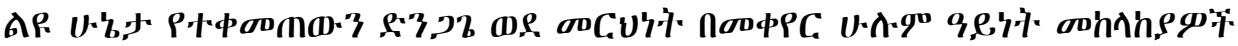

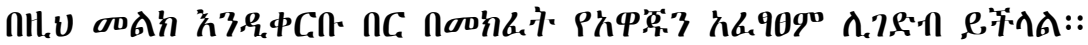

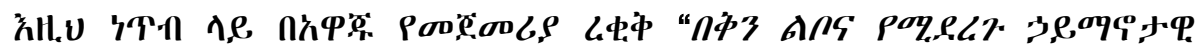

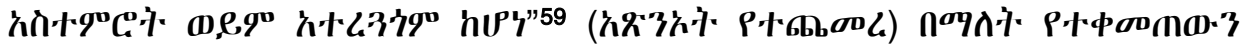

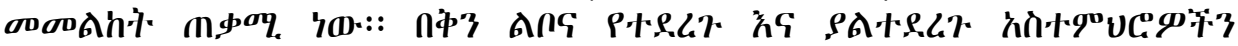

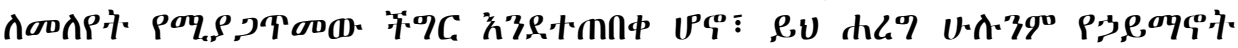

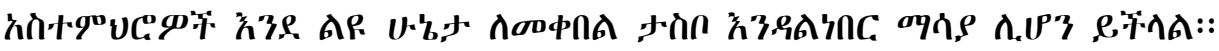

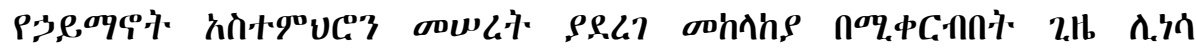

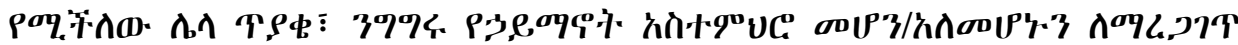

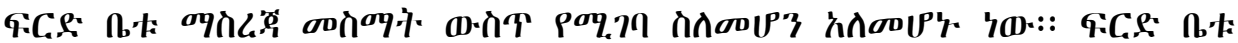

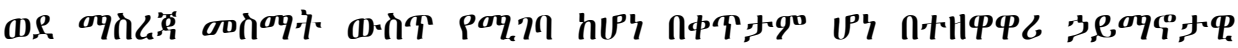

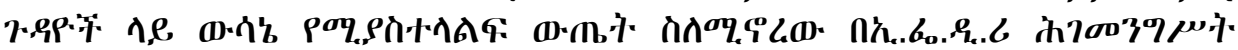

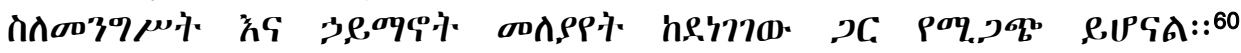

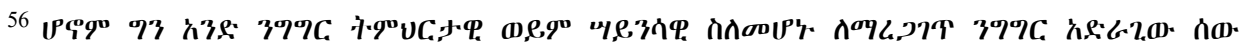

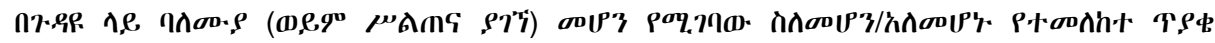
ח.'ל ,

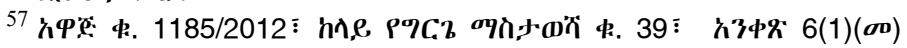

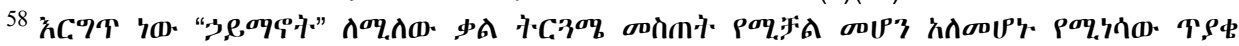

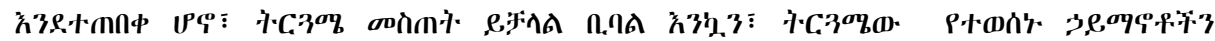

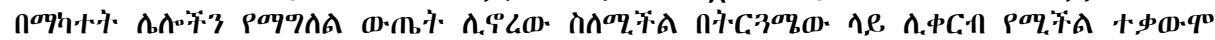

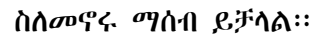

59 חל, T.8.

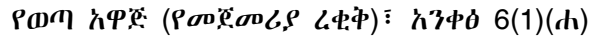

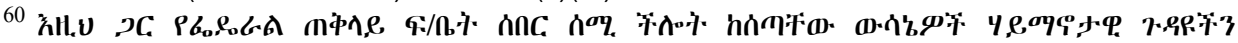

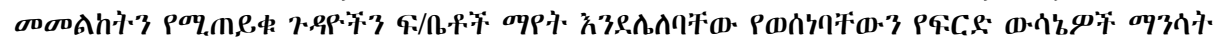




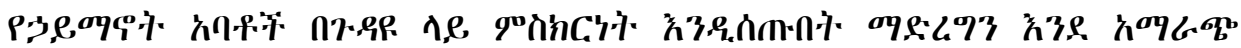

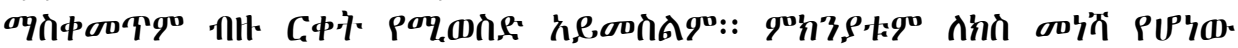

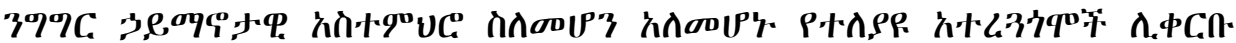

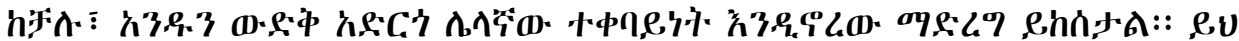

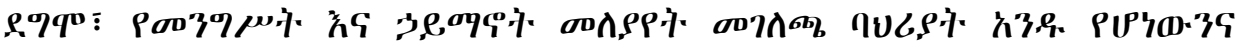

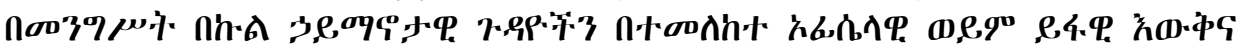

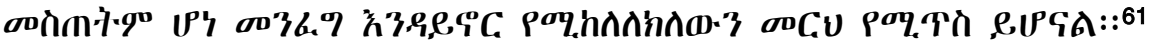

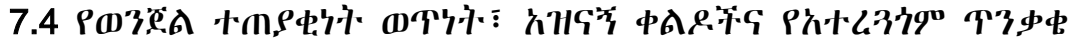

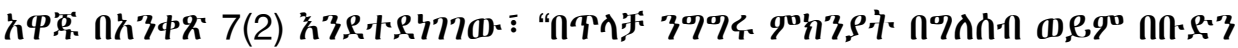

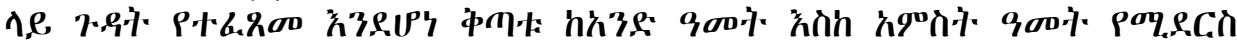

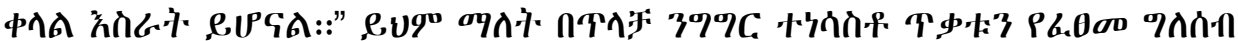

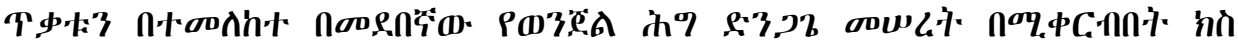

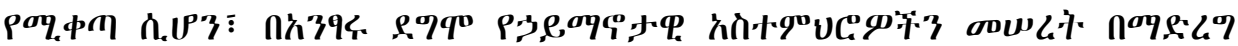

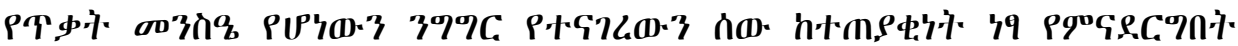

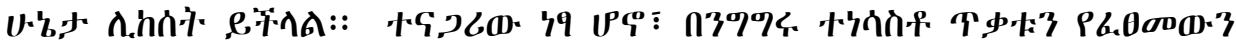
\%तก' อกล:

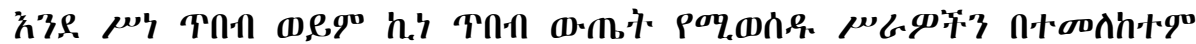

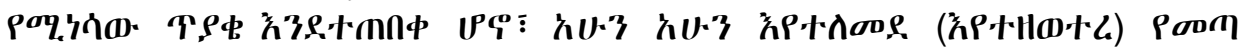

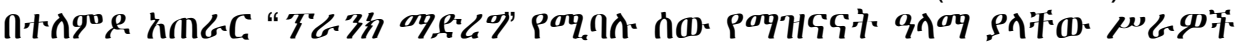

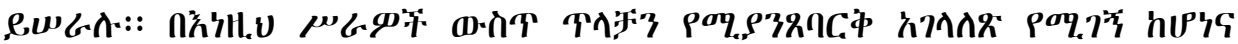

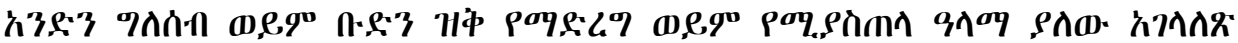

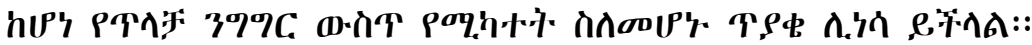

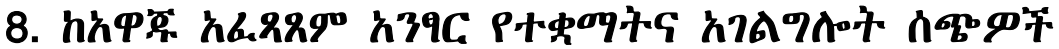 316427}

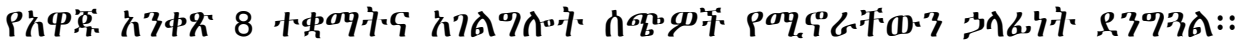

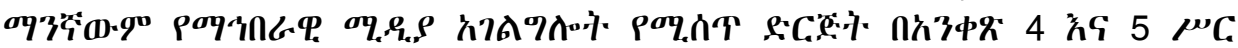

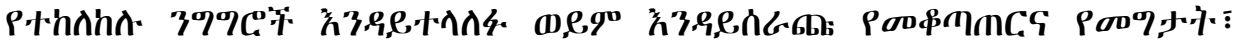

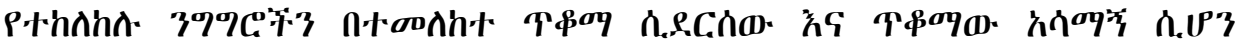

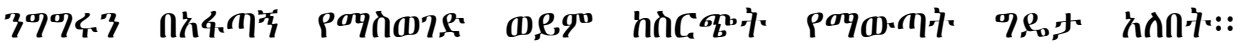

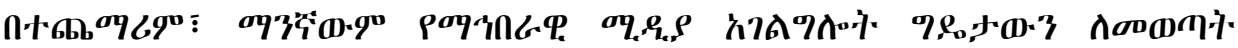

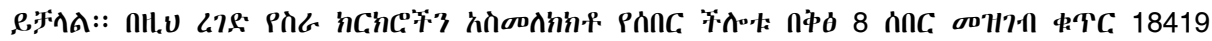

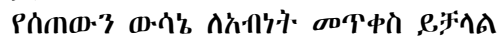

${ }^{61}$ Secularism, among other things, prohibits a state from indulging in the promotion of religious views. (See Charles Taylor, The Meaning of Secularism, at 23, available at: http://iasc-culture.org/THR/archives/Fall2010/Taylor_lo.pdf; see also, Abdelwahab El- Affendi, Beyond Secularism: Sectarian Conflict and the Resilience Challenge for the African State, at.8, available at:

https://www.africaportal.org/dspace/articles/beyond-secularism-sectarian-conflictand-resilience-challenge-african-state 


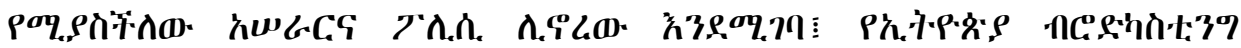
१人 ๆ

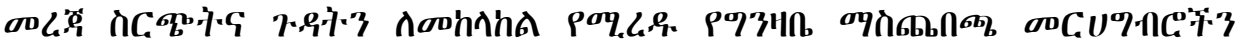

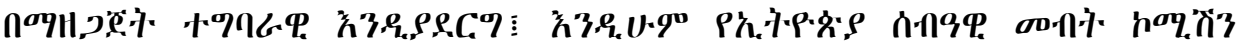

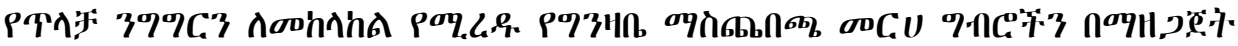

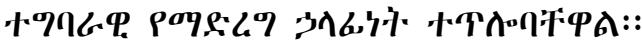

hH. ก ก.6.

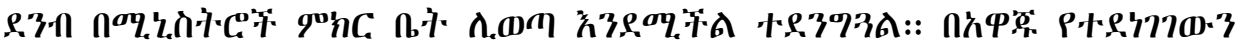
ๆ

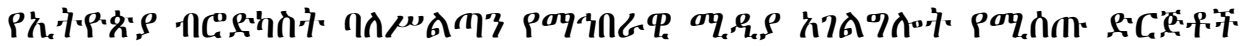

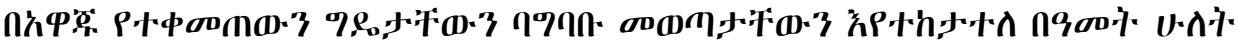

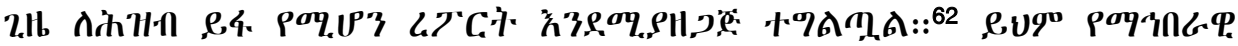

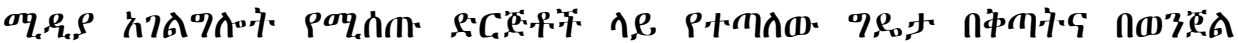

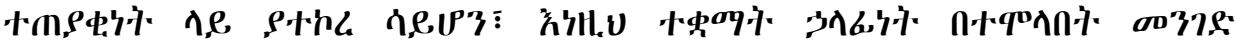
え3. rm,

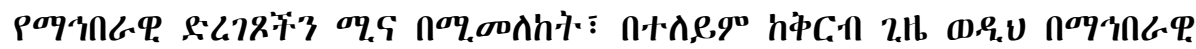

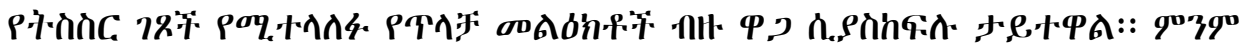

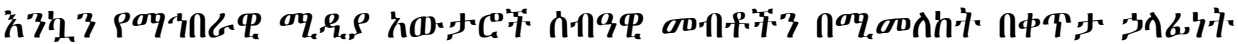

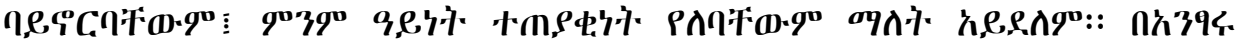

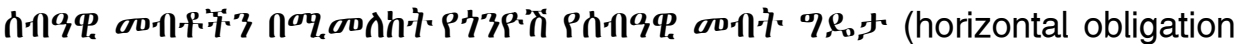

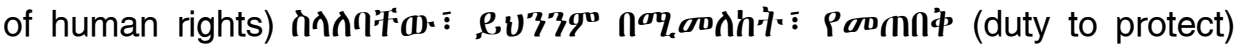

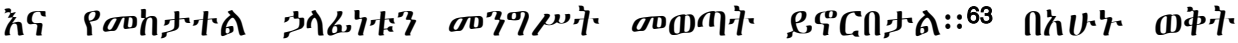

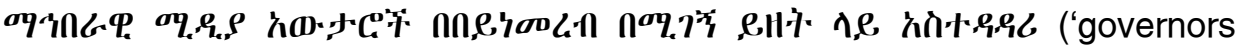

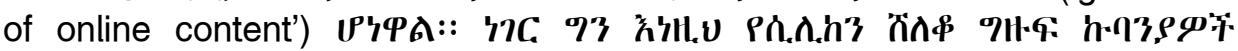

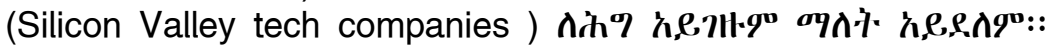

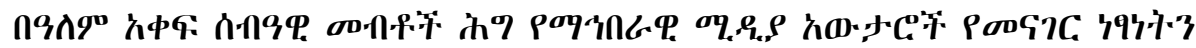

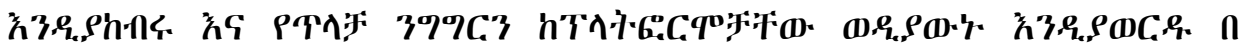

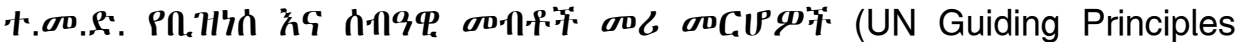

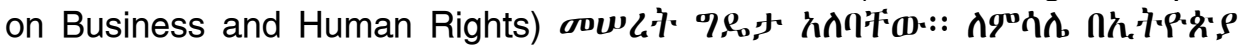

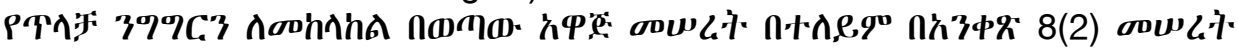

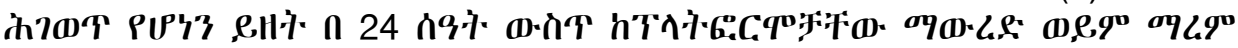

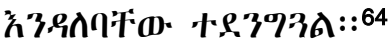

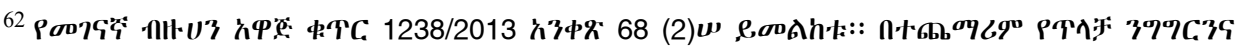

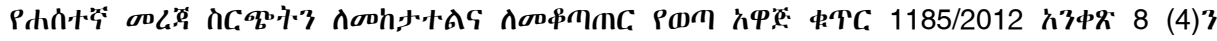
eoshht::

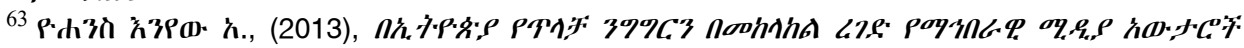
oq, Abyssinia Law Blog, p. 10

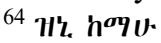




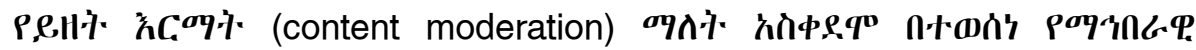

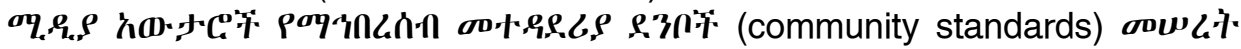
ל3.8.

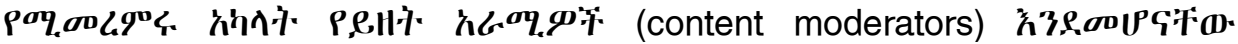
P,H' T⿱中⿰㇀丶㇀

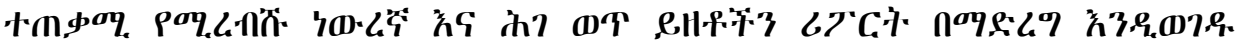

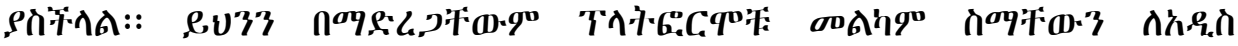

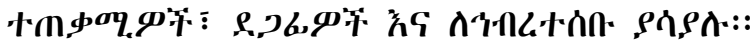

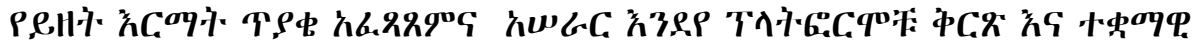

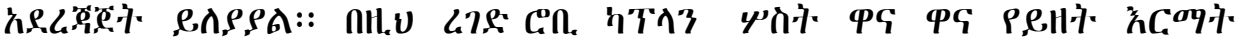

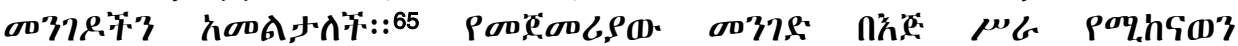

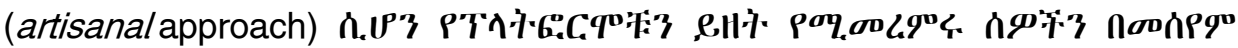

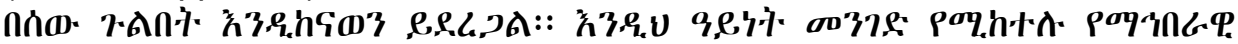
oq.

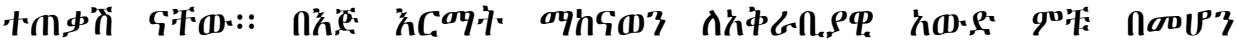

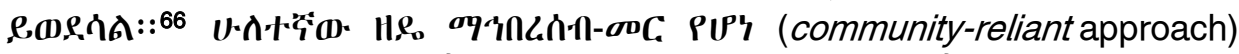

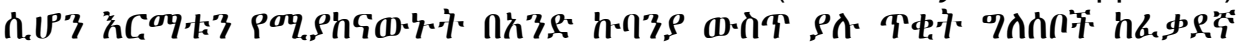

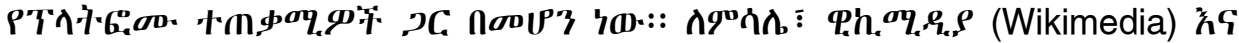

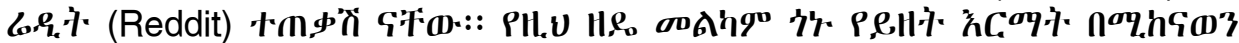

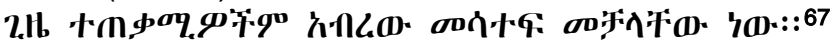

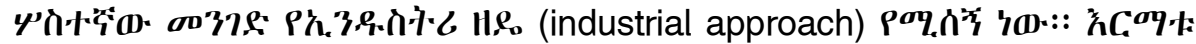

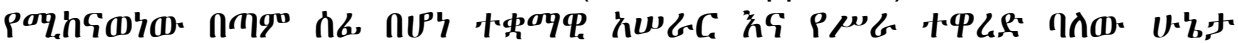

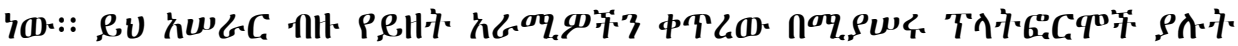

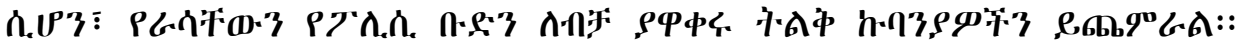

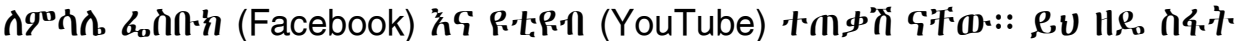

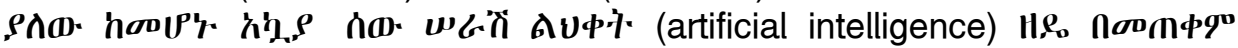

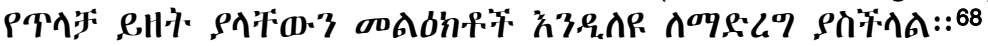

Poquld. oq.

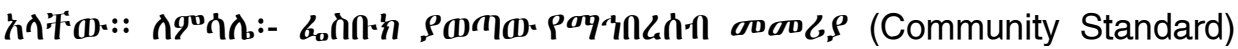

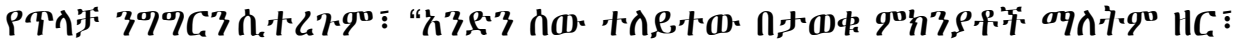
中ก9"

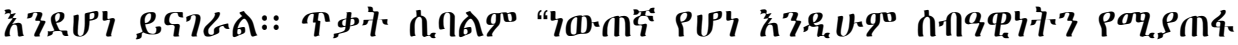

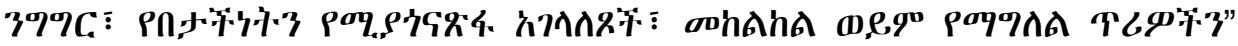
อดถ० G.A::

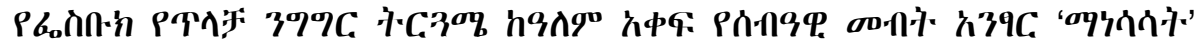

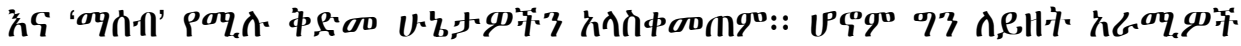

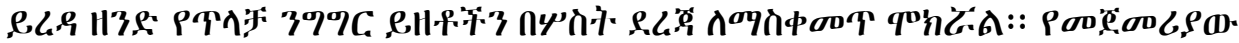

\footnotetext{
65 Hל. $\boldsymbol{h}^{\text {oq }}$.

66 H', h⿻甲一

67 Hל. h⿻甲

68 H'. hั9v.
} 


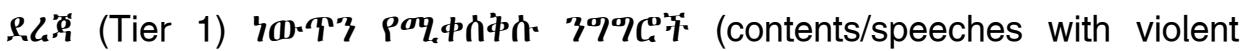

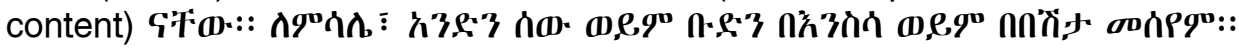

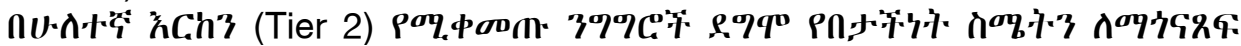

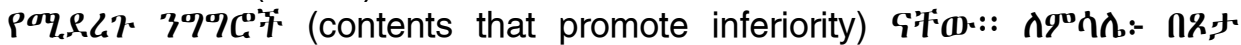

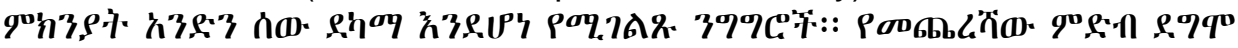

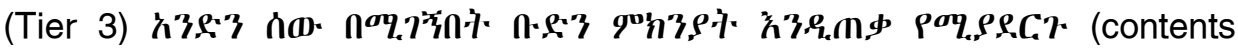

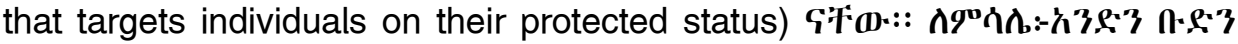

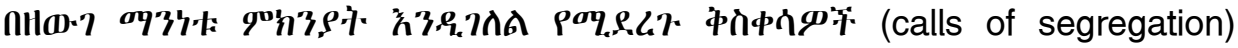

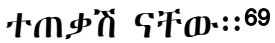

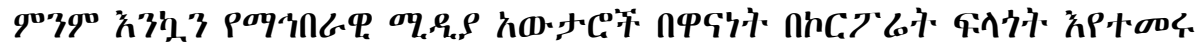

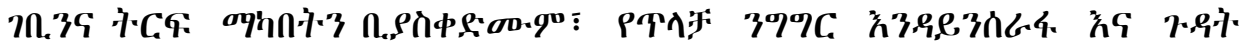

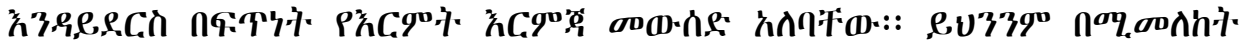

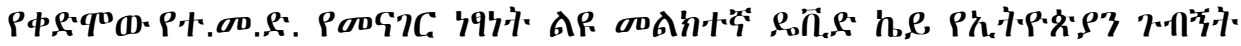

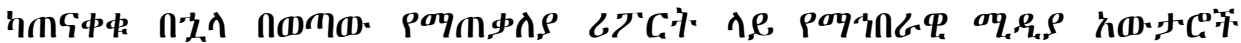

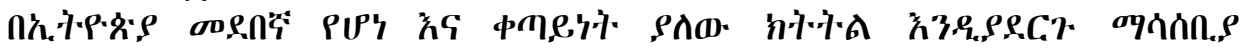
QC. $, A:: 70$

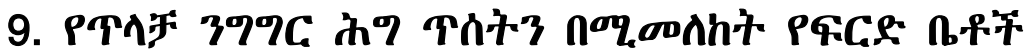

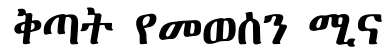

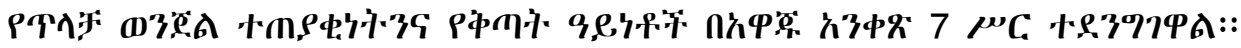

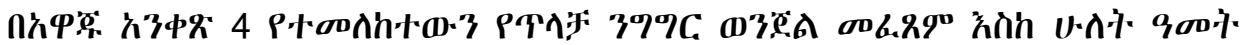

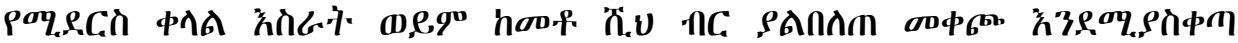

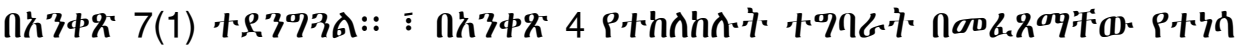

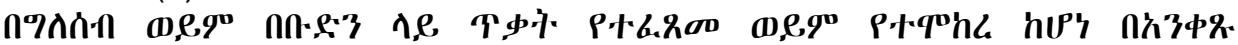

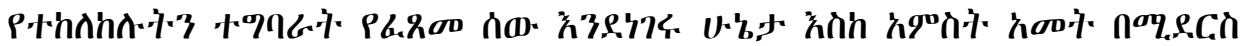

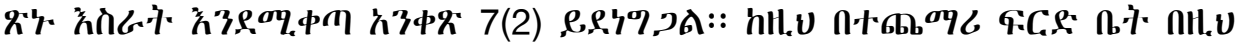

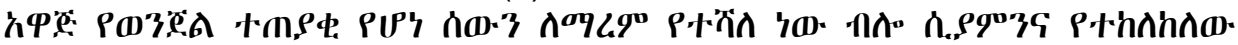

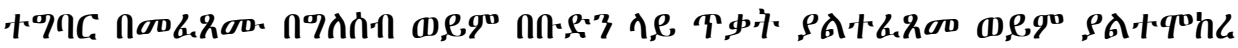
hษ"

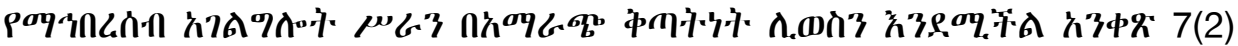
Q.R.'T\%::

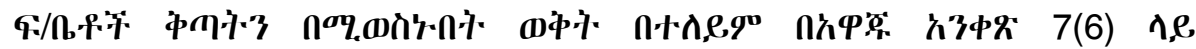

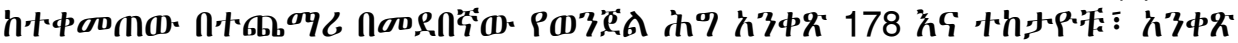

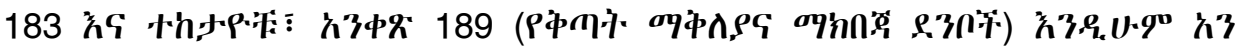

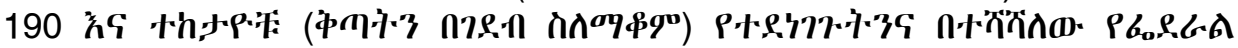

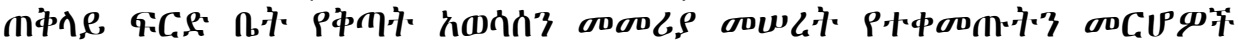

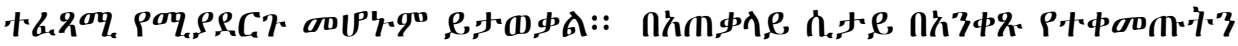

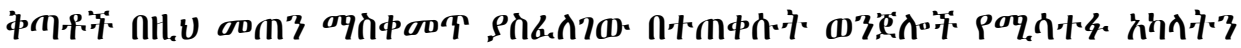

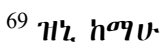

70 H'. h⿻甲
} 


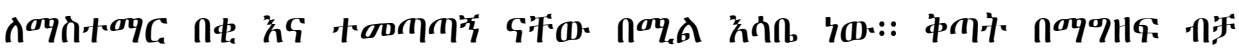

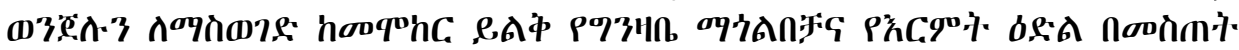

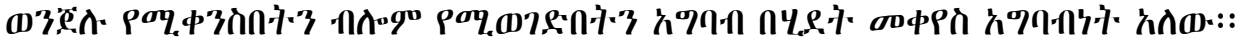

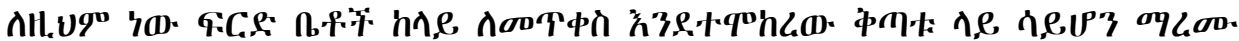

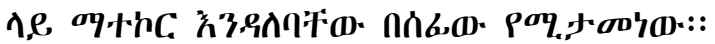

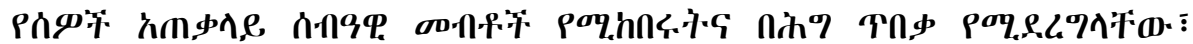

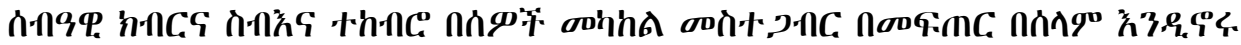

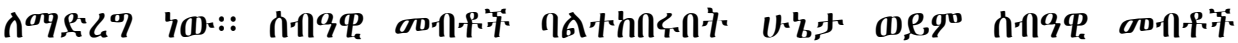

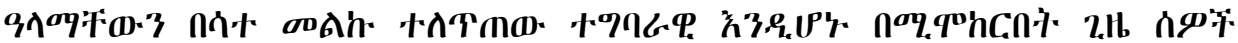

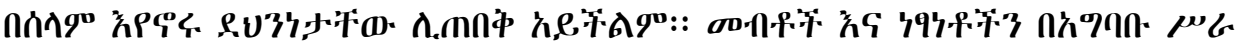

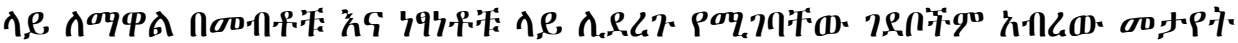

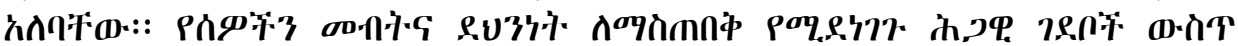

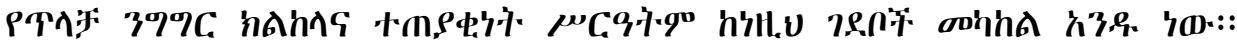

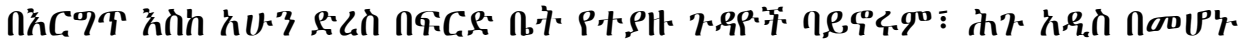

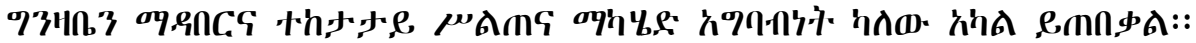

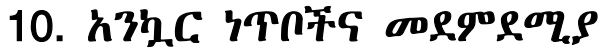

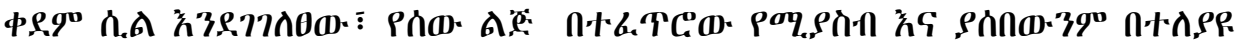

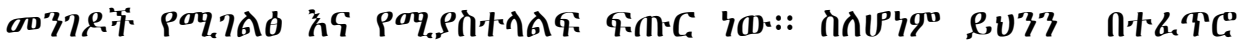

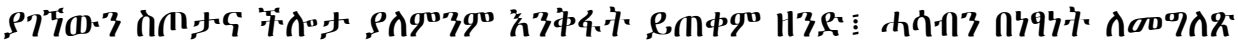

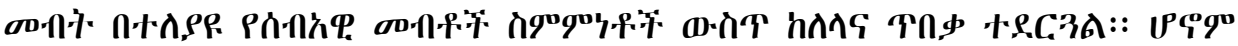

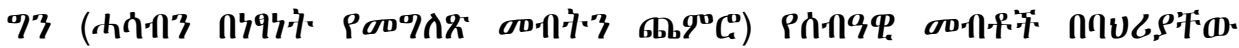

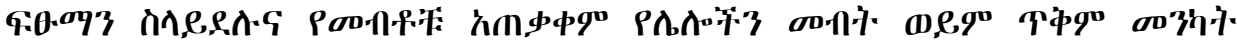

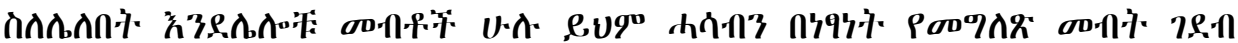

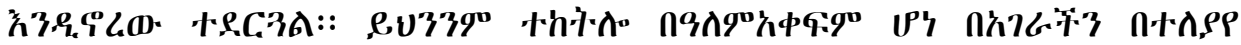

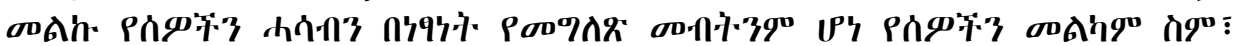

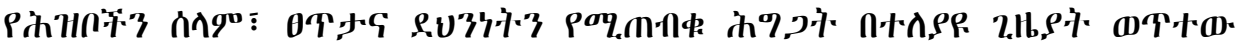

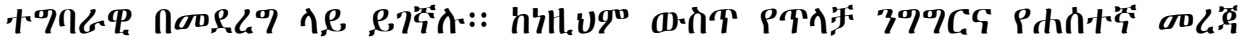

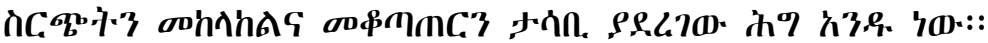

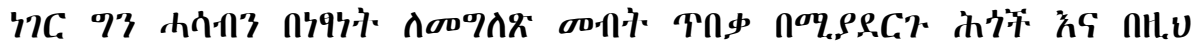

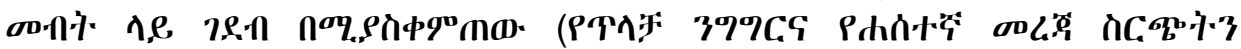

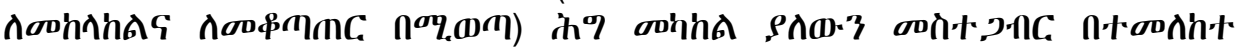

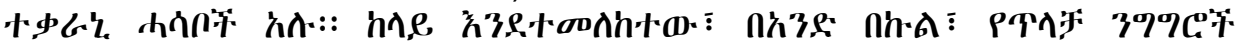

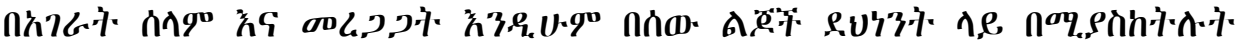

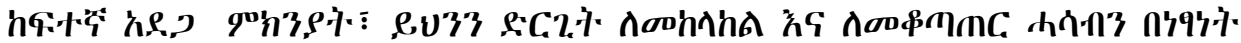

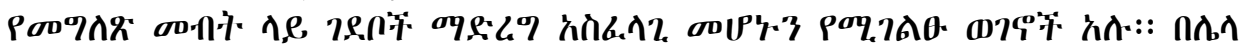

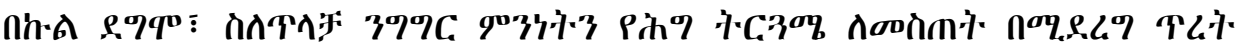

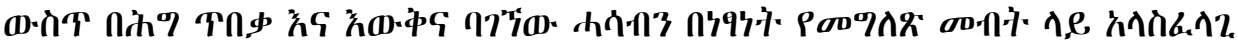

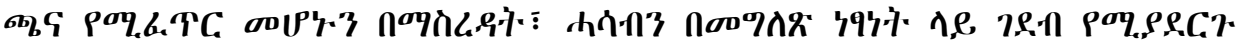

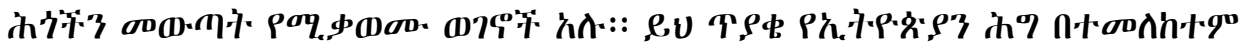

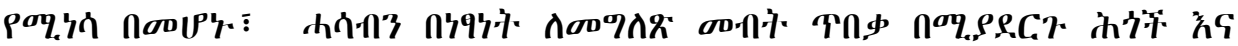

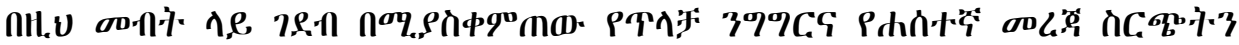

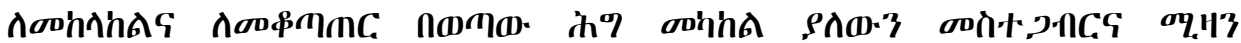

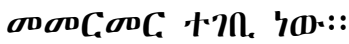




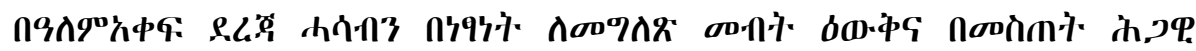

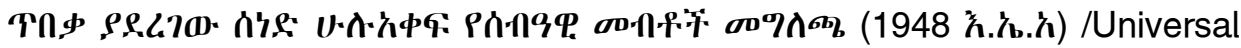

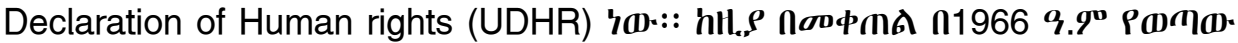

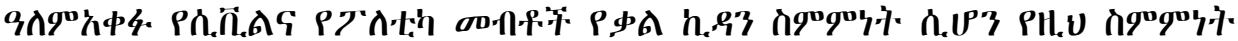

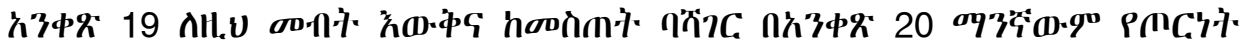

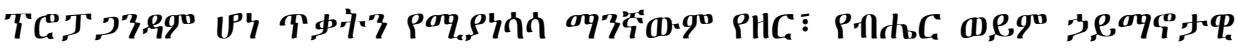

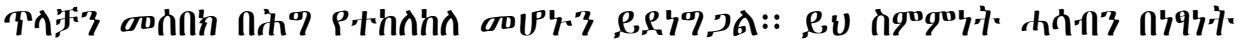

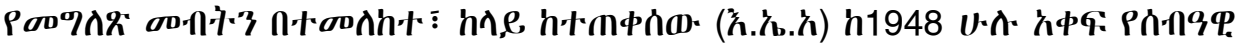

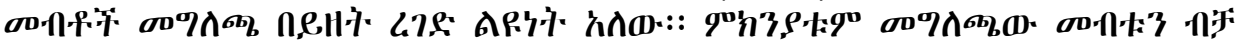

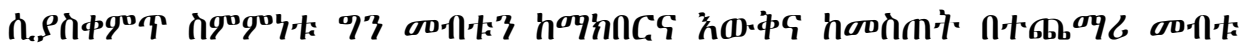

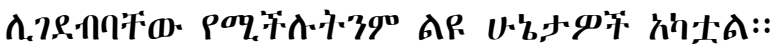

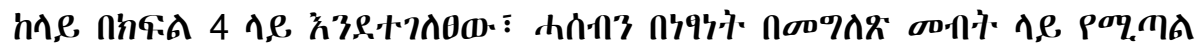

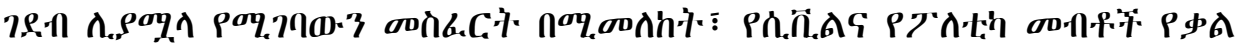

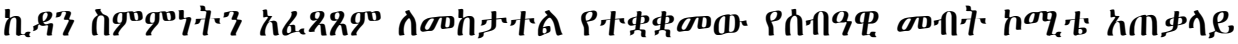

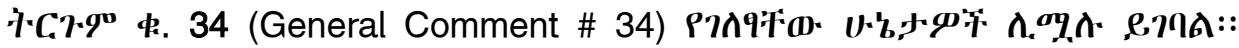

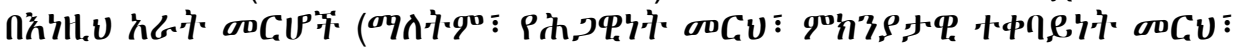

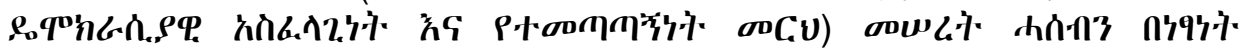

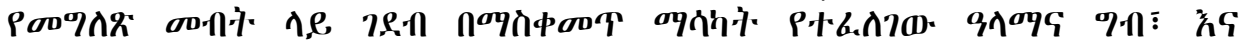

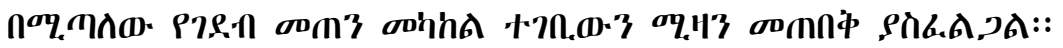

01987 9.90 ө.8.

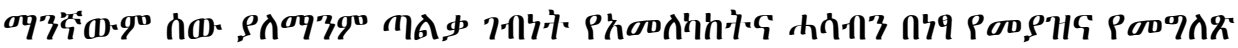

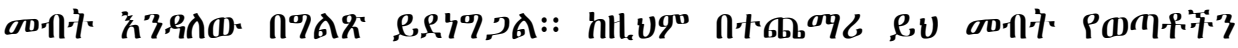

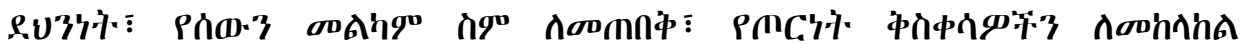

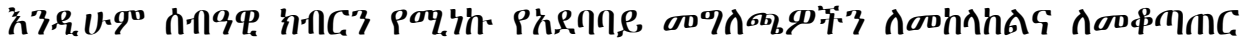

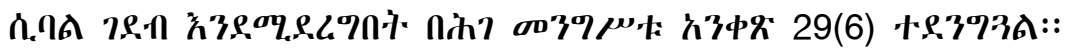

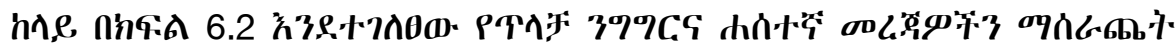

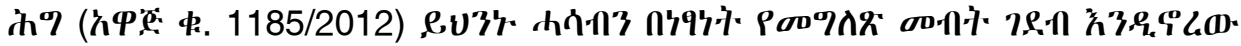

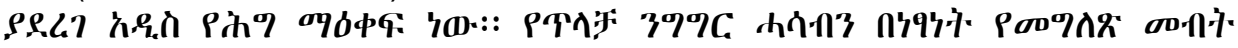

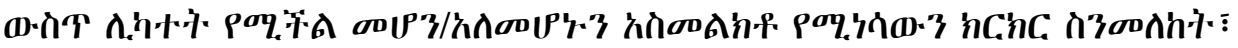

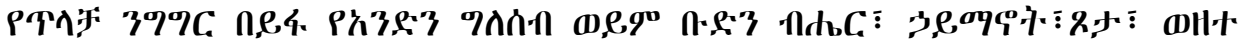

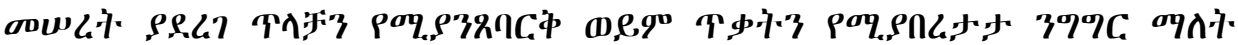

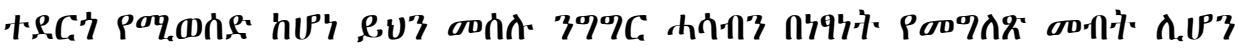

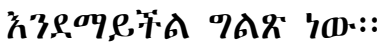

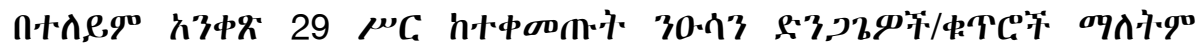

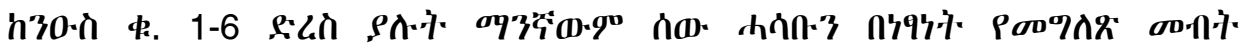

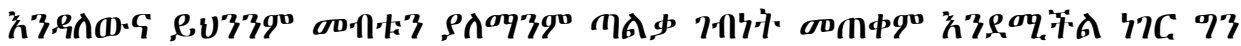

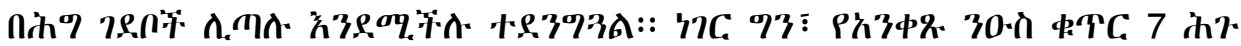

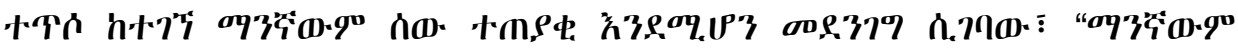

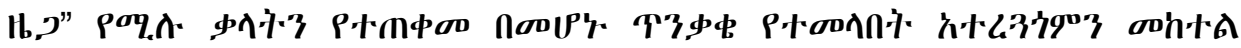

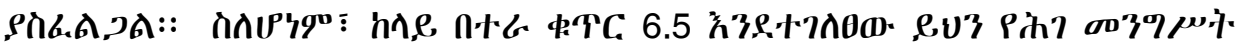

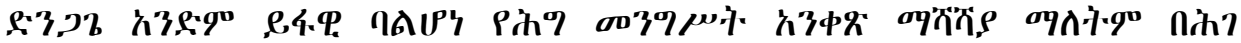

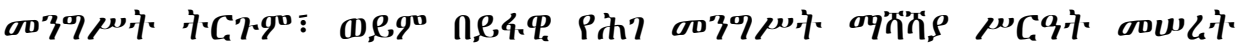




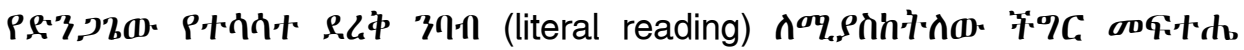

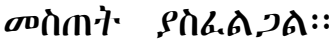

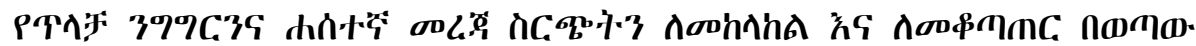

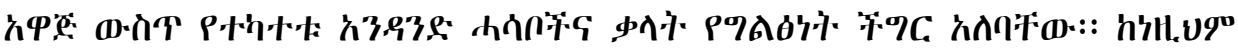

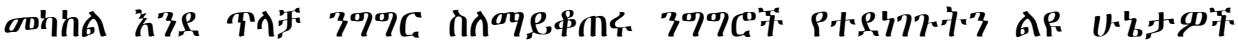

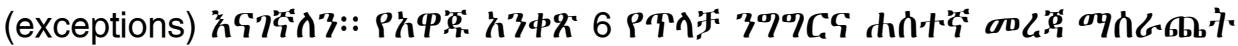

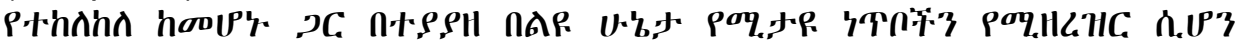

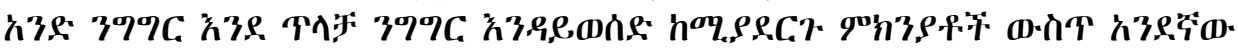

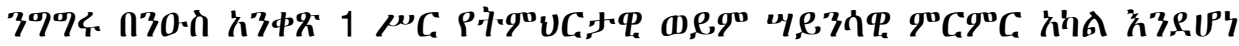
10)::"

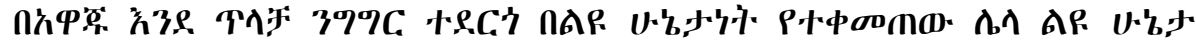

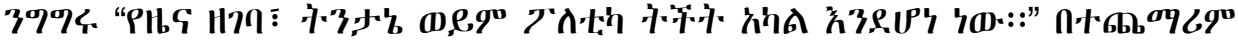

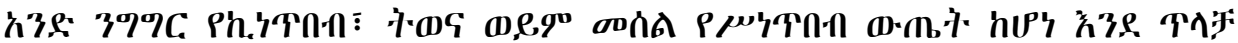

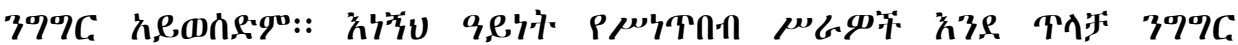
poqedn

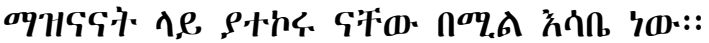

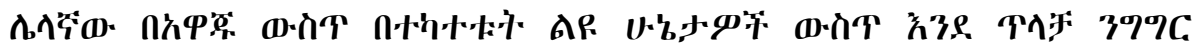
ह3 久中杲 PoY,

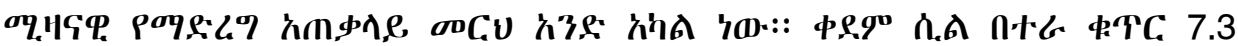

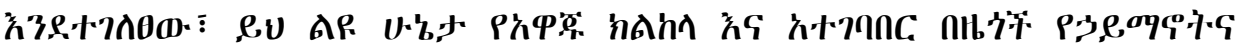

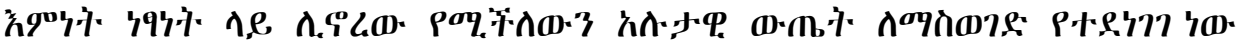
ond

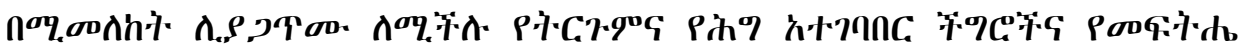

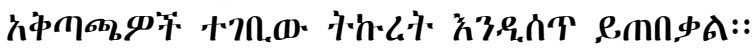

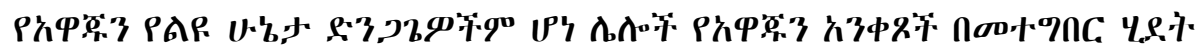

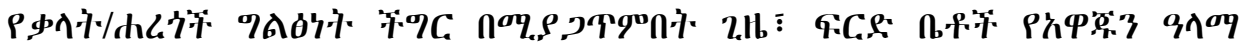
ח.

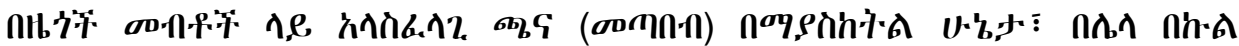

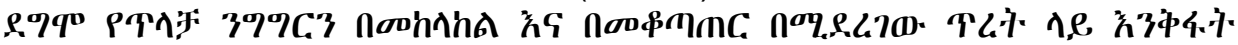

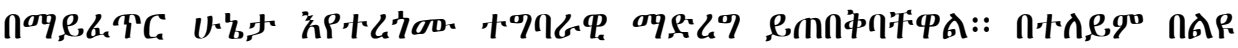

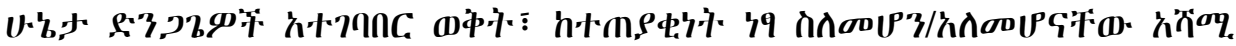

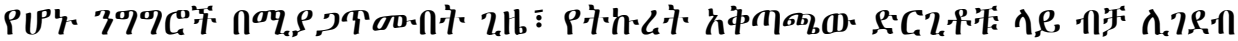
ל, ל799:: U.b.

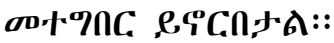

